\title{
Where Carbon Goes When Water Flows: Carbon Cycling across the Aquatic Continuum
}

\author{
Nicholas D. Ward ${ }^{1,2,3 *}$, Thomas S. Bianchi ${ }^{3}$, Patricia M. Medeiros ${ }^{4}$, Michael Seidel ${ }^{5}$, \\ Jeffrey E. Richey ${ }^{6}$, Richard G. Keil ${ }^{6}$ and Henrique O. Sawakuchi ${ }^{7}$
}

${ }^{1}$ Marine Sciences Laboratory, Pacific Northwest National Laboratory, Sequim, WA, USA, ${ }^{2}$ Whitney Laboratory for Marine Bioscience, University of Florida (UF), St. Augustine, FL, USA, ${ }^{3}$ Department of Geological Sciences, University of Florida (UF), Gainesville, FL, USA, ${ }^{4}$ Department of Marine Sciences, University of Georgia, Athens, GA, USA, ${ }^{5}$ Research Group for Marine Geochemistry (Intitute for Cemistry and Biology of the Marine Environment (ICBM)- Max Planck Institue (MPI) Bridging Group), Institute for Chemistry and Biology of the Marine Environment, Carl von Ossietzky University of Oldenburg, Oldenburg, Germany, ${ }^{6}$ School of Oceanography, University of Washington, Seattle, WA, USA, ${ }^{7}$ Centro de Energia Nuclear na Agricultura, Universidade de São Paulo (USP), Piracicaba, Brazil

\section{OPEN ACCESS}

Edited by:

Eric 'Pieter Achterberg,

GEOMAR Helmholtz Centre for Ocean

Research Kiel (HZ), Germany

Reviewed by:

Martin Johnson,

University of East Anglia (UEA), UK

Christian Lønborg,

Australian Institute of Marine Science,

Australia

George Andrew Wolff,

University of Liverpool, UK

*Correspondence:

Nicholas D. Ward nickdward@gmail.com

Specialty section:

This article was submitted to Marine Biogeochemistry,

a section of the journal

Frontiers in Marine Science

Received: 22 September 2016 Accepted: 09 January 2017 Published: 31 January 2017

Citation:

Ward ND, Bianchi TS, Medeiros PM, Seidel M, Richey JE, Keil RG and Sawakuchi HO (2017) Where Carbon Goes When Water Flows: Carbon

Cycling across the Aquatic Continuum. Front. Mar. Sci. 4:7. doi: 10.3389/fmars.2017.00007
The purpose of this review is to highlight progress in unraveling carbon cycling dynamics across the continuum of landscapes, inland waters, coastal oceans, and the atmosphere. Earth systems are intimately interconnected, yet most biogeochemical studies focus on specific components in isolation. The movement of water drives the carbon cycle, and, as such, inland waters provide a critical intersection between terrestrial and marine biospheres. Inland, estuarine, and coastal waters are well studied in regions near centers of human population in the Northern hemisphere. However, many of the world's large river systems and their marine receiving waters remain poorly characterized, particularly in the tropics, which contribute to a disproportionately large fraction of the transformation of terrestrial organic matter to carbon dioxide, and the Arctic, where positive feedback mechanisms are likely to amplify global climate change. There are large gaps in current coverage of environmental observations along the aquatic continuum. For example, tidally-influenced reaches of major rivers and near-shore coastal regions around river plumes are often left out of carbon budgets due to a combination of methodological constraints and poor data coverage. We suggest that closing these gaps could potentially alter global estimates of $\mathrm{CO}_{2}$ outgassing from surface waters to the atmosphere by several-fold. Finally, in order to identify and constrain/embrace uncertainties in global carbon budget estimations it is important that we further adopt statistical and modeling approaches that have become well-established in the fields of oceanography and paleoclimatology, for example.

Keywords: terrestrial, riverine, estuarine, marine, organic, carbon, ecosystem

\section{INTRODUCTION}

Water acts as the driving force moving biogeochemical constituents through earth reservoirs and across the continuum of the atmosphere, soils, inland waters, oceans, and sediments (Figure 1; Cole et al., 2007; Tranvik et al., 2009). Biological and physical mechanisms (e.g., weathering, burning, and photo-oxidation) transform organic carbon-containing molecules along their journey, but the fate of $\mathrm{OM}$ is not chemically intrinsic (i.e., predetermined based on chemical structure) as often 
assumed (Zonneveld et al., 2010). Although physical processes such as burning can render OM less bioavailable (Baldock et al., 2004), nearly all types of organic molecules (e.g., rock, petroleum, combustion, and plant-derived) are bioavailable in the appropriate setting (Petsch et al., 2001; Raghukumar et al., 2001; Ward et al., 2013; Myers-Pigg et al., 2015).

Rates of OM decomposition in both soils (Schmidt et al., 2011) and aquatic settings (Dittmar, 2015) depend on a suite of factors including microbial community composition, redox state, and sorption/desorption of organic molecules to particles. Organic matter-mineral associations are an important factor in the selective preservation of organic molecules along with ambient oxygen levels (Keil and Mayer, 2014). Inland waters are recognized as efficient bioreactors where terrestrial OM is rapidly decomposed due to ideal conditions for microbial metabolism (Richey et al., 2002). As such, OM is relatively short-lived in inland waters with a mean residence time of roughly $2.5 \pm 4.7$ years, compared to centennial to millennial-scale residence times in soils, oceans, and sediments (Catalán et al., 2016).

Interactions between microbes and $\mathrm{OM}$ that occur along ecosystem transitions have not yet been adequately quantified or incorporated into aquatic carbon budgets. For example, in the Amazon River the breakdown of vascular plant-derived $\mathrm{OM}$ to $\mathrm{CO}_{2}$ is enhanced by as much as 6-fold when algaerich tributaries mix with the sediment and terrestrially-derived OM-rich main channel (Ward et al., 2016). This phenomenon, referred to as the priming effect, has been well studied in soils (Löhnis, 1926; Kuzyakov et al., 2000), but has only recently received attention from aquatic scientists (Aller et al., 1996; Guenet et al., 2014; Bianchi et al., 2015). It is hypothesized that this process plays an important role on OM decomposition across a wide range of settings such as estuaries (Steen et al., 2015), coastal oceans, river plumes (Aller et al., 1996), natural and manmade reservoirs, the hyporheic zone, and lower rivers (Bianchi, 2011). However, a consensus has not been reached with other observations of no priming and negative priming across different aquatic environments (Gontikaki et al., 2013; Bengtsson et al., 2014; Catalán et al., 2015).

One difficulty in assessing the importance of processes occurring along ecotones such as priming is that there are so few studies evaluating systems over their full reach. The vast majority of scientific studies are limited in scope and only focus on a few questions or locations. Understanding global cycles requires more integrated and systemic studies. The Amazon River is one example of a system where considerable recent effort has been made to examine organic matter cycling from "source to sink." For example, Feng et al. (2016) evaluated changes in OM composition from Peruvian headwaters to marine sediments with comparisons to available data in the central reaches of the river. The lower reaches of the river, which represents $13 \%$ of the total basin area, have been unstudied until recently (Ward et al., 2015) and there has also been recent effort examining the evolution of $\mathrm{OM}$ and microbial communities from the river into the ocean plume (Medeiros et al., 2015a; Satinsky et al., 2015; Seidel et al., 2015a).

Consolidating an understanding of processes that occur along the aquatic continuum in the context of global carbon fluxes requires integrating lessons learned from micro/mesocosm scale experimentation and local, regional, and continental scale observations (i.e., Macrosystems Ecology; sensu Heffernan et al., 2014). Further, the effects of human alterations to the natural ecosystem processes are not well understood. For example, fossilfuel emissions and land use change have altered the natural cycling of carbon, and this influence is continuing to grow; global fossil-fuel emissions have increased by roughly 65\% from 1990 to 2014 (Le Quéré et al., 2015). Understanding how ecosystems will respond to enhanced greenhouse gas (GHG) levels in the atmosphere and how carbon is naturally cycled between earth systems is critical in constraining the extent to which terrestrial and aquatic biospheres can absorb and sequester anthropogenic emissions.

The purpose of this review is to evaluate current paradigms and gaps in our understanding of the transport and transformation of carbon constituents along the continuum of the atmosphere, the terrestrial biosphere, inland waters, estuaries, and coastal oceans. The open ocean is a central part of the global carbon cycle, but the considerable amount of work done in this setting merits its own review. Although the hydrologic cycle is a continuous and dynamic loop, for the sake of this review we will consider rainfall and the coastal ocean to be the starting and ending points of our discussion, respectively. We will describe the processes occurring along this continuum and end with a discussion on current estimates of carbon fluxes to/from each compartment.

\section{HYDROLOGIC AND BIOGEOCHEMICAL LINKAGES}

A watershed, as the landscape through which all waters flow from their highest source before draining naturally to the sea, is a fundamental organizing unit of the land surface. Water drives the biogeochemical dynamics described in this review (Figure 2). Rainfall washes out atmospheric particles and OM deposited or secreted from vegetation into the soils. This input together with plant material deposited in surface soils provides organic substrates that sustain a large variety of soil organisms. The infiltration of water into soils and movement of water over the landscape transports geochemical constituents vertically into groundwater and laterally into rivers and streams. However, the connection between above and below ground flow paths is sensitive to disruptions such as over-extraction of groundwater reserves, pollution of aquifers, or seawater intrusion due to sealevel rise. This section describes the mobilization and transport of carbon as water travels from the atmosphere, across the landscape/soils, and into inland water systems (Figures 1.1-1.8).

While the basic pathways of water movement across the landscape are well understood, it should be recognized how these pathways are evolving and with what consequences. The global distribution of freshwater resources are shaped by present and future demands along with natural and anthropogenic climate change (Kundzewicz et al., 2008; Döll, 2009), and, as a result, access to potable water is forecasted to decrease globally (Alcamo et al., 2007). Groundwater reserves have received less attention 


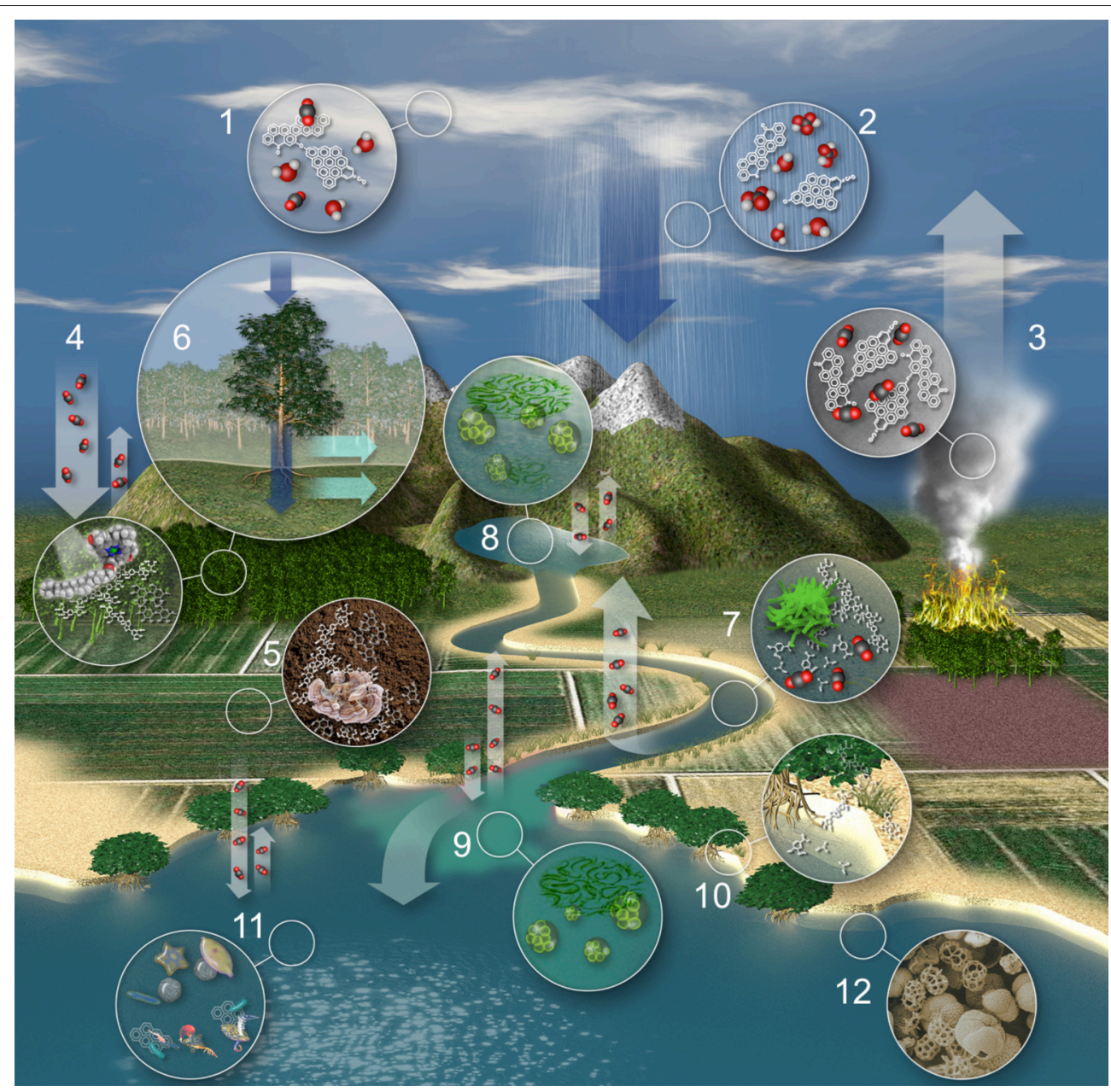

FIGURE 1 | (1) Atmospheric particles act as cloud-condensing nuclei, promoting cloud formation (Kerminen et al., 2000; Riipinen et al., 2011). (2) Raindrops absorb organic and inorganic carbon through particle scavenging and adsorption of organic vapors while falling toward earth (Waterloo et al., 2006; Neu et al., 2016). (3) Burning and volcanic eruptions produce highly condensed polycyclic aromatic molecules (i.e., black carbon) that is returned to the atmosphere along with greenhouse gases such as $\mathrm{CO}_{2}$ (Baldock et al., 2004; Myers-Pigg et al., 2016). (4) Terrestrial plants fix atmospheric $\mathrm{CO}_{2}$ through photosynthesis, returning a fraction back to the atmosphere through respiration (Field et al., 1998). Lignin and celluloses represent as much as $80 \%$ of the OC in forests and $60 \%$ in pastures (Martens et al., 2004; Bose et al., 2009). (5) Litterfall and root OC mix with sedimentary material to form organic soils where plant-derived and petrogenic OC is both stored and transformed by microbial and fungal activity (Schlesinger and Andrews, 2000; Schmidt et al., 2011; Lehmann and Kleber, 2015).(6) Water absorbs plant and settled aerosol-derived DOC and DIC as it passes over forest canopies (i.e., throughfall) and along plant trunks/stems (i.e., stemflow) (Qualls and Haines, 1992). Biogeochemical transformations take place as water soaks into soil solution and groundwater reservoirs (Grøn et al., 1992; Pabich et al., 2001) and overland flow occurs when soils are completely saturated (Linsley et al., 1975) or rainfall occurs more rapidly than saturation into soils (Horton, 1933). (7) Organic carbon derived from the terrestrial biosphere and in situ primary production is decomposed by microbial communities in rivers and streams along with physical decomposition (i.e., photo-oxidation), resulting in a flux of $\mathrm{CO}_{2}$ from rivers to the atmosphere that are the same order of magnitude as the amount of carbon sequestered annually by the terrestrial biosphere (Richey et al., 2002; Cole et al., 2007; Raymond et al., 2013). Terrestrially-derived macromolecules such as lignin (Ward et al., 2013) and black carbon (Myers-Pigg et al., 2015) are decomposed into smaller components and monomers, ultimately being converted to $\mathrm{CO}_{2}$, metabolic intermediates, or biomass. (8) Lakes, reservoirs, and floodplains typically store large amounts of $\mathrm{OC}$ and sediments, but also experience net heterotrophy in the water column, resulting in a net flux of $\mathrm{CO}_{2}$ to the atmosphere that is roughly one order of magnitude less than rivers (Tranvik et al., 2009; Raymond et al., 2013). Methane production is also typically high in the anoxic sediments of floodplains, lakes, and reservoirs (Bastviken et al., 2004). (9) Primary production is typically enhanced in river plumes due to the export of fluvial nutrients (Cooley et al., 2007; Subramaniam et al., 2008). Nevertheless, estuarine waters are a source of $\mathrm{CO}_{2}$ to the atmosphere, globally (Cai, 2011). (10) Coastal marshes both store and export "blue carbon" (Odum et al., 1979; Dittmar et al., 2001; Moore et al., 2011). Marshes and wetlands are suggested to have an equivalent flux of $\mathrm{CO}_{2}$ to the atmosphere as rivers, globally (Wehrli, 2013). (11) Continental shelves and the open ocean typically absorb $\mathrm{CO}_{2}$ from the atmosphere (Cai, 2011), sequestering a small fraction of the fixed $\mathrm{CO}_{2}$ as organic carbon in (12) marine sediments due to the "biological pump" (Moran et al., 2016).

relative to surface waters until recently (Foster and Chilton, 2003; Famiglietti, 2014), but are the primary freshwater source for over two billion people, globally (Alley, 2006; Kundzewicz and Döll, 2009). In addition to intensification of flood/drought cycles, the quality and quantity of surface water is predicted to be negatively influenced by changes to the earth's climate through alteration of rainfall, river flow, and temperatures and associated properties such as organic pollutant and sediment levels (Whitehead et al., 
2009). Alterations to land use are another major factor potentially affecting surface water quality (Seeboonruang, 2012).

At regional scales, river basins are natural integrators of surficial processes. Large rivers owe their flow and chemical loads to a much denser network of small rivers and streams bordered by areas of periodically inundated land. Upland areas are dissected by corridors of wet soils and flowing water. Hence, understanding the hydrological and chemical patterns observed at the mouths of major rivers requires delineating the sequences of biogeochemical processes operating across multiple time and space scales. As embodied originally by the River Continuum Concept, river properties should vary systematically downstream as processes affecting primarily the interactions of flowing water with the landscape give way to within river transport and processing (Vannote et al., 1980; Minshall et al., 1985).

The central premise of a river basin model is that the constituents of river water provide a continuous, integrated record of upstream processes whose balances vary systematically depending upon changing interactions of flowing water with the landscape and the interplay of biological and physical processes (Karlsson et al., 1988). That is, the chemical signatures of riverine materials can be used to identify different drainage basin source regions, reaches or stages, and can be tied to landscape-related processes such as chemical weathering and nutrient retention by local vegetation (Benke and Meyer, 1988). A significant challenge for global biogeochemistry is to determine how the interaction of hydrological and biogeochemical cycles functions at the land surface, on regional to continental scales, producing the river flow and chemical load delivered to the oceans (Meybeck, 1982).

\section{Above-Ground Carbon Flow Paths}

The interaction of water with OM begins before rain falls to the earth's surface. Aerosols and organic vapors act as cloud condensing nuclei, stimulating cloud production (Figure 1.1; Kerminen et al., 2000; Riipinen et al., 2011). Aerosol particles come from various sources such as aeolian transport of dust, terrestrial plants (e.g., isoprene emission), combustion of plant biomass and fossil fuels (i.e., "black carbon"), and agricultural/ industrial activities (Simoneit and Elias, 2000; Pio et al., 2001; Snyder et al., 2009).

Once a raindrop precipitates, the water gains dissolved organic matter (DOM) from these same atmospheric particles and vapors, resulting in DOM concentrations order(s) of magnitude greater than those observed in inland waters and the ocean (Figure 1.2; Artaxo et al., 1988; Waterloo et al., 2006; Germer et al., 2007; Neu et al., 2016). Soils are an important source of OM that is present in atmospheric water vapor. For example, while hailstones from storm clouds harbor primarily plant-surface bacteria, the molecular composition of DOM contains mainly soil-derived sources suggesting a fast transfer of OM from soils to the atmosphere (Šantl-Temkiv et al., 2013). In addition to being solubilized to DOM (Greenfield, 1957), particulate organic matter (POM) is also "washed" from the atmosphere by rainfall, acting as an additional flux of carbon to the earth's surface (Monteith et al., 2007).

Rainfall becomes increasingly enriched in DOM and POM as it passes through forest canopies (i.e., throughfall; Figure 1.6;
Germer et al., 2007) and vegetation layers (i.e., stemflow; Levia and Frost, 2003), while biological transformations also begin to rapidly convert organic substrates into inorganic carbon. For example, in an Appalachian forest $14-33 \%$ of the dissolved organic carbon (DOC) mobilized by above ground flow paths was degraded during incubation experiments. DOC was consumed most rapidly in throughfall samples with rates decreasing vertically along organic and inorganic soil horizons (Qualls and Haines, 1992).

In the tropical Amazon basin, the flux of DOC in rainfall ranges from $27.5 \mathrm{~kg} \mathrm{ha}^{-1}$ year $^{-1}$ in the Rio Negro, a relatively pristine forested area in the central Amazon (Filoso et al., 1999), to a maximum of $123.4 \mathrm{~kg} \mathrm{ha}^{-1}$ year $^{-1}$ in Paragominas, a heavily deforested area in the eastern Amazon (Markewitz et al., 2004), with the highest rainfall fluxes occurring near transitional regions with significant deforestation and burning (Neu et al., 2016). Considering hydrologic regimes are similar in the above regions, the concentration of DOC in rainfall is the largest factor driving these differences in rainfall DOC fluxes. Throughfall fluxes are generally the highest of each respective flow path in the tropics, with net fluxes (i.e., not including rainfall DOC) ranging from $68.4 \mathrm{~kg} \mathrm{ha}^{-1}$ year $^{-1}$ (Neu et al., 2016) to $195.1 \mathrm{~kg} \mathrm{ha}^{-1}$ year $^{-1}$ (Germer et al., 2007) in the Amazon, compared to a stem flow flux of $1.5 \mathrm{~kg} \mathrm{ha}^{-1} \mathrm{year}^{-1}$ (Neu et al., 2016). The abundance and composition of DOM in these above-ground flowpaths is largely controlled by the type of vegetation/landscape that the water is exposed to and surface properties of plants such as leaf composition, surface texture (i.e., rugosity), and the abundance of epiphytes (Neu et al., 2016).

Overland flow occurs when rainfall occurs more rapidly than soil infiltration (Horton, 1933) or when soils are completely saturated (Figure 1.6; Linsley et al., 1975). Impermeable surfaces, which are prevalent in urban settings, greatly enhance overland flow and allows for the mobilization of urban pollutants such as brake dust and oil into storm drains and receiving waters (Gromaire-Mertz et al., 1999; Davis et al., 2001; Shuster et al., 2005). Overland flow is generally limited to extreme rain events, and represents a relatively minor carbon flux relative to rainfall and throughfall. In the Arctic, certain regions have experienced a decrease in the role of DOM from overland flow to rivers, with greater importance on lateral flow inputs of deep soil sources due to greater thaw and increased infiltration of snowmelt waters through the active soil layer (Striegl et al., 2005; Aiken et al., 2014).

There are only a limited amount of studies comparing OM fluxes and transformations through above ground flow paths, prior to entering soils and streams, which is a critical gap in data coverage along the aquatic continuum. For example, the use of biomarkers to unravel OM sources in aquatic systems depends on knowing the past history of these molecules with certainty. However, processes such as selective leaching of plantderived compounds from litterfall and soils (Hernes et al., 2007) or sorption/desorption of organic molecules in transit (Aufdenkampe et al., 2001) complicate interpretations of these signatures. For example, differences in the ratio of specific lignin phenols (i.e., common terrestrial plant biomarkers) are often attributed to differences in vegetation sources and degradation 
state, but these signatures can be greatly altered by selective fractionation while moving through the aforementioned flow paths (Hernes et al., 2017). Development of robust biomarker proxies for organic matter provenance, prior processing, and paleoclimate requires a quantitative understanding of how organic molecules evolve along the entire terrestrial-aquatic continuum.

\section{Below-Ground Carbon Flow Paths}

After percolating through vegetation layers and the landscape, rainfall absorbs into soils (Figure 2). Soils contain a complex mixture of $\mathrm{OM}$ derived from the overlaying vegetation, root systems, in situ microbial and fungal activity, and carbon mobilized by above-ground flowpaths (Figure 1.5). The evolution of the quantity and composition of OM with soil depth is largely controlled by microbial processing and transitions between solid and aqueous phases via sorption/desorption (Kalbitz et al., 2000; Vieublé Gonod et al., 2006; Schmidt et al., 2011). Soil mineral structure exerts an important control on soil OM storage over geological time scales (Torn et al., 1997). However, the concept of soils being primarily composed of inherently stable humic substances is being revised to recognize the diversity of $\mathrm{OM}$ and dynamic processes acting on these molecules (Medeiros et al., 2006; Lehmann and Kleber, 2015). Despite large differences in OM delivery mechanisms, soils share many similarities with aquatic/marine sediments, typically ranging between 0.5 and $5 \%$ organic carbon (OC) by weight, with higher values observed in OM-rich settings like permafrost and peatlands (Keil and Mayer, 2014).

OM present in soils is tightly linked to mineral surfaces, with sorption/desorption altering the composition of OM ultimately mobilized from soils into streams. Mineral associations both in soils/sediments and aquatic ecosystems can protect OM from substantial microbial decomposition. There are generally four types of interactions between $\mathrm{OM}$ and minerals: (1) Ligand exchange, or sorption of small molecules to mineral surfaces; (2) Sorption of large molecules such as proteins to several mineral surface contact points; (3) aggregation (i.e., chemical bonding or van der Waals attractions); and (4) occlusion (i.e., covering of $\mathrm{OM}$ in a mineral structure such as diatom frustules), which offers the most substantial protection of OM (Keil and Mayer, 2014).

Sensitivity of organic molecules to oxygen, or rather the dependence of microbial activity on oxygen content, and the amount of exposure time to oxygen is another factor determining selective preservation of $\mathrm{OM}$ in sediments, soils, and aquatic environments (Arnarson and Keil, 2007; Burdige, 2007). The most recent paradigm on OM degradability in soils emphasizes the importance of the factors described above along with microbial adaptations and community structure (Schmidt et al., 2011). These same principles apply to $O M$ in the aqueous phase, where the majority of $\mathrm{OM}$ is decomposed soon after its synthesis. For example, more than $99 \%$ of DOM is decomposed within a decade of being produced, with only a small fraction of molecules overturning on centennial to millennial time scales and accumulating in the ocean (Dittmar, 2015).

Water that enters the soil matrix moves along gradients in the landscape's topography and saturation state, ultimately being expressed as groundwater or stream flow interconnected by the hyporheic zone (Figure 2; Brunke and Gonser, 1997). Although, roughly $97 \%$ of the earth's freshwater supply resides underground, the ecological dynamics of groundwater are relatively understudied in comparison to rivers and lakes (Gibert et al., 1994). Deep groundwater settings have traditionally been considered "closed systems" with respect to ecological dynamics due to long water and solute residence times (i.e., centuries to millennia; Fetter, 1988), whereas shallow groundwater systems have a close connection to surface waters on more rapid timescales (Toth, 1963) through the surface water-groundwater interface (Jones and Holmes, 1996; Brunke and Gonser, 1997; Boulton et al., 1998).

The concentration of DOM in groundwater is largely influenced by its source (e.g., soils, the riparian zone, and above ground flow paths) and the extent of heterotrophic decomposition since these constantly dark settings generally experience no in situ primary production (Ghiorse and Wilson, 1988; Chapelle et al., 2009; Shen et al., 2015). OM in the riparian zone can be derived from both autochthonous sources (e.g., vegetation and soils) and from the river itself (Clinton et al., 2002; Blazejewski et al., 2009; Peter et al., 2012a). The distance that water and carbon moves through soils unsaturated with moisture (e.g., the vadose zone) is an important control on groundwater DOM concentrations, with the lowest DOM concentrations being observed in regions with deep vadose zones. DOM concentrations are generally lower in below ground stocks relative to above ground counterparts largely due to the effects of microbial processing (Peter et al., 2012b; Neu et al., 2016). For example, Baker et al. (2000) demonstrated that snow-melt was an important source of both DOM and dissolved oxygen to groundwater in a mountainous setting in New Mexico, USA. As a result of these snow-melt driven fluxes, roughly $45 \%$ of the leached DOC was estimated to be consumed based on microcosm experiments (Baker et al., 2000). In an unconfined aquifer in Denmark roughly $11 \%$ of bulk groundwater DOC could be microbially-decomposed, whereas 27 and $28 \%$ of fractionated low molecular weight and hydrophilic organic molecules were degraded, respectively (Grøn et al., 1992). Biotic and abiotic transformations occurring in both above and below ground flow paths ultimately determine the quantity and composition of OM delivered to river networks and eventually the coastal ocean and/or atmosphere.

\section{Mobilization of OM from Soils to Streams}

Processes occurring in soils along with solubility characteristics directly affect the quantity and composition of organic and inorganic constituents that are stored in soils and mobilized into groundwater and rivers/streams (Figure 3; Sanderman et al., 2009). Hydrologic flowpaths through the uppermost OM-rich soil layer exert an important control on soil OM concentrations. For example, modern-aged OM (i.e., less than $\sim 100$ years old) is flushed from upper soil layers, depleting soil $\mathrm{OM}$ concentrations and leaving behind older OM in deeper soil horizons during storm events (Schiff et al., 1998; van Verseveld et al., 2009). Easthouse et al. (1992) estimated that base river flow consists of OM primarily from deep soil layers, 


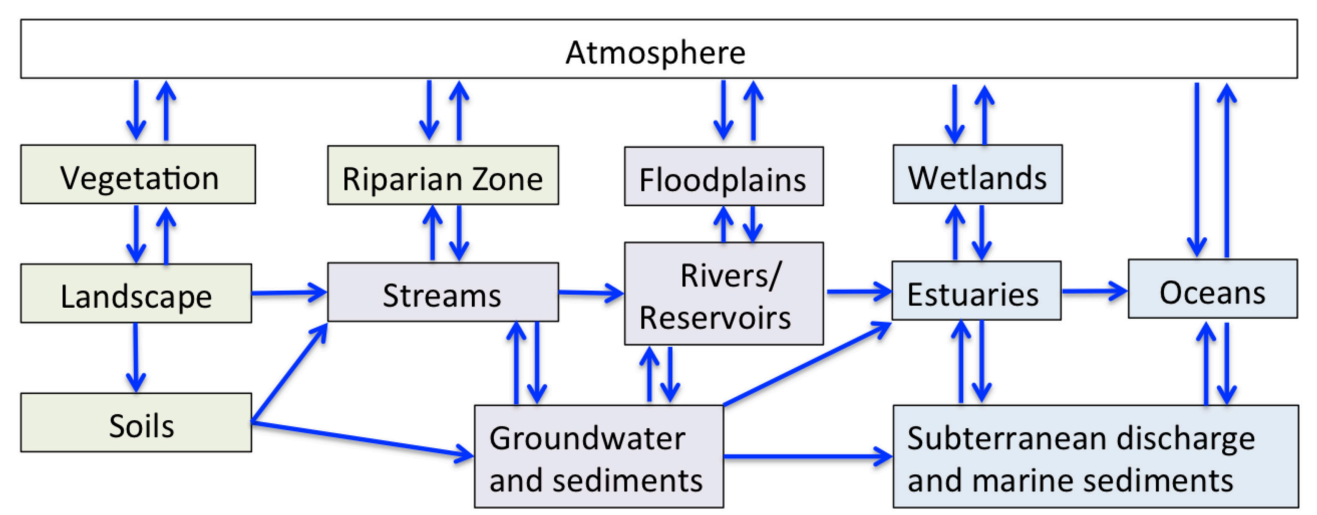

FIGURE 2 | The flow of water and associated geochemical constituents (blue arrows) through atmospheric (white), terrestrial (green), freshwater (purple), and estuarine/marine (blue) reservoirs.

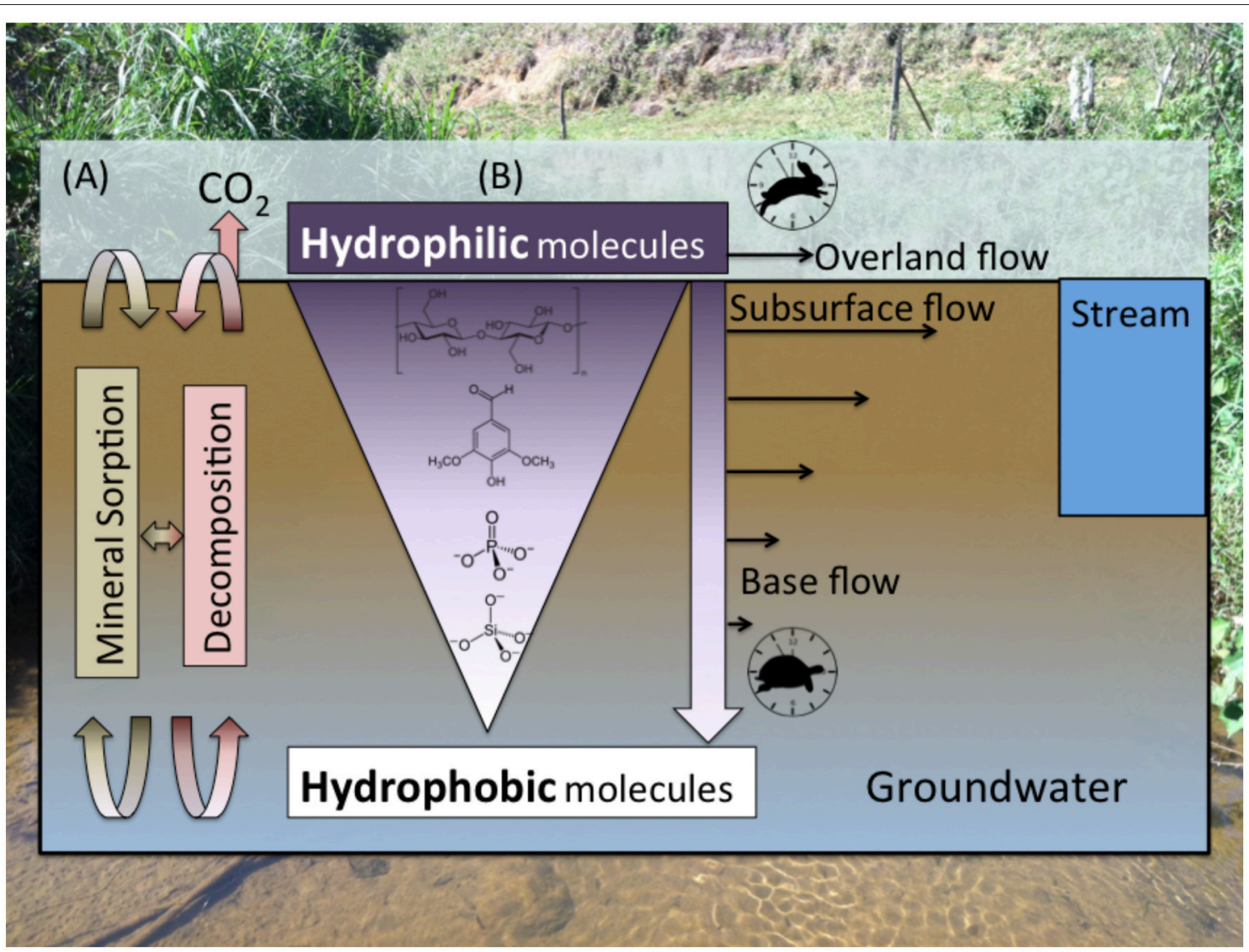

FIGURE 3 | (A) The composition of organic matter and inorganic constituents along soil profiles is controlled by the interplay between stabilization/dissolution via mineral sorption/desorption; microbial decomposition, which is dependent on microbial community composition/activity and redox/environmental conditions (e.g., Schmidt et al., 2011); and (B) preferential mobilization of more soluble molecules (Kaiser et al., 2004), which is dependent on polarity and molecular size/charge, by rapid overland flow and shallow subsurface flow relative to slow base flow. Inorganic constituents such as silicate and phosphate, which are important nutrients for aquatic production, are mobilized more slowly than $\mathrm{OM}$, meaning most of their flux is attributed to base flow.

whereas $50-65$ and $35-50 \%$ of the OM mobilized by peak flow originates from the subsoil and organic soil horizons, respectively.
Dissolved organic carbon (DOC) and organic/inorganic nitrogen concentrations generally increase during periods of heavy rainfall, but most storm sampling campaigns to date have 
focused only on temperate settings (Boyer et al., 1997; Hinton et al., 1998; Hill et al., 1999; Buffam et al., 2001; Raymond and Saiers, 2010; Ward et al., 2012). Relatively insoluble constituents such as silicate and phosphate, on the other hand, are generally only mobilized by slow base flow and diluted by heavy rainfall events (Kennedy, 1971; Ward et al., 2012). The relatively slow mobilization of inorganic constituents such as phosphate and silicate relative to $\mathrm{C}$ and $\mathrm{N}$-containing molecules (Figure 3) exerts an important control on nutrient limitation for in situ primary production both within inland waters and marine receiving waters.

Raymond et al. (2016) recently described these mobilization dynamics within the context of the "Pulse Shunt Concept (PSC)," whereby OM is pulsed into streams during extreme hydrologic events (e.g., heavy rainfall or large snow/ice melting events) and subsequently shunted from headwater streams into larger rivers prior to significant microbial or photo-oxidative transformation. This shunting of OM can alter downstream reactivity gradients and also allow for the export of reactive $\mathrm{OM}$ that maintains terrestrial signatures (Raymond et al., 2016). PSC evolved from conceptual frameworks such as the river continuum concept (RCC), which describes a decreasing complexity of OM composition from headwater streams to large downstream river networks due to microbial communities adapted to take advantage of the inefficiencies of upstream communities (Vannote et al., 1980). Additional models evolved and built upon RCC such as the spiraling concept describing reach-scale DOM removal in sediment biofilms (Newbold et al., 1982); the inclusion of unique environments such as floodplains into the linear drainage network (Junk et al., 1989; Sedell et al., 1989; Ward and Stanford, 1995); and the riverine ecosystem synthesis model, which provides a framework for integrating discontinuous hydrogeomorphic patches (Thorp et al., 2006; McCluney et al., 2014). Creed et al. (2015) suggested that rivers trend toward a state of chemostasis, with the control on DOM levels shifting from primarily hydrologic in headwaters and small streams (resulting in a correlation between discharge and concentration) to in/near-stream biogeochemical processing further downstream along the continuum (Figure 4), resulting in a preferential loss of aromatic molecules relative to aliphatic (Figure 1.7).

The residence time of water is one aspect of OM transport that is particularly emphasized in the PSC framework. The time a water molecule and associated OM spends in each river compartment ultimately determines its fate and extent of downstream advection (i.e., shunting). Although PSC addresses rapid loading events, a similar concept can be applied to understanding broader differences between watersheds with different topological regimes. For example, in a steep drainage basin such as the Ganges-Brahmaputra, which drains a large area of South Asia, water moves rapidly toward the sea along a steep gradient and, as such, a large amount of terrestriallyderived OM can be found preserved in coastal sediments (Galy and Eglinton, 2011). In contrast, systems with a more gradual drainage footprint and longer water residence times, such as the Amazon River, deliver less bio-reactive OM to the ocean, with the majority (i.e., $\sim 95 \%$ ) of transported OM being converted to $\mathrm{CO}_{2}$ in the basin's rivers and soils/sediments (Richey et al., 2002; Ward et al., 2013, 2015).

\section{TRANSFORMATION AND STORAGE OF OM IN INLAND WATERS}

The decomposition of terrestrially-derived OM continuously occurs as rivers and streams travel downhill toward the sea, driving the production of greenhouse gases such as methane $\left(\mathrm{CH}_{4}\right)$ and $\mathrm{CO}_{2}$ (Figure 1.7; Duarte and Prairie, 2005; Battin et al., 2008), and also fuels lotic food webs (Tank et al., 2010). As a result, streams, rivers and estuaries are usually oversaturated in dissolved $\mathrm{CO}_{2}$ and $\mathrm{CH}_{4}$ in comparison with atmospheric levels, leading to degassing of these GHGs to the atmosphere from surface waters (Raymond et al., 1997; Richey et al., 2002; Borges and Abril, 2011) and vegetation (Bergström et al., 2007). This phenomenon has been observed throughout the world and is expressed most strongly in the tropics, where warm temperatures stimulate OM decomposition (Raymond et al., 2013). This section describes the processing and storage of OM along inland water systems.

\section{Conversion of $\mathrm{OM}$ to $\mathrm{CO}_{2}$ in Inland Waters}

The main source of $\mathrm{CO}_{2}$ to small streams is subsurface flow from riparian soils (Jones and Mulholland, 1998; Johnson et al., 2008). Up to $90 \%$ of the dissolved $\mathrm{CO}_{2}$ in first order streams comes from microbial and root respiration in the soil and is delivered to the stream via lateral flow of groundwater. As stream size increases, the contribution of $\mathrm{CO}_{2}$ inputs from soil respiration decreases, while the in situ oxidation of allochthonous organic matter plays a larger role in controlling $\mathrm{CO}_{2}$ levels (Butman and Raymond, 2011). In running waters, the controls on GHG production and evasion is in part a function of hydrologic and geomorphologic features that result in fluvial environments with different balances between production, consumption, import, and export of these gases (Borges et al., 2015; Stanley et al., 2016).

Lakes, reservoirs, and floodplains act as important regulators on both the breakdown and storage of OM (Figure 1.8; Cole et al., 1994; Tranvik et al., 2009; Kellerman et al., 2015). Floodplains and lakes often represent areas of enhanced primary production, providing the river with fresh autochtonous OM (Junk et al., 1989; Melack and Forsberg, 2001; Benedetti et al., 2003). High levels of algal and aquatic plant production (Junk and Howard-Williams, 1984; Junk et al., 1989) can considerably enhance the overall export of DOM from a river system (Tockner et al., 1999; Hedges et al., 2000). In fact, the extent of wetland coverage is often linked to DOC concentrations (Spitzy and Leenheer, 1991; Mann et al., 2014) and can be used to predict DOC distributions in stream/river networks (Gergel et al., 1999). It has been suggested that floodplains are the primary driver for $\mathrm{CO}_{2}$ outgassing from tropical rivers (Abril et al., 2014). However, this conclusion is at odds with the rapid conversion of terrestrially-derived $\mathrm{OM}$ to $\mathrm{CO}_{2}$ in both rivers and floodplains (e.g., Ward et al., 2013, 2016). Floodplains essentially transport $\mathrm{CO}_{2}$ from the atmosphere to the water via aquatic plant primary production and subsequent plant respiration. This $\mathrm{CO}_{2}$ 


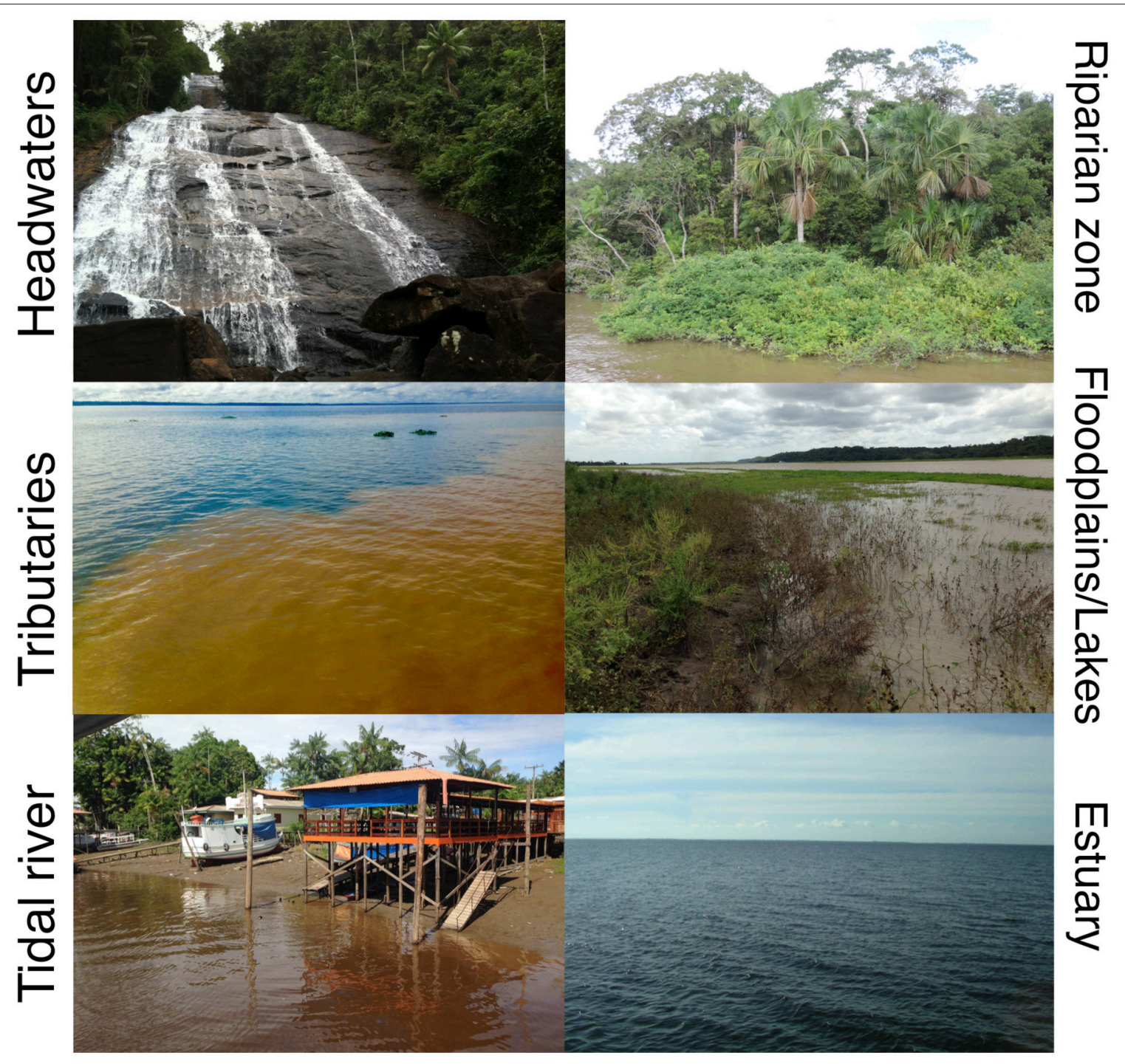

FIGURE 4 | Geochemical components are constantly mobilized into the aquatic setting from soils and vegetation in the surrounding watershed, the riparian zone, and floodplains as water flows from headlands to the sea. Reactive components are transformed along the continuum as water flows through the river network, with OC storage and autochthonous production mostly occurring in floodplains, lakes, and reservoirs (not shown). The amount of potentially reactive $\mathrm{OC}$ that reaches the estuary, where fresh and saline waters meet, is a function of watershed/river physiochemical characteristics and water residence time.

is advected downstream and returned to the atmosphere via degassing, ultimately resulting in a net zero exchange unless there is appreciable production of recalcitrant OM by these aquatic plants (not currently constrained). The breakdown of terrestrially-derived OM in rivers, on the other hand, represents a large exchange between terrestrial and aquatic biospheres and the dynamic conditions along this gradient allows OM that may have otherwise been preserved in soils/sediments to be returned to the atmosphere as $\mathrm{CO}_{2}$.

Organic matter stored in rocks, or petrogenic OM, is the largest global pool of organic carbon and is mobilized into modern biogeochemical cycles through chemical weathering and rock uplift (Hedges, 1992). The age of $\mathrm{OM}$ and $\mathrm{CO}_{2}$ in rivers varies drastically across space and time due to the complex mobilization dynamics previously discussed and heterogeneity in physiochemical characteristics across not only latitudes, but within a basin (Raymond et al., 2004). For example, the radiocarbon age of POM in the Mekong River varies from 3000 years old during the low water period to modern during the high water period (Martin et al., 2013). DOM and particulate lignin phenols, on the other hand, were ubiquitously young throughout the hydrograph, indicating a rapid cycling of the majority of the DOM pool and, likewise, fresh vascular plant derived OM in the particulate phase (Martin et al., 2013). Similar observations have been made in the Amazon basin, where DOM ages were also ubiquitously young, whereas POM ranged from old in the headwaters to modern in the lowland rivers likely due to a dilution of old petrogenic carbon with fresh litter and rapid 
cycling of DOM (Mayorga et al., 2005). Dissolved $\mathrm{CO}_{2}$ in the Amazon basin shifts from old (e.g., centennial to millennial ages) in the mountainous headwaters where carbonate weathering is a significant input to the water column to modern in carbonatefree and lowland rivers, where microbial decomposition of young $\mathrm{OM}$ in soils, streams, and the water column is the primary source of $\mathrm{CO}_{2}$ to the river network (Mayorga et al., 2005).

Although ancient OM was traditionally assumed to be recalcitrant due to its ability to persist in the environment for millenia, microbes are capable of breaking down and assimilating/respiring old petrogenic $\mathrm{OM}$ once mobilized into the aquatic setting (Petsch et al., 2001; Berner, 2004; McCallister et al., 2004; Galy et al., 2015), which, along with burial in the ocean and volcanic eruptions, is an important process controlling atmospheric $\mathrm{CO}_{2}$ levels over geological time scales (Mackenzie and Lerman, 2006). Most of this biologically transformed ancient $\mathrm{OM}$ is converted to $\mathrm{CO}_{2}$ rather than assimilated and moved up trophic levels (Dittmar and Kattner, 2003). The breakdown of old OM is particularly relevant in the Arctic, where warming is expected to thaw permafrost and push the boundary for regions where permafrost can exist to higher latitudes, releasing large amounts of ancient OM into rivers (Guo et al., 2004; Hood et al., 2009; Hessen et al., 2010; Spencer et al., 2015).

The reactivity of permafrost-derived carbon varies seasonally, with the most reactive substrates being flushed during the spring freshet (Holmes et al., 2008). The age of OM has also been observed to become progressively younger along downstream gradients in the Arctic (Mann et al., 2015), which the authors attribute to biological degradation. Glacial runoff is another important source of ancient reactive OM to the ocean (Stubbins et al., 2012a). Considering that glaciers and ice sheets are the second largest pool of water in the global hydrologic cycle, the melting of glaciers and ice sheets has the potential to not only raise sea level, but also act as a positive feedback for the accumulation of $\mathrm{CO}_{2}$ in the atmosphere (Hood et al., 2009). Beyond environmental responses to climate change, the mobilization of old carbon from natural ecosystems throughout the world is being affected by human alterations to the landscape. Observations of a linkage between the age of DOM in rivers and population density, land cover, and other environmental variables suggests that human disturbance is increasing the rate at which aged $\mathrm{OM}$ is mobilized from the terrestrial landscape into rivers (Butman et al., 2015).

\section{Methane Cycling in Inland Waters}

Large amounts of methane are generally produced in the anoxic, OM-rich sediments of lakes and floodplains. For example, lakes emit roughly 8-48 $\mathrm{Tg} \mathrm{CH}_{4}$ year $^{-1}$, which is $6-16 \%$ of natural methane emissions and exceeds methane emissions from the ocean (Bastviken et al., 2004, 2011; Kirschke et al., 2013). In freshwater environments it has been estimated that anaerobic carbon mineralization contributes to $20-60 \%$ of total carbon mineralization rates (Boon and Mitchell, 1995; Hamilton et al., 1995; Utsumi et al., 1998), with methanogenesis making up 30$80 \%$ of this anaerobic activity (Kuivila et al., 1988; Bédard and Knowles, 1991). As such, it has been estimated that $20-59 \%$ of the OM delivered to sediments via suspended particles is converted to methane (Wetzel, 2001 and references therein). However, a large fraction (30-99\%) of methane produced in aquatic systems can be converted to $\mathrm{CO}_{2}$ via microbial $\mathrm{CH}_{4}$ oxidation in the water column prior to being evaded to the atmosphere (Liikanen et al., 2002; Kankaala et al., 2006; Bastviken et al., 2008). For example, in the Amazon River it has been estimated that $\mathrm{CH}_{4}$ emissions are reduced by as much as $96 \%$ due to oxidation (Sawakuchi et al., 2016).

Human intervention in river hydraulics by impoundments is known to change the dynamics of $\mathrm{CO}_{2}$ and $\mathrm{CH}_{4}$ production and emissions (Crawford and Stanley, 2016; Crawford et al., 2016). By impeding water flow, reservoirs function as a trap for the suspended sediment load in rivers. The burial of OM associated with these sediments can represent an important carbon sink in these man-made environments (Dean and Gorham, 1998; Mendonça et al., 2014). On the other hand, these depositional environments are also hotspots for methane production and subsequent emissions to the atmosphere (Delsontro et al., 2010; Jacinthe et al., 2012; Maeck et al., 2013). Another effect of sediment deposition is increased light penetration and in situ primary production. The growth of the phytoplankton community is an important source of labile organic matter that fuels $\mathrm{CH}_{4}$ production in reservoir sediments (Mendonça et al., 2012). This $\mathrm{CH}_{4}$ produced in the reservoir is not only released from the reservoir surface but also from downstream waters (Guerin et al., 2006).

Reservoir $\mathrm{CH}_{4}$ emissions can be further amplified by the conversion of dry land, which in many cases acts as a sink of atmospheric $\mathrm{CH}_{4}$ due to methanotrophic bacterial consumption in the aerated soil (Curry, 2007), into flooded anaerobic areas where $\mathrm{CH}_{4}$ production is typically high due to the decay of flooded OM present in the soil when reservoirs are constructed (Kemenes et al., 2007). Thus, reservoirs emit particularly large amounts of $\mathrm{CO}_{2}$ and $\mathrm{CH}_{4}$ produced by the decomposition of this flooded terrestrial OM during the first decade or so of dam operations (Abril et al., 2005). Reservoirs contribute to roughly $18 \%$ of global anthropogenic methane emissions, while natural emissions from lakes are estimated to be $6-16 \%$ of total nonanthropogenic $\mathrm{CH}_{4}$ emissions (St Louis et al., 2000; Bastviken et al., 2004). The rapid conversion of methane into $\mathrm{CO}_{2}$ in naturally flowing waters presents an important issue with respect to hydropower dam operations. The release of methane gas to the atmosphere can be significantly intensified as water travels through dam turbines and in the quickly flowing, turbulent waters downstream of a dam, which essentially allows methane to bypass oxidation further downstream in the river continuum (Fearnside, 1995, 2004).

\section{OM Storage in Inland Waters}

Although OM is rapidly cycled in inland waters, lake sediments represent regions of significant $\mathrm{OM}$ burial due to high sedimentation rates and burial efficiencies (Figure 1.8; Tranvik et al., 2009). Total OM burial rates in lakes and reservoirs are thought to be 1 to 4 times greater than the ocean (Einsele et al., 2001; Tranvik et al., 2009). It has been suggested that total continental OM burial is an order of magnitude higher than 
marine burial and that most of this OM is derived from humaninduced erosion (Wilkinson and McElroy, 2007). However, it is also thought that marine OC burial rates may be underestimated compared to lakes (Aufdenkampe et al., 2011).

OM burial rates have continued to increase in lakes and reservoirs since the industrial revolution (Mulholland and Elwood, 1982; Webb and Webb, 1988) as a result of increased land use change (Anderson et al., 2013), conversion of natural land into agricultural plots, and eutrophication in inland water bodies (Dean and Gorham, 1998; Anderson et al., 2014). In addition to enhanced burial rates, the spatial expanse of impounded waters is continuing to increase. For example, the amount of impounded area in the conterminous U.S. has increased by roughly 1\% per year since 1960 (Clow et al., 2015), with similar rates of expansion in developing countries (Downing et al., 2006). However, there is not currently a consensus on whether sedimentary OM trapped behind dams is truly "stored" considering it is susceptible to human manipulation of the hydrologic regime and remobilization.

When evaluating the fate of OM stored in reservoirs vs. manmade lakes with respect to global carbon budgets, it is important to consider that OM stored in reservoir sediments typically has a shorter residence time than in lakes due to hydrologic manipulation and associated resuspension and export processes (Clow et al., 2015). This means that OM that was once stored in a reservoir can be readily mobilized back into the aquatic environment, where environmental conditions such as elevated oxygen levels and adapted microorganisms are more suitable for biological decomposition.

\section{ESTUARIES AND COASTAL OCEANS}

Estuaries represent a direct link between fresh and saline waters. Large rivers also contain freshwater estuaries, in a sense, where tides completely reverse the flow of water semi-diurnally, but the force of the river's discharge is strong enough to maintain a salinity of zero (Figure 4). The dynamic environmental conditions along these evolving ecotones provide an abundance of unique ecosystem niches driving high levels of biodiversity and productivity. As a result, estuaries provide a large suite of ecosystem services such as nutrient/pollutant cycling, sediment and carbon storage, buffers for storm and flooding events, and fisheries production (Canuel et al., 2012). Considering that over $75 \%$ of the world's population surrounds coastal regions (Vitousek et al., 1997; Lubchenco and Petes, 2010), estuaries and coastal oceans not only connect natural terrestrial/marine biogeochemical cycles, but also represent a central connection between human societies, international commerce, and the environment. For example, the ecosystem services described above provide an economic value greater than $\$ 25$ trillion, annually (Nellemann et al., 2009; Barbier et al., 2011).

This close connection has resulted in negative alterations and perturbation of natural estuarine/coastal biogeochemical cycles on a global scale. Activities such as dam construction, river diversions/leveeing, conversion of natural landscapes to agricultural land uses, and urbanization have altered the export of sediments, nutrients, and pollutants to coastal waters, which can result in negative consequences such as hypoxia that can have a large impact on valuable ecosystem services (Lotze et al., 2006; Diaz and Rosenberg, 2008; Rabalais et al., 2009; Lotze, 2010). For example, alterations to floodplain networks can reduce aquatic DOC levels, which limits the presence of environments that promote a reduction in nutrient concentrations via denitrification (Philip and Townsend, 2010). Anthropogenic hypoxia is often attributed to agricultural inputs of fertilizers (Rabotyagov et al., 2014), but wetland loss in managed watersheds such as the Mississippi River is likely another important factor to consider (Mitsch et al., 2005; Schramm et al., 2009; Duan et al., 2017). Likewise, increased export of terrestrially-derived $\mathrm{OM}$ due to watershed perturbations and its subsequent decomposition in coastal waters is not currently considered to be a factor driving hypoxia, but may play an important role.

\section{Sediment and OM Transport from Large Rivers}

Coastal shelf seas are often strongly affected by the riverine input of nutrients and OM (Figure 1.9). Shelf seas only represent a small part of the total ocean surface, but account for 15$30 \%$ of primary procuction in the ocean and up to $50 \%$ of export production (Wollast, 1998). Roughly $80 \%$ of the total OM transport to ocean sediments happens in the shallow water depths of shelf seas (Figure 1.12; Borges, 2005). Because of their high economic value, shelf seas, sandy shorelines, and estuaries are not only exposed to increasing anthropogenic pressure but are also threatened by sea-level rise (Dugan et al., 2010; Bauer et al., 2013). Despite their importance, carbon cycling dynamics in shelf seas are still not well understood, mostly due to the high complexity of carbon sources and sinks (Gattuso et al., 1998).

Rivers represent an important source of $\mathrm{OM}$ to the ocean, influencing biogeochemical cycling along ocean margins. Constraining the connectivity between coastal systems and the deep sea has received considerable attention in recent years. Many coastal margins adjacent to large-river delta-front estuaries (LDEs, Bianchi and Allison, 2009) are surmised to export a relatively small volume of river-derived particulate matter seaward of the shelf break either due to: (1) their location on wide, passive continental margins where deltaic sedimentation is confined to the inner shelf or (2) because they are located where shelf-dominated coastal currents occur (McKee et al., 2004). This has led to the prevailing dogma that continental shelf sediments are hemipelagic in nature, i.e., composed of a mixture of fine biogenic particles derived from marine production $(5-75 \%$ by volume) and terrigenous silt (Shanmugam et al., 1985; Stow et al., 1985). However, it is becoming increasingly recognized that some LDEs (e.g., Sepik, Ganges-Brahmaputra, Eel, and Rhone) are characterized by direct export of large volumes of sediment and OM to the lower continental margin due to: (1) a narrow (active continental margin) shelf (Kineke et al., 2000; Mullenbach and Nittrouer, 2006); (2) progradation of the deltaic clinoform in the late Holocene near to the shelf edge (Coleman et al., 1998); (3) density-driven, cold shelf water 
(winter) advection (Puig and Palanques, 1998); or (4) landward incision of the associated submarine canyon so that it intercepts along-shelf transport pathways (Johnson et al., 2001; Michels et al., 2003). The Mississippi River margin possesses two of these characteristics (2 and 4), making it a candidate for large-scale OM export.

Much of the OM from the Mississippi River and shelf may accumulate in the deeper slope and canyon regions (Bianchi et al., 2006). The Mississippi and Atchafalaya Rivers deliver $60 \%$ of the suspended matter $\left(2.1 \times 10^{14} \mathrm{~g}\right)$ and $66 \%$ of the dissolved materials $\left(3.1 \times 10^{12} \mathrm{~g} \mathrm{OC}\right)$ transported from the conterminous U.S. to the ocean. POM introduced by the river or biologically fixed on the Louisiana shelf is carried along-shelf, decomposed, buried, or transported to deeper regions in the Gulf of Mexico. Vertical fluxes of OC in the Mississippi River plume as high as $1.80 \mathrm{~g} \mathrm{C} \mathrm{m}^{-2} \mathrm{~d}^{-1}$ have been observed during spring (Redalje and Fahnenstiel, 1994), but are lower during other seasons (0.29-0.95 $\left.\mathrm{g} \mathrm{C} \mathrm{m}^{-2} \mathrm{~d}^{-1}\right)$ and away from the immediate plume (0.18-0.40 $\left.\mathrm{g} \mathrm{C} \mathrm{m}^{-2} \mathrm{~d}^{-1}\right)$. In fact, the highest OC burial rates in sediments $\left(\sim 300 \mathrm{~g} \mathrm{C} \mathrm{m}^{-2} \mathrm{y}^{-1}\right)$ occur near the mouth of Southwest Pass (Sampere et al., 2011).

The active (Plaquemine-Balize) lobe of the delta has prograded in the last $\sim 1300$ year close to the shelf break. Sediment accumulation rates on the shelf (based on ${ }^{210} \mathrm{~Pb}$ ) are higher in a tongue extending outward from the depocenter on the delta front toward the canyon head, which may allow for the rapid transport of shelf-derived primary production to the canyon floor, derived largely from diatoms (Lohrenz et al., 1999; Wysocki et al., 2006). In fact, past studies have observed that labile OM, likely produced by in situ diatom production in the Mississippi River plume, is rapidly transported to the Mississippi Canyon (Bianchi et al., 2006; Waterson and Canuel, 2008). These observations suggest that productive LDEs and adjacent shelf regions, such as the Mississippi, may be important conduits for transporting fixed carbon from highly productive plume waters on the shelf to deeper benthic communities.

In other settings, such as the Mediterranean Gulf of Lions margin, dense shelf water cascading (DSWC) has been observed to result in extensive export of water, sediment, and associated OM (Canals et al., 2006). DSWC is the result of contrasting seawater densities due to cooling and/or evaporation, and, as such, varies seasonally and is potentially sensitive to global climate change. DWSC has been observed throughout the world's coastal margins in both high and low latitude settings (Whitehead, 1987; Shapiro et al., 2003; Ivanov et al., 2004).

The largest 25 rivers by discharge drain $\sim 28 \%$ of the Earth's landscape, resulting in over $40 \%$ of the global flux of DOC from rivers to the ocean (McKee, 2003). The oceanic fate of this terrigenous DOC has important ramifications for the global carbon cycle, but remains enigmatic. Multiple studies have observed the remineralization of a large fraction of the terrigenous material exported to ocean margins (Letscher et al., 2011; Fichot and Benner, 2014). This is because terrigenous DOM can experience substantial alterations over relatively short time scales (Hernes and Benner, 2003; Hansell et al., 2004), often due to a combination of photo-oxidation (Spencer et al., 2009), microbial degradation, and flocculation (Sholkovitz,
1978). Despite this, a portion of the terrigenous DOM can be transported offshore in many coastal regions (Vodacek et al., 1995; Bates and Hansell, 1999), escaping the continental margin (e.g., Fichot et al., 2014; Medeiros et al., 2015a) where it can be entrained in large scale ocean circulation and potentially contribute to the long-term storage of terrigenous production and to the millennial-aged DOM pool found in the deep ocean (Opsahl and Benner, 1997; Medeiros et al., 2016).

\section{OM Transport from Small Rivers and Groundwater}

The majority of studies on riverine OM export have focused on large river fluxes measured at gauging stations upstream of tidal influences (e.g., Hedges et al., 1986; Goñi et al., 1997; Bianchi et al., 2004). Although large rivers contribute significantly to global OM export, the integration of heterogeneous watershed characteristics such as vegetation, hydrology, and land management in large river channels makes it difficult to determine the relative importance of upland processes on $\mathrm{OM}$ export. Likewise, typical biomarkers have undergone extensive alteration prior to reaching large river channels as previously discussed. These issues are somewhat less problematic in streams and small rivers because watershed characteristics and hydrology responses are generally more homogeneous over smaller areas (Dalzell et al., 2005). Small rivers (i.e., basin area $<10,000 \mathrm{~km}^{2}$ ) have received attention as previously overlooked systems that export large quantities of organic carbon to the ocean (e.g., Milliman and Syvitski, 1992; Farnsworth and Milliman, 2003), and represent a direct connection between terrestrial and aquatic biospheres.

Small watersheds have less basin area for storing flood-driven sediments and are, thus, more likely to respond to event-driven floods (Milliman and Syvitski, 1992). The importance of floods in mobilizing allochthonous $\mathrm{OM}$ and its subsequent influence on heterotrophic productivity has been demonstrated in an Appalachian stream, where bacterial growth was $\sim 5$ times higher during a storm flow event compared to base flow discharge (Buffam et al., 2001). Different landscapes are functionalized during flooding events in small streams, resulting in a shift in terrestrial OM sources to receiving waters compared to base flow (Dalzell et al., 2005). Recent studies have focused on characterizing the OM transported by small systems draining both passive (Raymond and Bauer, 2001; Medeiros et al., 2012) and active margins (e.g., Komada et al., 2004; Leithold et al., 2006; Medeiros and Simoneit, 2008). In general, these investigations demonstrated that the export of predominantly aged POM is an important source of ancient sedimentary OM to ocean margins (Blair et al., 2003; Komada et al., 2004; Leithold et al., 2006).

Along coastlines, intertidal sediments and coastal wetlands are important land-sea interfaces (Figure 1.12). Groundwater fluxes and tide-driven outwelling are large sources of nutrients and OM to the coastal ocean (Kristensen et al., 2008; Moore, 2010). Permeable coastal sediments are controlled by surface flow-driven convection, waves, and tides. The resulting seawater circulation drives the rapid exchange of chemical species between the shallow sediments and the water column (Huettel et al., 
2014). High mineralization rates in sediments can cause a strong benthic-pelagic coupling of nutrient cycles (Rusch and Huettel, 2000; Gibbes et al., 2008; Røy et al., 2008). There is also accumulating evidence that reactive marine-derived $\mathrm{OM}$ is rapidly degraded in shallow permeable sediments (Huettel and Rusch, 2000; Ehrenhauss et al., 2004; Santos et al., 2009; Avery et al., 2012), which has led to their characterization as efficient biogeochemical filters for bioavailable compounds from coastal seawater (Rocha, 2008; Anschutz et al., 2009). However, submarine groundwater discharge from tidal flats and beaches to the coastal ocean also transports terrestrial DOM, a part of which may be relatively unreactive (Dittmar et al., 2012; Seidel et al., 2014, 2015b; Couturier et al., 2016).

Land and sea are further connected through subterranean estuaries, where fresh meteoric groundwater mixes with seawater that has entered the aquifer (Moore, 2010). Historically, the flow of coastal groundwater was considered to be low compared to rivers. Nutrient concentrations in groundwater, however, can exceed surface water concentrations and, thus, the supply of carbon and nutrients to the coastal ocean via submarine groundwater discharge can be regionally more important than the supply by rivers (Slomp and Van Cappellen, 2004; Moore et al., 2008). For example, groundwater fluxes and outwelling were found to be the dominant $\mathrm{OM}$ and nutrient sources to the adjacent water column in tidal flats, salt marshes, and mangroves (Moran et al., 1991; Dittmar et al., 2001; Moore et al., 2011; Medeiros et al., 2015b).

Distinguishing between surface and sub-surface sources of terrestrial $\mathrm{OM}$ is challenging and quantitative estimates of groundwater-driven fluxes of terrigenous DOM to the ocean are therefore still sparse, but the sub-surface fluxes are likely to be significant (Dittmar et al., 2001). For example, mangroves were estimated to be responsible for $>10 \%$ of the transport of lessreactive terrigenous DOM to the oceans, globally, although they cover less than $0.1 \%$ of the continents (Dittmar et al., 2006). Consequently, while submarine groundwater discharge has now been recognized as an important carrier of nutrients, its role on the export of less reactive terrigenous DOM to the global ocean remains largely unexplored. This is a difficult issue to address considering the utility of biomarker signatures becomes more obscure further along the aquatic continuum as physiochemical processing becomes more complex and heterogeneous.

\section{Estuarine OM Transport, Burial, and Transformation}

Coastal sediments store large amounts of OM, accounting for as much as $90 \%$ of the global burial of Holocene OM in the ocean (Berner, 1982; Hedges, 1992; Burdige, 2005). Fjords have been noted to be "hotspots" for the burial of terrestrially-derived OM due to their physical and biogeochemical characteristics (Hallet et al., 1996; Smittenberg et al., 2004; Nuwer and Keil, 2005; Hood and Scott, 2008; Walinsky et al., 2009; Hinojosa et al., 2014; Smith et al., 2015; Cui et al., 2016a). For example, it has been suggested that surface area-normalized OC burial rates are nearly 5 times greater in fjords than other marine systems and 100 times greater than the global ocean average (Smith et al., 2015). Sedimentation rates in fjords generally decrease from high to mid latitudes due to differences in watershed structure such as glaciated vs. nonglaciated and forested vs. bare bedrock land cover, with midlatitude fjords storing more terrestrial and marine derived $\mathrm{OM}$ relative to petrogenic OM compared to high-latitude fjords (Cui et al., 2016b).

Relatively little vascular plant-derived $\mathrm{OM}$ is exported to the ocean through fjords considering the high efficiency in sediment trapping (Syvitski et al., 1987) and a primary OM source from the watershed (Hood et al., 2009; Addison et al., 2013). The accumulation of petrogenic OM in fjords, on the other hand, is typically attributed to glacial denudation of sedimentary and metasedimentary rocks (Hallet et al., 1996). Vascular plant derived OM stored in fjord sediments is generally fresher and has a less degraded signature compared to OM stored in river-dominated shelf sediments (Goñi et al., 1998; Cui et al., 2016b). Regions with extensive coastal marshes, on the other hand, can export large amounts of vascular plant-derived OM originating from mangroves and grasses (Figure 1.10; Odum et al., 1979; Twilley, 1985). Fjords are further suspected to be important sinks of $\mathrm{CO}_{2}$ with respect to the global carbon cycle due to high rates of primary production and burial of autochthnous OM (Chmura et al., 2003). Along with fjords, large-river and small mountainous river-dominated continental margins represent the primary regions for OM deposition in the world's oceans (Blair and Aller, 2012; Smith et al., 2015). Largeriver open shelf settings, on the other hand, are the least efficient at burying OC most likely due to extensive oxidation prior to burial and respuspension/export processes (Galy et al., 2015). For example, terrestrially-derived OM burial decreases from 50\% in the Mackenzie River delta to less than 20\% in the Amazon River and Mississippi River deltas (Showers and Angle, 1986; de Haas et al., 2002; Cai and Lohrenz, 2010).

Chen and Borges (2009) estimated that $~ 70 \%$ of the POM exported from river systems must be remineralized in estuaries in order to support the global evasive $\mathrm{CO}_{2}$ flux based on an evaluation of the Amazon system by Keil et al. (1997) considering that only $10-50 \%$ of river-derived DOM was observed to be decomposed in estuaries (Moran et al., 1999; Raymond and Bauer, 2000; Abril et al., 2002). Cai (2011) suggests that the processing of this river-borne POM must occur primarily offshore in shelf sediments (Aller, 1998; Aller et al., 2004), rather than in the inner estuary for large river-influenced coastal systems, considering the short residence time for water in the inner plume. However, these assumptions are based on an incomplete knowledge of the flux of OM from large rivers. For example, for the Amazon River, most estimates of OM fluxes are based on data from Obidos, which is $800 \mathrm{~km}$ from the river mouth.

The first study to assess OM abundance and composition at the actual Amazon River mouth observed a 75\% decrease in particulate organic carbon (POC) and a $7.7 \%$ increase in DOC concentrations from the historic gauging station, Obidos, to the river mouth (Ward et al., 2015). OM is degraded quite rapidly with respect to transit times of several days to weeks in tropical regions such as the Amazon, where vascular plant derived DOM can be converted to $\mathrm{CO}_{2}$ on time scales ranging from minutes to 
hours (Ward et al., 2013, 2016). In addition to exporting OM, the Amazon River, and most rivers world-wide export large amounts of $\mathrm{CO}_{2}$ to estuaries and coastal oceans, which also supports estuarine $\mathrm{CO}_{2}$ outgassing. For example, $\mathrm{CO}_{2}$ levels are generally supersaturated in the inner plume, leading to degassing, whereas there is typically a net uptake of $\mathrm{CO}_{2}$ in the outer plume where primary production is stimulated due to river nutrient inputs and decreasing turbidity as sediments settle (Cooley et al., 2007; Subramaniam et al., 2008; Ibánhez et al., 2015). An important note is that none of these studies were able to resolve $\mathrm{CO}_{2}$ fluxes along the near-shore coastline or close to the actual zero salinity river endmember due to terrestrial contamination of remote sensing signals near the coast and a lack of measurements in the inner plume.

Two recent studies have evaluated the evolution of DOM composition along the river to plume continuum of the Amazon River based on ultra-high resolution mass spectrometry measurements performed along the continuum and after week-long dark incubations (Medeiros et al., 2015a; Seidel et al., 2015a). DOM composition patterns suggested continuous transformation of DOM via removal of oxygen-rich aromatic terrestrial DOM and a relative enrichment of more aliphatic microbial and marine compounds, with an overall decrease in molecular formulae complexity (Figure 5). This decrease in DOM complexity appears to be a common feature along river-ocean transects (Sleighter and Hatcher, 2008). The relative accumulation of highly unsaturated compounds (compounds present in both terrestrial and marine DOM; Figure 5D) can partly be explained by the microbial production of (semi)-refractory DOM, including carboxylic-rich alicyclic biomolecules, which is presumably stable for hundreds to thousands of years in the global ocean (Hertkorn et al., 2006; Hansell, 2013; Lechtenfeld et al., 2015; Osterholz et al., 2015). Most of the reactive DOM exported by the Amazon River is lost in the very early stages of the plume and a large fraction of the river DOM is transported through the plume unaltered. In rivers there is a constant input and recycling of reactive OM from the watershed and floodplains (Figure 4), but this source is cut off as soon as river water enters the ocean.

Microbial degradation, photo-oxidation, and dilution are generally the three main processes that control the composition of DOM in large river plumes (e.g., Medeiros et al., 2015a). Photo-oxidation is particularly important in the outer edges of river plumes where turbidity decreases, as well as in the open ocean (Wetzel et al., 1995; Kitidis et al., 2006; Gonsior et al., 2009; Stubbins et al., 2010, 2012b; Mopper et al., 2015). The fate of photo-oxidized DOM depends on temperature. For example, at lower temperatures DOM is generally oxidized directly into $\mathrm{CO}_{2}$, whereas at higher temperatures DOM is broken into intermediate molecules prior to mineralization into $\mathrm{CO}_{2}$ (Porcal et al., 2015). In some cases, the alteration of DOM molecular structure via photo-oxidation (e.g., Rodríguez-Zuniga et al., 2008) can result in enhanced biological decomposition (Tranvik and Bertilsson, 2001; Cory et al., 2007, 2014; Judd et al., 2007).

Microbial respiration, growth, and reproductive rates also respond to temperature, with warmer temperatures generally stimulating these processes (Gillooly et al., 2001, 2002; Brown et al., 2004). The response of aquatic ecosystems to warming temperatures is complicated, but is expected to greatly affect the rates and mechanisms for OM production and decomposition (Canuel et al., 2012). Some studies suggest that metabolism may be more impacted by varying temperatures compared to primary production under warming temperatures (LópezUrrutia et al., 2006), which could result in lower biomass yields throughout trophic levels along with altered microbial metabolic pathways and trophic linkages (Weston and Joye, 2005; Robador et al., 2010), particularly in waters affected by eutrophication (O'Connor et al., 2009). Alterations to the delivery, storage, processing, and transport of material through estuaries due to perturbations such as land use change and increased urbanization in watersheds are recorded in marine sediment records. For example, geochemical characteristics of sediments buried in Chesapeake Bay illustrate the ecosystem response to reductions in submerged aquatic plants (Orth and Moore, 1983), increased urbanization (Brush, 2009), increases in eutrophication and hypoxia, and decreases in fish stocks (http://chesapeakebay.net) over the last 50 years (Zimmerman and Canuel, 2002).

\section{CURRENT CARBON BUDGETS ACROSS THE CONTINUUM}

\section{Below-Ground Carbon Storage and Fluxes}

The largest reservoirs of stored OM are rocks, marine sediments, and soils, which store 70,000,000; 3000; and $2500 \mathrm{Pg} \mathrm{C}_{\text {year }}{ }^{-1}$, respectively (Hedges and Keil, 1995). Respiration within soils accounts for a large fraction of plant respiration, producing a flux of $\mathrm{CO}_{2}$ to the atmosphere of 68-77 Pg C year ${ }^{-1}$ (Raich and Schlesinger, 1992; Raich and Potter, 1995), which is greater than the 50-60 $\mathrm{Pg} \mathrm{C}_{\text {year }}{ }^{-1}$ flux from terrestrial net primary production (Field et al., 1998) and the flux of fresh litter to the soil surface (Matthews, 1997; Schlesinger and Andrews, 2000). Soil respiration is also linked to temperature (Davidson and Janssens, 2006; Feng et al., 2008; Li et al., 2008), and, as such, soil respiration rates are expected to increase under a warming climate, making the recycling of terrestrially-derived OM more efficient and limiting the amount of OM stored in soils over modern time scales (Kirschbaum, 1995; Jobbágy and Jackson, 2000). However, it is unclear how soil microbial community compositions will change in response to modified hydrologic regimes (e.g., wetter or drier) and the effect that this will have on soil OM decomposition rates and ultimately the ecosystem structure of river networks, whose micro-organisms are tightly linked to organisms present and mobilized from water-saturated soils.

Throughout the Holocene (e.g., the last $\sim 12,000$ years) roughly $420-820 \mathrm{Pg} \mathrm{C}$ has been stored in lake sediments, which is on the same order of magnitude as the amount of carbon stored in terrestrial biomass and soils (460-560 Pg C and $2500 \mathrm{Pg} \mathrm{C}$, respectively) (Sundquist, 1993; Hedges and Keil, 1995; Einsele et al., 2001; Cole et al., 2007). Lake and reservoir sediments in the conterminous U.S., alone, store $0.02 \mathrm{Pg} \mathrm{C}_{\mathrm{Cear}}{ }^{-1}$ and burial rates are directly linked to the type/size of the lake/reservoir; the abundance and sources of in situ OM; and land cover, 


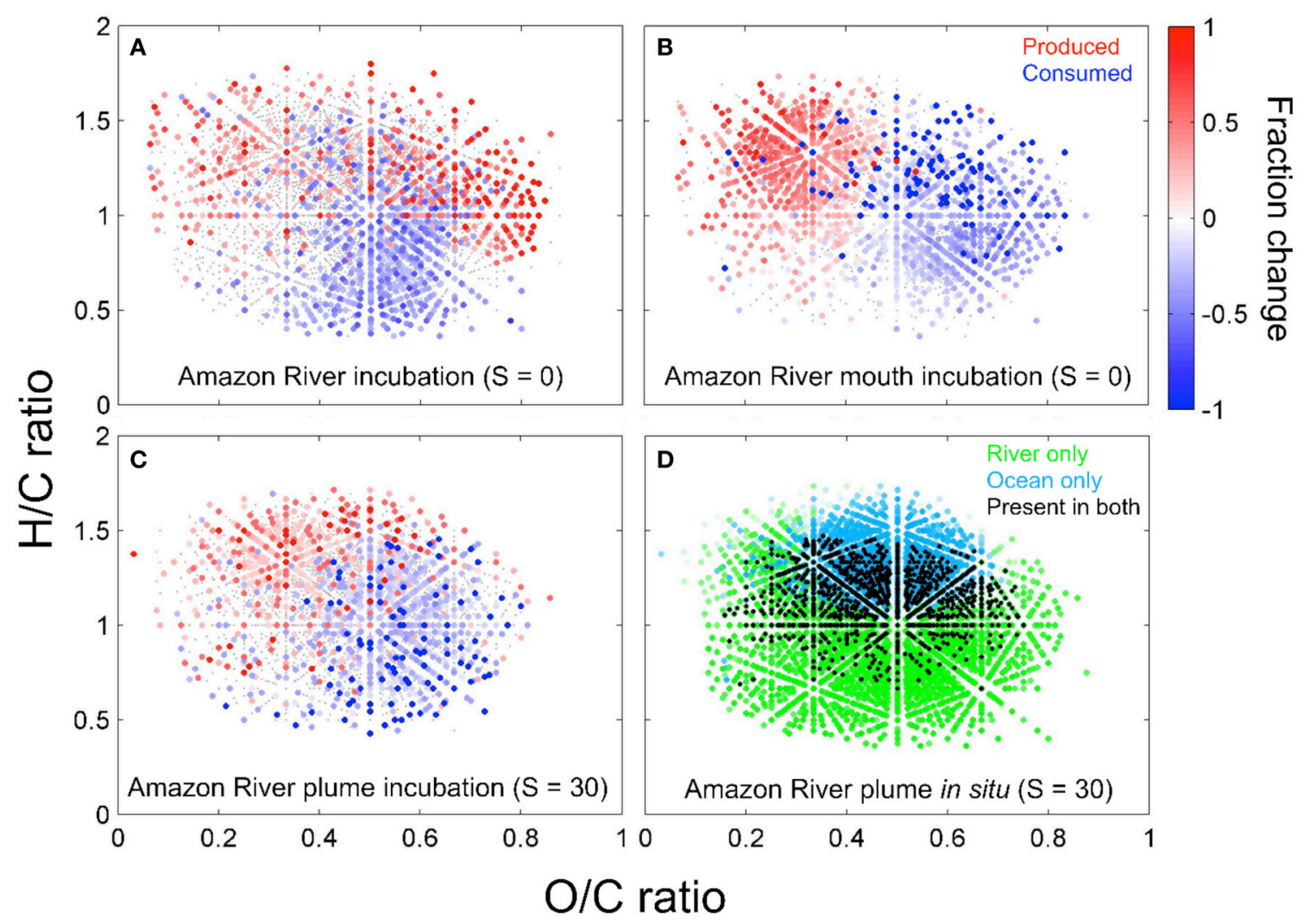

FIGURE 5 | The bio-transformation of DOM leaves distinct molecular imprints along the Amazon-River-to-ocean continuum. Van-Krevelen plots (hydrogen-to-carbon, $\mathrm{H} / \mathrm{C}$, and oxygen-to-carbon, $\mathrm{O} / \mathrm{C}$, ratios) reveal, which DOM molecular formulae changed significantly $(p \leq 0.05)$ in relative abundance in incubation experiments with water from the Amazon River (A), Amazon River mouth (B, both salinity =0), and Amazon River plume (C), salinity = 30). For these experiments, filtered water was incubated in the dark at ambient water temperature to determine the molecular fingerprints of microbial degradation. The color scale depicts the relative increase (red) or decrease (blue) of compounds after the incubation. The combination of bio- and photo-transformation leads to a decrease of molecular formulae richness and an increase of $\mathrm{H} / \mathrm{C}$ ratios of DOM along the river-to- ocean continuum (D), where the color-code depicts factor loadings from principal component (PC) analysis of compounds that were relatively enriched in the Amazon River (green) or the ocean (cyan) and compounds that were present in both (black) (modified from Medeiros et al., 2015a; Seidel et al., 2015a).

soil characteristics, and vegetation types in the surrounding watershed (Clow et al., 2015).

\section{Carbon Fluxes from Inland Waters}

Tranvik et al. (2009) modified the global inland water carbon budget presented by Cole et al. (2007), estimating that $1.4 \mathrm{Pg}$ $\mathrm{C}$ year $^{-1}$ is outgassed from inland waters (Figure 6). It was estimated that $0.9 \mathrm{Pg} \mathrm{C}_{\mathrm{year}}{ }^{-1}$ is delivered to the ocean, with 0.6 $\mathrm{Pg} \mathrm{C}$ year $^{-1}$ being stored in inland water systems. Raymond et al. (2013) updated the global inland waters $\mathrm{CO}_{2}$ emissions estimates, calculating a flux of 1.8 and $0.3 \mathrm{Pg} \mathrm{C}$ year $^{-1}$ for rivers and lakes, respectively (Figure 6). Roughly $75 \%$ of these emissions occur in the tropics, which only represent $\sim 35 \%$ of the terrestrial landscape. In productive tropical regions such as the Amazon, $\mathrm{CO}_{2}$ evasion from rivers can nearly match annual sequestration from the terrestrial biosphere (Richey et al., 2002). The global outgassing estimates by Raymond et al. (2013) excluded carbon remineralization in wetlands, for which more coarse data is available (Aufdenkampe et al., 2011). Wetlands are estimated to have an equivalent $\mathrm{CO}_{2}$ flux to the atmosphere of $2.1 \mathrm{Pg} \mathrm{C}_{\text {year }}{ }^{-1}$, which means that if export and storage terms are held constant, the terrestrial biosphere transports $\sim 5.7 \mathrm{Pg} \mathrm{C}_{\text {year }}{ }^{-1}$ through inland water and wetland systems, of which $74 \%$ is returned to the atmosphere (Wehrli, 2013; Le Quéré et al., 2015).

Estimates for $\mathrm{CO}_{2}$ evasion from inland waters and wetlands are the same order of magnitude as anthropogenic $\mathrm{CO}_{2}$ emissions from fossil fuel burning $\left(7.9 \pm 0.5 \mathrm{Pg} \mathrm{C}_{\text {year }}{ }^{-1}\right)$ and deforestation/land use change $\left(1.0 \pm 0.7 \mathrm{Pg} \mathrm{C}_{\mathrm{C}} \mathrm{yar}^{-1}\right)$, uptake of carbon in the oceans $\left(2.4 \pm 0.6 \mathrm{Pg} \mathrm{C}_{\text {year }}{ }^{-1}\right)$, and uptake of carbon by the terrestrial biosphere $\left(2.7 \pm 1.2 \mathrm{Pg} \mathrm{C}_{\mathrm{Cear}}{ }^{-1}\right)$ (Figure 6; Regnier et al., 2013). Regnier et al. (2013) estimated that $\sim 0.9 \mathrm{Pg} \mathrm{C}_{\text {year }}{ }^{-1}$ of the carbon taken up by the terrestrial biosphere is stored, however, recent higher estimates of $\mathrm{CO}_{2}$ outgassing from inland waters suggests that this storage term needs to be re-evaluated.

It is most likely that current global budgets underestimate the total flux of $\mathrm{CO}_{2}$ from inland waters to the atmosphere. For example, estimates for the Amazon River, which makes up 25\% of the current global $\mathrm{CO}_{2}$ flux from inland waters to the atmosphere (Raymond et al., 2013), are hypothesized to be underestimated 


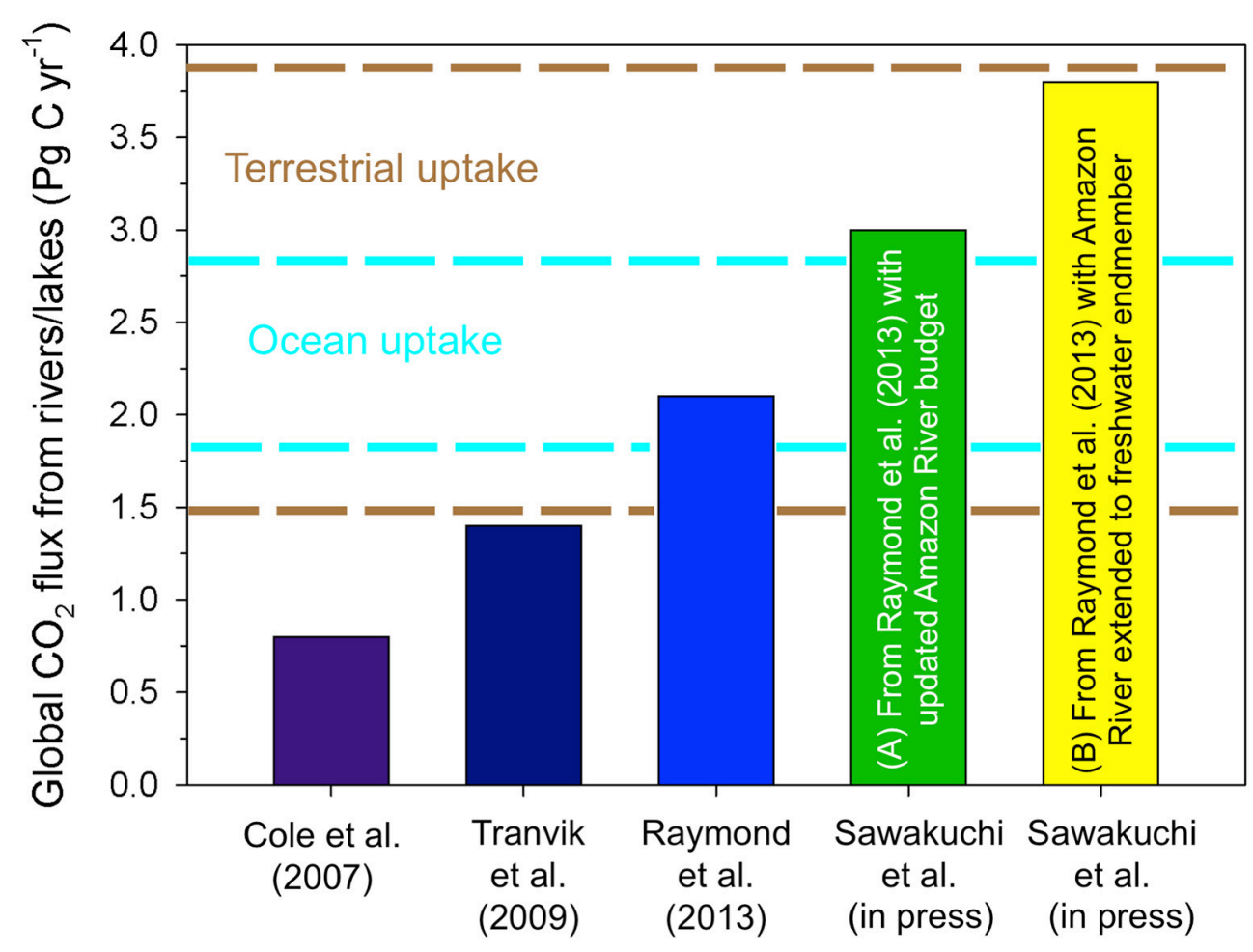

FIGURE 6 | Global estimates for the flux of $\mathrm{CO}_{2}$ from rivers and lakes to the atmosphere have substantially increased over the last decade. The most recent estimates by Sawakuchi et al. (in review) updated estimates of Raymond et al. (2013) to include more recent basin scale calculations for the Amazon River to include (A) the lower Amazon River and modified gas transfer coefficients for the upper and central Amazon (i.e., Rasera et al., 2013), and (B) extending calculations for the Amazon River to its offshore zero salinity endmember. It should be noted that these estimates do not include lower rivers and offshore freshwaters for other large systems, which will likely increase these estimates further. Dashed lines indicate estimates of the range of annual uptake of carbon by the terrestrial biosphere (brown) and the open ocean (cyan) (Regnier et al., 2013; Le Quéré et al., 2015).

based on conservative upscaling assumptions that did not account for the variability in gas exchange coefficients observed between small $(<100 \mathrm{~m})$ and large rivers $(>100 \mathrm{~m})$, which could considerably increase the previous estimate (Alin et al., 2011). With this in mind, Rasera et al. (2013) estimated that the Amazon River may outgas as much as $0.8 \mathrm{Pg} \mathrm{C}_{\text {year }}{ }^{-1}$, and including small streams could add another $0.1 \mathrm{Pg} \mathrm{C}$ year $^{-1}$ to this estimate (Johnson et al., 2008).

Neither the original estimate nor the most recent estimates for the Amazon River described above include the lower Amazon River, which extends $\sim 800 \mathrm{~km}$ downstream of Óbidos to the actual mouth and represents $\sim 13 \%$ of the basin's surface area (Ward et al., 2015). A recent study calculated that the lower reach of the Amazon River emits $0.5 \mathrm{Pg} \mathrm{C}_{\text {year }}{ }^{-1}$ (Sawakuchi et al., in review), which is equivalent to basin-scale budgets by Richey et al. (2002). When the lower river is included with the most recent upper/central Amazon River estimates (Johnson et al., 2008; Rasera et al., 2013), the basin-wide outgassing rate is $1.4 \mathrm{Pg}$ C year ${ }^{-1}$, which is 2.8 times higher than the estimates included in current global budgets (Figure 6; Richey et al., 2002; Raymond et al., 2013). Incorporating this new basin-wide budget into the global inland water budget results in a $44 \%$ increase in the global budget (3.0 Pg C year ${ }^{-1}$ ). Further, the completely freshwaters of the Amazon River extend an additional $60 \mathrm{~km}$ into the Atlantic
Ocean prior to mixing (Molinas et al., 2014), and if this region is included it could add an additional $0.8 \mathrm{Pg} \mathrm{C}_{\text {year }}{ }^{-1}$ to the Amazon River budget (Sawakuchi et al., in review). However, no observations have been made in this offshore region and it is not included in plume studies (Cooley et al., 2007; Subramaniam et al., 2008), revealing a critical gap in data coverage along the aquatic continuum, not just in the Amazon River, but rivers worldwide.

\section{Carbon Fluxes from Estuaries and Coastal Oceans}

Estuaries represent only $0.3 \%$ of the Earth's ocean-covered surface, compared to 7.2 and $92.5 \%$ for coastal shelves and open oceans, respectively (Woodwell et al., 1973; Walsh, 1988; Duarte et al., 2005; Bouillon et al., 2008). However, estuaries emit 0.25 Pg $\mathrm{C}$ year ${ }^{-1}$ of $\mathrm{CO}_{2}$ to the atmosphere, which is roughly equivalent to the amount of $\mathrm{CO}_{2}$ absorbed by continental shelves, and a similar order of magnitude as the amount of $\mathrm{CO}_{2}$ absorbed by the open ocean $\left(\sim 1.5 \mathrm{Pg} \mathrm{C}_{\text {year }}{ }^{-1}\right)$ (Borges et al., 2005; Cai et al., 2006; Chen and Borges, 2009; Takahashi et al., 2009).

Model estimates suggest that continental shelves were net heterotrophic prior to the industrial revolution, emitting $\mathrm{CO}_{2}$ to the atmosphere, and have since switched to a non-steady state supporting net autotrophy, perhaps due to an increase export of 


\section{In situ observations and experimentation}

\section{Inter-biome resolution}

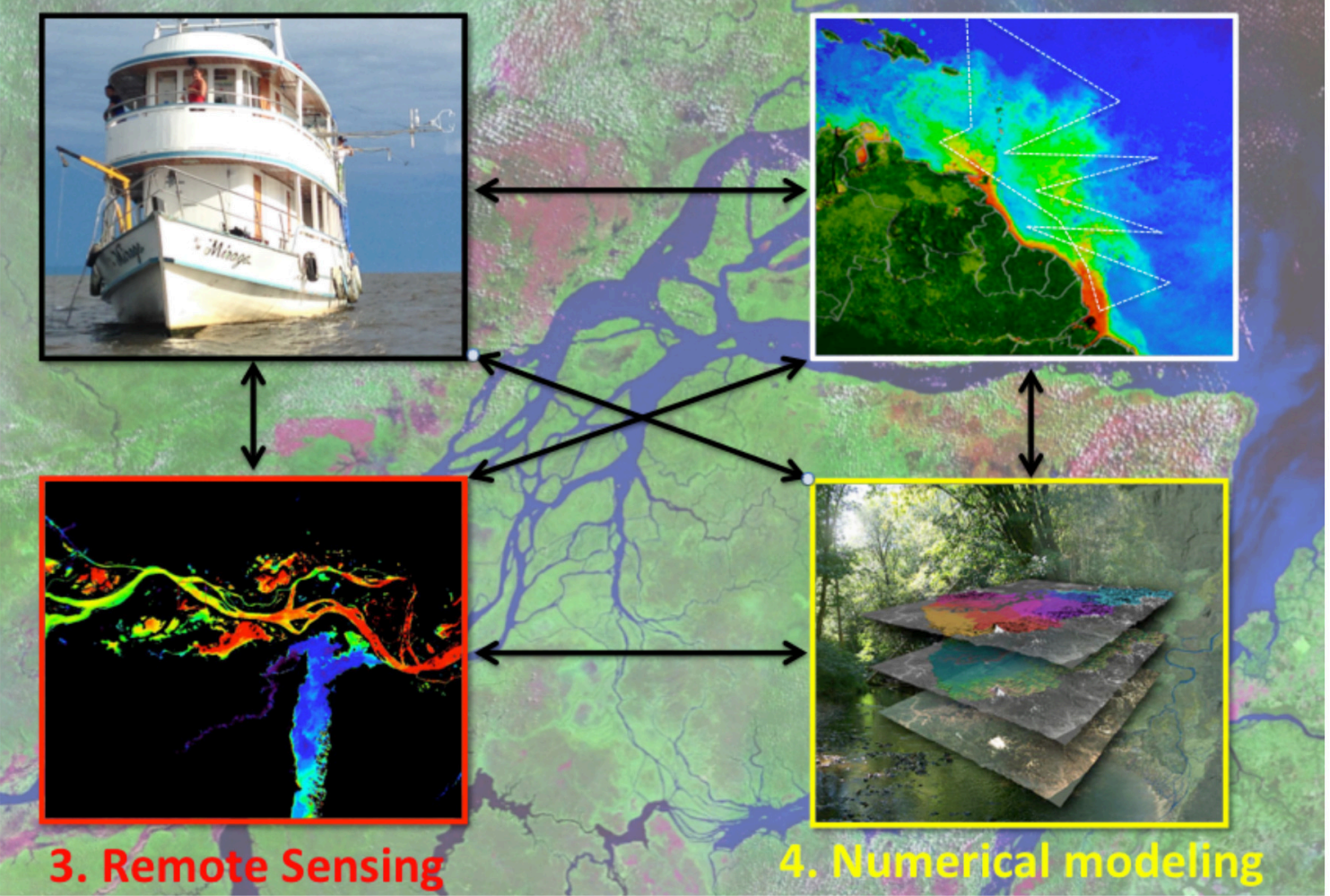

FIGURE 7 | Characterizing the evolution of biogeochemical constituents and processes along the aquatic continuum, from the terrestrial biosphere to the ocean, requires an integrative approach to characterizing spatiotemporal dynamics, defined here as the Environmental Coupled Observations (ECO) framework. In situ measurements and experimentation (1) made across traditional ecosystem boundaries (2) can be used to develop remote sensing algorithms (3) capable of resolving high-resolution spatiotemporal dynamics of ecosystem properties that can be optically parameterized. An empirically derived conceptual and quantitative understanding of the network of ecosystems across the continuum can then be described by coupled physical-biogeochemical models (4) to enable predictions of the sensitivity of modeled parameters to changes in forcings such as climate, land use, and infrastructure. Images courtesy NASA (2); Ward, unpublished (3); and UW Center for Environmental Visualizations (4).

nutrients to the ocean (Bauer et al., 2013). However, this trend may not actually result in enhanced carbon storage over longer timescales considering that calcification rates are expected to decrease with increasing $\mathrm{CO}_{2}$ concentrations in the atmosphere and oceans (Mackenzie et al., 2004). The mechanisms driving these coastal fluxes have been further expanded upon by Smith and Hollibaugh (1993), Wollast (1998), Ducklow and McCallister (2004), and others. Although in situ observations of $\mathrm{pCO}_{2}$ in rivers and oceans have increased over the last several decades, direct measurements are still sparse in low latitudes, particularly in the southern hemisphere (Borges, 2005; Zhai et al., 2007; Jiang et al., 2008; Guo et al., 2009).

\section{Limitations of Current Budgets}

The largest factors limiting our ability to accurately quantify global $\mathrm{CO}_{2}$ emissions from inland waters, estuaries, and coastal oceans is sparse coverage of actual direct measurements of $\mathrm{pCO}_{2}$ and difficulty in constraining gas transfer velocities (Regnier et al., 2013). Further, there are large gaps in our current coverage of $\mathrm{CO}_{2}$ flux estimates across the aquatic continuum with the entirety of the earth's surface not being accounted for, particularly along ecosystem transitions. For example, remote sensing-based studies of $\mathrm{CO}_{2}$ outgassing/uptake in large river plumes are unable to resolve regions of the plume near the coastline due to satellite-product land contamination. In the case of the Amazon River plume, water that is likely enriched in $\mathrm{CO}_{2}$ travels northward up the coastline with ocean currents and is not adequately accounted for. As these waters are increasingly included, plume $\mathrm{CO}_{2}$ budgets have changed from undersaturated (i.e., net uptake) to near equilibrium (Cooley et al., 2007; Ibánhez et al., 2015).

Underestimating surface area is also a problem within inland water systems. For example, previous basin-scale budgets for the Amazon, and most, if not all, large river systems, miss a large amount of surface area near the mouth and tidally-influenced reaches. Gas transfer velocities are among the most difficult parameters to constrain, particularly with sparse meteorological observations or direct flux measurements (Raymond et al., 2013). 
Gas transfer velocities in the lower reaches of large rivers have been shown to be much greater than further upstream due to large channel widths, long fetch, tidally-influenced current velocities, and stronger winds closer to the sea. Although $\mathrm{CO}_{2}$ concentrations may decrease along downstream gradients, these enhanced gas transfer velocities can result in equivalent or greater $\mathrm{CO}_{2}$ evasion rates in lower rivers compared to upstream (Sawakuchi et al., in review).

Estimates for $\mathrm{CO}_{2}$ outgassing/uptake in inland waters and estuaries have changed drastically over the last decade, essentially increasing by a factor of $\sim 2$ for each new rendition (Cole et al., 2007; Raymond et al., 2013), and this trend will likely continue into the near future based on the factors described above. There is still a long way to go in terms of simple accounting for inland waters (e.g., surface area and observations). Ocean carbon cycling budgets, on the other hand, have benefitted from more expansive observations and detailed statistical and modeling approaches that allow uncertainties to be identified and constrained (Cai, 2011) similar to the field of paleoclimatology, which has moved beyond exploratory observations and has identified and began constraining the major factors leading to uncertainty (Tierney and Tingley, 2014). This is a necessary progression for inland water studies.

\section{CONCLUDING REMARKS}

Characterizing the evolution of biogeochemical constituents and processes along the aquatic continuum, from the terrestrial biosphere to the ocean, requires an integrative approach to characterizing spatiotemporal dynamics, defined here as the Environmental Coupled Observations (ECO) framework (Figure 7). In situ observations and experimentation made across traditional ecosystem boundaries are at the core of this integrated approach.

Scientists have studied aquatic carbon cycling in regions near centers of human population such as North America and Europe quite extensively (e.g., Cai, 2011; Regnier et al., 2013), largely due to ease of access. However, many of the world's medium and large rivers are poorly characterized, particularly in the lower reaches where discharge becomes tidally-influenced (Ward et al., 2015). Achieving high temporal resolution in remote ecosystems is difficult due to the cost and effort required to accomplish large-scale research studies. In many cases it is only feasible for researchers to complete 1-2 research expeditions per year in remote locations. Funding is typically only available for three-year periods, meaning one study can only minimally characterize seasonal and inter-annual trends and often ignores rapid processes that can change by orders of magnitude in the course of minutes to hours during hydrologic events such as rainstorms or snow melting.

One solution to increasing temporal resolution is to build infrastructure and enhance the scientific capacity of local populations in regions of scientific interest. Training and deploying teams of citizen scientists is another invaluable approach to increasing both spatial and temporal resolution
(Silvertown, 2009). As bulk analyses become more feasible using simple and inexpensive probes or test strips, the utility of this approach will expand. Correlations between optical parameters and organic biomarker signatures is another way to gain useful insight on OM composition quickly and inexpensively. However, there is only so much that can be achieved by physically deploying humans into the field. As such, relating in situ observations with remote sensing products will push the boundaries of our ability to resolve spatiotemporal dynamics (Borges et al., 2005; Bauer et al., 2013). For example, chromophoric DOM (CDOM) is related to bulk DOC concentrations, and in some cases terrestriallyderived DOM, and can be visualized using ocean color sensors (Chaichitehrani et al., 2013; Tehrani et al., 2013; Joshi and D'Sa, 2015). Optical parameters can also prove useful for interpreting surface water quality in some cases (Singh et al., 2013). Resolving the surface area of inland waters is another important task that can be accomplished via remote sensing (e.g., Richey et al., 2002; Raymond et al., 2013) and more attention needs to be paid on the boundaries set for specific studies to ensure that the earth's surface is completely quantified. Improving algorithms to separate distinct parameters from remote sensing products is an essential step forward for the broader biogeochemistry field.

We live in an era where policy and development decisionmaking needs to be informed by an understanding of how earth systems function and interact, and also how these interactions will change under altered conditions. The development of numerical models based on an empirically derived conceptual and quantitative understanding of how ecosystems function is essential for predicting how coupled ecosystems across the terrestrial to marine continuum will respond to perturbations such as climate and land use change (e.g., Heffernan et al., 2014; Lauerwald et al., 2015). A key aspect of such an effort is bringing different research communities together to build coupled physical-biogeochemical-ecological models informed by real observations. Pushing the boundaries of this type of coupled observation-modeling framework is a critical step in constraining global carbon budgets and predicting the sensitivity of biogeochemical fluxes, ecosystem services, and ecosystem health to future change.

\section{AUTHOR CONTRIBUTIONS}

All authors listed, have made substantial, direct and intellectual contribution to the work, and approved it for publication.

\section{FUNDING}

This work was supported by funding from NSF DEB Grant \#1256724, FAPESP Grant \#08/58089-9, and the University of Florida Jon L. and Beverly A. Thompson Endowment.

\section{ACKNOWLEDGMENTS}

Figure 1 artwork was produced by Luk Cox 


\section{REFERENCES}

Abril, G., Guérin, F., Richard, S., Delmas, R., Galy-Lacaux, C., Gosse, P., et al. (2005). Carbon dioxide and methane emissions and the carbon budget of a 10-year old tropical reservoir (Petit Saut, French Guiana). Global Biogeochem. Cycles 19:GB4007. doi: 10.1029/2005GB002457

Abril, G., Martinez, J. M., Artigas, L. F., Moreira-Turcq, P., Benedetti, M. F., Vidal, L., et al. (2014). Amazon River carbon dioxide outgassing fuelled by wetlands. Nature. 505, 395-398. doi: 10.1038/nature12797

Abril, G., Nogueira, M., Etcheber, H., Cabeçadas, G., Lemaire, E., and Brogueira, M. J. (2002). Behaviour of organic carbon in nine contrasting European estuaries. Estuar. Coast. Shelf Sci. 54, 241-262. doi: 10.1006/ecss.2001.0844

Addison, J. A., Finney, B. P., Jaeger, J. M., Stoner, J. S., Norris, R. D., and Hangsterfer, A. (2013). Integrating satellite observations and modern climate measurements with the recent sedimentary record: an example from Southeast Alaska. J. Geophys. Res., Oceans. 118, 3444-3461. doi: 10.1002/jgrc.20243

Aiken, G. R., Spencer, R. G. M., Striegl, R. G., Schuster, P. F., and Raymond, P. A. (2014). Influences of glacier melt and permafrost thaw on the age of dissolved organic carbon in the Yukon River basin. Global Biogeochem. Cycles. 28, 525-537. doi: 10.1002/2013GB004764

Alcamo, J., Flörke, M., and Märker, M. (2007). Future long-term changes in global water resources driven by socio-economic and climatic changes. Hydrol. Sci. J. 52, 247-275. doi: 10.1623/hysj.52.2.247

Alin, S. R., Rasera, M. d. F. F. L., Salimon, C. I., Richey, J. E., Holtgrieve, G. W., Krusche A, V., et al. (2011). Physical controls on carbon dioxide transfer velocity and flux in low-gradient river systems and implications for regional carbon budgets. J. Geophys. Res. Biogeosci. 116:G01009. doi: 10.1029/2010JG001398

Aller, R. C. (1998). Mobile deltaic and continental shelf muds as suboxic, fluidized bed reactors. Mar. Chem. 61, 143-155. doi: 10.1016/s0304-4203(98)00024-3

Aller, R. C., Blair, N. E., Xia, Q., and Rude, P. D. (1996). Remineralization rates, recycling, and storage of carbon in Amazon shelf sediments. Cont. Shelf Res. 16, 753-786. doi: 10.1016/0278-4343(95)00046-1

Aller, R. C., Heilbrun, C., Panzeca, C., Zhu, Z., and Baltzer, F. (2004). Coupling between sedimentary dynamics, early diagenetic processes, and biogeochemical cycling in the Amazon-Guianas mobile mud belt: coastal French Guiana. Mar. Geol. 208:331. doi: 10.1016/j.margeo.2004. 04.027

Alley, W. M. (2006). Tracking U.S. groundwater reserves for the future? Environment 48, 10-25. doi: 10.3200/ENVT.48.3.10-25

Anderson, N. J., Bennion, H., and Lotter, A. F. (2014). Lake eutrophication and its implications for organic carbon sequestration in Europe. Global Chang. Biol. 20, 2741-2751. doi: 10.1111/gcb.12584

Anderson, N. J., Dietz, R. D., and Engstrom, D. R. (2013). Land-use change, not climate, controls organic carbon burial in lakes. Proc. R. Soc. Lond. B Biol. Sci. 280:20131278. doi: 10.1098/rspb.2013.1278

Anschutz, P., Smith, T., Mouret, A., Deborde, J., Bujan, S., Poirier, et al. (2009). Tidal sands as biogeochemical reactors. Estuar. Coast. Shelf Sci. 84, 84-90. doi: 10.1016/j.ecss.2009.06.015

Arnarson, T. S., and Keil, R. G. (2007). Changes in organic matter-mineral interactions for marine sediments with varying oxygen exposure times. Geochim. Cosmochim. Acta 71, 3545-3556. doi: 10.1016/j.gca.2007.04.027

Artaxo, P., Storms, H., Bruynseelsa, F., and Rieken, R. V. (1988). Composition and sources of aerosols from the Amazon Basin. J. Geophys. Res. 93, 1605-1615. doi: 10.1029/JD093iD02p01605

Aufdenkampe, A. K., Hedges, J. I., Richey, J. E., Krusche, A. V., and Llerena, C. A. (2001). Sorptive fractionation of dissolved organic nitrogen and amino acids onto fine sediments within the Amazon basin. Limnol. Oceanogr. 46, 1921-1935. doi: 10.4319/lo.2001.46.8.1921

Aufdenkampe, A. K., Mayorga, E., Raymond, P. A., Melack, J. M., Doney, S. C., Alin, S. R., et al. (2011). Riverine coupling of biogeochemical cycles between land, oceans, and atmosphere. Front. Ecol. Environ. 9, 53-60. doi: $10.1890 / 100014$

Avery, G. B. Jr., Kieber, R. J., Taylor, K. J., and Dixon, J. L. (2012). Dissolved organic carbon release from surface sand of a high energy beach along the Southeastern Coast of North Carolina, USA. Mar. Chem. 132-133, 23-27. doi: 10.1016/j.marchem.2012.01.006
Baker, M. A., Valett, H. M., and Dahm, C. N. (2000). Organic carbon supply and metabolism in a shallow groundwater ecosystem. Ecology 81, 3133-3148. doi: 10.1890/0012-9658(2000)081[3133:OCSAMI]2.0.CO;2

Baldock, J. A., Masiello, C. A., Gelinas, Y., and Hedges, J. I. (2004). Cycling and composition of organic matter in terrestrial and marine ecosystems. Mar. Chem. 92, 39-64. doi: 10.1016/j.marchem.2004.06.016

Barbier, E. B., Hacker, S. D., Kennedy, C., Koch, E. W., Stier, A. C., and Silliman, B. R. (2011). The value of estuarine and coastal ecosystem services. Ecol. Monogr. 81, 169-193. doi: 10.1890/10-1510.1

Bastviken, D., Cole, J. J., Pace, M. L., and Van de Bogert, M. C. (2008). Fates of methane from different lake habitats: connecting whole-lake budgets and $\mathrm{CH} 4$ emissions. J. Geophys. Res. Biogeosci. 113:G02024. doi: 10.1029/2007JG000608

Bastviken, D., Cole, J., Pace, M., and Tranvik, L. (2004). Methane emissions from lakes: dependence of lake characteristics, two regional assessments, and a global estimate. Global Biogeochem. Cycles 18:GB4009. doi: 10.1029/2004GB002238

Bastviken, D., Tranvik, L. J., Downing, J. A., Crill, P. M., and Enrich-Prast, A. (2011). Freshwater methane emissions offset the continental carbon sink. Science 331:50. doi: 10.1126/science.1196808

Bates, N., and Hansell, D. (1999). A high resolution study of surface layer hydrographic and biogeochemical properties between Chesapeake Bay and Bermuda. Mar. Chem. 67, 1-16. doi: 10.1016/S0304-4203(99)00045-6

Battin, T. J., Kaplan, L. A., Findlay, S., Hopkinson, C. S., Marti, E., Packman, A. I., et al. (2008). Biophysical controls on organic carbon fluxes in fluvial networks. Nat. Geosci. 1, 95-100. doi: 10.1038/ngeo101

Bauer, J. E., Cai, W. J., Raymond, P. A., Bianchi, T. S., Hopkinson, C. S., and Regnier, P. A. G. (2013). The changing carbon cycle of the coastal ocean. Nature 504, 61-70. doi: 10.1038/nature12857

Bédard, C., and Knowles, R. (1991). Hypolimnetic $\mathrm{O}_{2}$ consumtion, denitrification, and methanogenesis in a thermally stratified lake, Can. J. Fish. Aquat. Sci. 48, 1048-1054. doi: 10.1139/f91-123

Benedetti, M. F., Mounier, S., Filizola, N., Benaim, J., and Seyler, P. (2003). Carbon and metal concentrations, size distributions and fluxes in major rivers of the Amazon basin. Hydrol. Process. 17, 1363-1377. doi: 10.1002/hyp.1289

Bengtsson, M. M., Wagner, K., Burns, N. R., Herberg, E. R., Wanek, W., Kaplan, L. A., et al. (2014). No evidence of aquatic priming effects in hyporheic zone microcosms. Sci. Rep. 4:5187. doi: 10.1038/srep05187

Benke, A. C., and Meyer, J. L. (1988). "Structure and function of a Blackwater River in the Southeastern U. S. A," in Internationale Vereinigung fuer Theoretische und Angewandte Limnologie, Vol. 23 (Stuttgart: Verhandlungen IV TLAP).

Bergström, I., Mäkelä, S., Kankaala, P., and Kortelainen, P. (2007). Methane efflux from littoral vegetation stands of southern boreal lakes: an upscaled regional estimate. Atmos. Environ. 41, 339-351. doi: 10.1016/j.atmosenv.2006.08.014

Berner, R. A. (1982). Burial of organic carbon and pyrite sulfur in the modern ocean: its geochemical and environmental significance. Am. J. Sci. 282, 451-473. doi: 10.2475/ajs.282.4.451

Berner, R. A. (2004). The Phanerozoic Carbon Cycle: $\mathrm{CO}_{2}$ and $\mathrm{O}_{2}$. Oxford: Oxford University Press.

Bianchi, T. S. (2011). The role of terrestrially derived organic carbon in the coastal ocean: a changing paradigm and the priming effect. Proc. Natl. Acad. Sci. U.S.A. 108, 19473-19481. doi: 10.1073/pnas.1017982108

Bianchi, T. S., and Allison, M. A. (2009). Large-river delta-front estuaries as natural "recorders" of global environmental change. Proc. Nat. Acad. Sci. U.S.A. 106, 8085-8092. doi: 10.1073/pnas.0812878106

Bianchi, T. S., Allison, M. A., Canuel, E. A., Corbett, D. R., McKee, B. A., Sampere, T. P., et al. (2006). Rapid export of organic matter to the Mississippi Canyon. Eos Trans. Am. Geophys. Union 87, 565-573. doi: 10.1029/2006EO 500002

Bianchi, T. S., Filley, T., Dria, K., and Hatcher, P. G. (2004). Temporal variability in sources of dissolved organic carbon in the lower Mississipi River. Geochim. Cosmochim. Acta 68, 959-967. doi: 10.1016/j.gca.2003.07.011

Bianchi, T. S., Thornton, D., Yvon-Lewis, S., King, G., Eglinton, T., Shields, M. R. et al. (2015). Positive priming of terrestrially-derived dissolved organic matter in a freshwater microcosm system. Geophys. Res. Lett. 42, 5460-5467. doi: $10.1002 / 2015 \mathrm{gl} 064765$

Blair, N. E., and Aller, R. C. (2012). The fate of terrestrial organic carbon in the marine environment. Annu. Rev. Mar. Sci. 4, 401-423. doi: 10.1146/annurev-marine-120709-142717 
Blair, N. E., Leithold, E. L., Ford, S. T., Peeler, K. A., Holmes, J. C., and Perkey, D. W. (2003). The persistence of memory: the fate of ancient sedimentary organic carbon in a modern sedimentary system. Geochim. Cosmochim. Acta 67, 63-73. doi: 10.1016/S0016-7037(02)01043-8

Blazejewski, G. A., Stolt, M. H., Gold, A. J., Gurwick, N., and Groffman, P. M. (2009). Spatial distribution of carbon in the subsurface of riparian zones. Soil Sci. Soc. Am. J. 73, 1733-1740. doi: 10.2136/sssaj2007.0386

Boon, P. I., and Mitchell, A. (1995). Methanogenesis in the sediments of an Australian freshwater wetland: comparison with aerobic decay, and factors controlling methanogenesis. FEMS Microbiol. Ecol. 18, 175-190. doi: 10.1111/j.1574-6941.1995.tb00175.x

Borges, A., Delille, B., and Frankignoulle, M. (2005). Budgeting sinks and sources of $\mathrm{CO}_{2}$ in the coastal ocean: diversity of ecosystems counts. Geophys. Res. Lett. 32:L14601. doi: 10.1029/2005GL023053

Borges, A. V. (2005). Do we have enough pieces of the jigsaw to integrate $\mathrm{CO}_{2}$ fluxes in the coastal ocean? Estuaries 28, 3-27. doi: 10.1007/BF02732750

Borges, A. V., and Abril, G. (2011). "Carbon dioxide and methane dynamics in estuaries," In Treatise on Estuarine and Coastal Science, Vol. 2011 eds E. Wolanski, and D. McLusky (Waltham, MA: Academic Press), 119-161. doi: 10.1016/B978-0-12-374711-2.00504-0

Borges, A. V., Abril, G., Darchambeau, F., Teodoru, C. R., Deborde, J., Vidal, L. O., et al. (2015). Divergent biophysical controls of aquatic $\mathrm{CO}_{2}$ and $\mathrm{CH}_{4}$ in the World's two largest rivers. Sci. Rep. 5:15614. doi: 10.1038/srep15614

Bose, S. K., Francis, R. C., Govender, M., Bush, T., and Spark, A. (2009). Lignin content versus syringyl to guaiacyl ratio amongst poplars. Bioresour. Technol.. 100, 1628-1633 doi: 10.1016/j.biortech.2008.08.046

Bouillon, S., Borges, A. V., Castañeda-Moya, E., Diele, K., Dittmar, T., Duke, N. C., et al. (2008). Mangrove production and carbon sinks: a revision of global budget estimates. Global Biogeochem. Cycles 22:GB2013. doi: 10.1029/2007GB003052

Boulton, A. J., Findlay, S., Marmonier, P., Stanley, E. H., and Valett, H. M. (1998). The functional significance of the hyporheic zone. Annu. Rev. Ecol. Syst. 29, 59-81. doi: 10.1146/annurev.ecolsys.29.1.59

Boyer, E. W., Hornberger, G. M., Bencala, K. E., and McKnight, D. M. (1997). Response characteristics of DOC flushing in an alpine catchment. Hydrol. Process. 11, 1635-1647. doi: 10.1002/(SICI)1099-1085(19971015)11:12<1635:: AID-HYP494>3.0.CO;2-H

Brown, J. H., Gillooly, J. F., Allen, A. P., Savage, V. M., and West, G. B. (2004). Toward a metabolic theory of ecology. Ecology 85, 1771-1789. doi: 10.1890/03-9000

Brunke, M., and Gonser, T. O. M. (1997). The ecological significance of exchange processes between rivers and groundwater. Freshw. Biol. 37, 1-33. doi: 10.1046/j.1365-2427.1997.00143.x

Brush, G. (2009). Historical land use, nitrogen, and coastal eutrophication: a paleoecological perspective. Estuaries Coasts. 32, 18-28. doi: $10.1007 /$ s12237-008-9106-Z

Buffam, I., Galloway, J. N., Blum, L. K., and McGlathery, K. J. (2001). A stormflow/baseflow comparison of dissolved organic matter concentrations and bioavailability in an Appalachian stream. Biogeochemistry 53, 269-306. doi: 10.1023/A:1010643432253

Burdige, D. J. (2005). Burial of terrestrial organic matter in marine sediments: a reassessment. Global Biogeochem. Cycles 19:GB4011. doi: 10.1029/2004gb002368

Burdige, D. J. (2007). Preservation of organic matter in marine sediments: controls, mechanisms, and an imbalance in sediment organic carbon budgets? Chem. Rev. 107, 467-485. doi: 10.1021/cr050347q

Butman, D., and Raymond, P. A. (2011). Significant efflux of carbon dioxide from streams and rivers in the United States. Nat. Geosci. 4, 839-842. doi: 10.1038/ngeo1294

Butman, D. E., Wilson, H. F., Barnes, R. T., Xenopoulos, M. A., and Raymond, P. A. (2015). Increased mobilization of aged carbon to rivers by human disturbance. Nat. Geosci. 8, 112-116. doi: 10.1038/ngeo2322

Cai, W. J. (2011). Estuarine and coastal ocean carbon paradox: $\mathrm{CO}_{2}$ sinks or sites of terrestrial carbon incineration? Ann. Rev. Mar. Sci. 3, 123-145. doi: 10.1146/annurev-marine-120709-142723

Cai, W.-J., Dai, M., and Wang, Y. (2006). Air-sea exchange of carbon dioxide in ocean margins: a province-based synthesis. Geophys. Res. Lett. 33:L12603. doi: $10.1029 / 2006 \mathrm{gl} 026219$

Cai, W.-J., and Lohrenz, S. (2010). "Carbon, nitrogen, and phosphorus fluxes from the Mississippi River and the transformation and fate of biological elements in the river plume and the adjacent margin," in Carbon and Nutrient Fluxes in Continental Margins: A Global Synthesis, eds K.-K. Liu, L. Atkinson, R. Quinones, and L. Talaue-McManus (Berlin: Springer), 123-145.

Canals, M., Puig, P., de Madron, X. D., Heussner, S., Palanques, A., and Fabres, J. (2006). Flushing submarine canyons. Nature 444, 354-357. doi: 10.1038/nature05271

Canuel, E. A., Cammer, S. S., McIntosh, H. A., and Pondell, C. R. (2012). Climate change impacts on the organic carbon cycle at the land-ocean interface. Annu. Rev. Earth Planet. Sci. 40, 685-711. doi: 10.1146/annurev-earth-042711-105511

Catalán, N., Kellerman, A. M., Peter, H., Carmona, F., and Tranvik, L. J. (2015). Absence of a priming effect on dissolved organic carbon degradation in lake water. Limnol. Oceanogr. 60, 159-168. doi: 10.1002/lno.10016

Catalán, N., Marcé, R., Kothawala, D. N., and Tranvik, L. J. (2016). Organic carbon decomposition rates controlled by water retention time across inland waters. Nat. Geosci. 9, 501-504. doi: 10.1038/ngeo2720

Chaichitehrani, N., D’Sa, E. J., Ko, D. S., Walker, N. D., Osburn, C. L., and Chen, R. F. (2013). Colored dissolved organic matter dynamics in the northern Gulf of Mexico from ocean color and numerical model results. J. Coast. Res. 30, 800-814. doi: 10.2112/JCOASTRES-D-13-00036.1

Chapelle, F. H., Bradley, P. M., Goode, D. J., Tiedeman, C., Lacombe, P. J., Kaiser, K., et al (2009). Biochemical indicators for the bioavailability of organic carbon in ground water. Groundwater 47, 108-121. doi: 10.1111/j.1745-6584.2008.00493.x

Chen, C. T. A., and Borges, A. V. (2009). Reconciling opposing views on carbon cycling in the coastal ocean: continental shelves as sinks and near-shore ecosystems as sources of atmospheric $\mathrm{CO}_{2}$. Deep Sea Res. Part Top. Stud. Oceanogr. 56, 578-590. doi: 10.1016/j.dsr2.2009.01.001

Chmura, G. L., Anisfeld, S. C., Cahoon, D. R., and Lynch, J. C. (2003). Global carbon sequestration in tidal, saline wetland soils. Global Biogeochem. Cycles 17:1111. doi: 10.1029/2002gb001917

Clinton, S. M., Edwards, R. T., and Naiman, R. J. (2002). Forest-river interactions: influence on hyporheic dissolved organic carbon concentrations in a floodplain terrace. J. Am. Water Resour. Assoc. 38, 619-631. doi: 10.1111/j.1752-1688.2002.tb00984.x

Clow, D. W., Stackpoole, S. M., Verdin, K. L., Butman, D. E., Zhu, Z., Krabbenhoft, D. P., et al. (2015). Organic carbon burial in lakes and reservoirs of the conterminous United States. Environ. Sci. Technol. 49, 7614-7622. doi: 10.1021/acs.est.5b00373

Cole, J. J., Caraco, N. F., Kling, G. W., and Kratz, T. K. (1994). Carbon dioxide supersaturation in the surface waters of lakes. Science 265, 1568-1569. doi: $10.1126 /$ science.265.5178.1568

Cole, J. J., Prairie, Y. T., Caraco, N. F., McDowell, W. H., Tranvik, L. J., Striegl, R. G., et al. (2007). Plumbing the global carbon cycle: integrating inland waters into the terrestrial carbon budget. Ecosystems 10, 172-185. doi: 10.1007/s10021-006-9013-8

Coleman, J. M., Walker, H. J., and Grabau, W. E. (1998). Sediment instability in the Mississippi River delta. J. Coas. Res. 872-881.

Cooley, S. R., Coles, V. J., Subramaniam, A., and Yager, P. L. (2007). Seasonal variations in the Amazon plume-related atmospheric carbon sink. Global Biogeochem. Cycles 21, 1-15. doi: 10.1029/2006GB002831

Cory, R. M., McKnight, D. M., Chin, Y. P., Miller, P., and Jaros, C. L. (2007). Chemical characteristics of fulvic acids from Arctic surface waters: microbial contributions and photochemical transformations. J. Geophys. Res. Biogeosci. 112:G04S51. doi: 10.1029/2006JG000343

Cory, R. M., Ward, C. P., Crump, B. C., and Kling, G. W. (2014). Sunlight controls water column processing of carbon in arctic fresh waters. Science 345, 925-928. doi: 10.1126/science.1253119

Couturier, M., Nozais, C., and Chaillou, G. (2016). Microtidal subterranean estuaries as a source of fresh terrestrial dissolved organic matter to the coastal ocean. Mar. Chem. 186, 46-57. doi: 10.1016/j.marchem.2016. 08.001

Crawford, J. T., Loken, L. C., Stanley, E. H., Stets, E. G., Dornblaser, M. M. and Striegl, R. G. (2016). Basin scale controls on $\mathrm{CO}_{2}$ and $\mathrm{CH}_{4}$ emissions from the Upper Mississippi River. Geophys. Res. Lett. 43, 1973-1979. doi: 10.1002/2015GL067599

Crawford, J. T., and Stanley, E. H. (2016). Controls on methane concentrations and fluxes in streams draining human-dominated landscapes. Ecol. Appl. 26, 1581-1591. doi: 10.1890/15-1330 
Creed, I. F., McKnight, D. M., Pellerin, B. A., Green, M. B., Bergamaschi, B. A., Aiken, G. R., et al. (2015). The river as a chemostat: fresh perspectives on dissolved organic matter flowing down the river continuum. Can. J. Fish. Aquat. Sci. 72, 1272-1285. doi: 10.1139/cjfas-2014-0400

Cui, X., Bianchi, T. S., Hutchings, J. A., Savage, C., and Curtis, J. H. (2016a). Partitioning of organic carbon among density fractions in surface sediments of Fiordland, New Zealand. J. Geophys. Res. Biogeosci. 121, 1016-1031. doi: 10.1002/2015JG003225

Cui, X., Bianchi, T. S., Jaeger, J. M., and Smith, R. W. (2016b). Biospheric and petrogenic organic carbon flux along southeast Alaska. Earth Planet. Sci. Lett. 452, 238-246. doi: 10.1016/j.epsl.2016.08.002

Curry, C. L. (2007). Modeling the soil consumption of atmospheric methane at the global scale. Global Biogeochem. Cycles 21, GB4012. doi: 10.1029/2006GB 002818

Dalzell, B. J., Filley, T. R., and Harbor, J. M. (2005). Flood pulse influences on terrestrial organic matter export from an agricultural watershed. J. Geophys. Res. 110:G02011. doi: 10.1029/2005JG000043

Davidson, E. A., and Janssens, I. A. (2006). Temperature sensitivity of soil carbon decomposition and feedbacks to climate change. Nature 440, 165-173. doi: $10.1038 /$ nature 04514

Davis, A. P., Shokouhian, M., and Ni, S. (2001). Loading estimates of lead, copper, cadmium, and zinc in urban runoff from specific sources. Chemosphere 44, 997-1009. doi: 10.1016/S0045-6535(00)00561-0

Dean, W. E., and Gorham, E. (1998). Magnitude and significance of carbon burial in lakes, reservoirs, and peatlands. Geology 26, 535-538. doi: 10.1130/0091-7613(1998)026<0535:MASOCB >2.3.CO;2

de Haas, H., van Weering, T. C. E., and de Stigter, H. (2002). Organic carbon in shelf seas: sinks or sources, processes and products. Cont. Shelf Res. 22, 691-717. doi: 10.1016/S0278-4343(01)00093-0

Delsontro, T., McGinnis, D. F., Sobek, S., Ostrovsky, I., and Wehrli, B. (2010). Extreme methane emissions from a Swiss hydropower reservoir: contribution from bubbling sediments. Environ. Sci. Technol. 44, 2419-2425. doi: $10.1021 /$ es9031369

Diaz, R. J., and Rosenberg, R. (2008). Spreading dead zones and consequences for marine ecosystems. Science 321, 926-929. doi: 10.1126/science.1156401

Dittmar, T. (2015). "Reasons behind the long-term stability of dissolved organic matter," in Biogeochemistry of Marine Dissolved Organic Matter, eds D. A. Hansell and C. A. Carlson (London: Elsevier), 369-388.

Dittmar, T., Hertkorn, N., Kattner, G., and Lara, R. J. (2006). Mangroves, a major source of dissolved organic carbon to the oceans. Global Biogeochem. Cycles 20:GB1012. doi: 10.1029/2005GB002570

Dittmar, T., and Kattner, G. (2003). The biogeochemistry of the river and shelf ecosystem of the Arctic Ocean: a review. Mar. Chem. 83, 103-120. doi: 10.1016/S0304-4203(03)00105-1

Dittmar, T., Lara, R. J., and Kattner, G. (2001). River or mangrove? Tracing major organic matter sources in tropical Brazilian coastal waters. Mar. Chem. 73, 253-271. doi: 10.1016/s0304-4203(00)00110-9

Dittmar, T., Paeng, J., Gihring, T., Suryaputra, I. G. N. A., and Huettel, M. (2012). Discharge of dissolved black carbon from a fire-affected intertidal system. Limnol. Oceanogr. 57, 1171-1181. doi: 10.4319/lo.2012.57.4.1171

Döll, P. (2009). Vulnerability to the impact of climate change on renewable groundwater resources: a global-scale assessment. Environ. Res. Lett. 4:035006. doi: 10.1088/1748-9326/4/3/035006

Downing, J. A., Prairie, Y. T., Cole, J. J., Duarte, C. M., Tranvik, L. J., Striegl, R. G., et al. (2006). The global abundance and size distribution of lakes, ponds, and impoundments. Limnol. Oceanogr. 51, 2388-2397. doi: 10.4319/lo.2006.51.5.2388

Duan, S. W., He, Y., Kaushal, S. S., Bianchi, T. S., Ward, N. D., Guo, L., et al. (2017). Impact of wetland distribution on decreasing dissolved organic carbon concentrations along the Mississippi River continuum. Front. Mar. Sci. 3:280. doi: 10.3389/fmars.2016.00280

Duarte, C. M., Middelburg, J. J., and Caraco, N. (2005). Major role of marine vegetation on the oceanic carbon cycle. Biogeosciences 2, 1-8. doi: 10.5194/bg-2-1-2005

Duarte, C. M., and Prairie, Y. T. (2005). Prevalence of heterotrophy and atmospheric $\mathrm{CO}_{2}$ emissions from aquatic ecosystems. Ecosystems 8, 862-870. doi: 10.1007/s10021-005-0177-4
Ducklow, H. W., and McCallister, S. L. (2004). "The biogeochemistry of carbon dioxide in the coastal oceans," in The Sea, eds A. R. Robinson, and K. Brink (Cambridge: Harvard University Press), 269-315.

Dugan, J. E., Defeo, O., Jaramillo, E., Jones, A. R., Lastra, M., Nel, R., et al. (2010). Give beach ecosystems their day in the sun. Science 329, 1146. doi: 10.1126/science.329.5996.1146-a

Easthouse, K. B., Mulder, J., Christophersen, N., and Seip, H. M. (1992). Dissolved organic carbon fractions in soil and stream water during variable hydrologic conditions at Birkenes, Southern Norway. Water Resour. Res. 28, 1585-1596. doi: 10.1029/92WR00056

Ehrenhauss, S., Witte, U., Janssen, F., and Huettel, M. (2004). Decomposition of diatoms and nutrient dynamics in permeable North Sea sediments. Cont. Shelf Res. 24, 721-737. doi: 10.1016/j.csr.2004.01.002

Einsele, G., Yan, J., and Hinderer, M. (2001). Atmospheric carbon burial in modern lake basins and its significance for the global carbon budget. Global Planet Change 30, 167-195. doi: 10.1016/S0921-8181(01)00105-9

Famiglietti, J. S. (2014). The global groundwater crisis, Nat. Clim. Change 4, 945-948. doi: 10.1038/nclimate2425

Farnsworth, K. L., and Milliman, J. D. (2003). Effects of climatic and anthropogenic change on small mountainous rivers: the Salinas River example. Global Planet Change 39, 53-64. doi: 10.1016/S0921-8181(03)00017-1

Fearnside, P. M. (1995). Hydroelectric dams in the Brazilian Amazon as sources of 'greenhouse' gases. Environ. Conserv. 22, 7-19. doi: $10.1017 / \mathrm{S} 0376892900034020$

Fearnside, P. M. (2004). Greenhouse gas emissions from hydroelectric dams: controversies provide a springboard for rethinking a supposedly 'clean' energy source. An editorial comment. Clim. Change 66, 1-8. doi: 10.1023/b:clim.0000043174.02841.23

Feng, X., Feakins, S. J., Liu, Z., Ponton, C., Wang, R. Z., Karkabi, E., et al. (2016). Source to sink: evolution of lignin composition in the Madre de Dios River system with connection to the Amazon basin and offshore. J. Geophy. Res. Biogeosci. 121, 1316-1338. doi: 10.1002/2016JG003323

Feng, X., Simpson, A. J., Wilson, K. P., Williams, D. D., and Simpson, M. J. (2008). Increased cuticular carbon sequestration and lignin oxidation in response to soil warming. Nat. Geosci. 1, 836-839. doi: 10.1038/ngeo361

Fetter, C. W. (1988). Applied hydrogeology. 2nd Edn. New York, NY: Macmillan.

Fichot, C. G., and Benner, R. (2014). The fate of terrigenous dissolved organic carbon in a river-influenced ocean margin. Global Biogeochem. Cycles 28, 300-318. doi: 10.1002/2013GB004670

Fichot, C. G., Lohrenz, S. E., and Benner, R. (2014). Pulsed, cross-shelf export of terrigenous dissolved organic carbon to the Gulf of Mexico. J. Geophys. Res. Oceans. 119, 1176-1194. doi: 10.1002/2013JC009424

Field, C. B., Behrenfeld, M. J., Randerson, J. T., and Falkowski, P. (1998).Primary production of the biosphere: integrating terrestrial and oceanic components. Science. 281, 237-240. doi: 10.1126/science.281.5374.237

Filoso, S., Williams, M. R., and Melack, J. M. (1999). Composition and deposition of throughfall in a flooded forest archipelago. Biogeochemistry 45, 169-195. doi: 10.1007/BF01106780

Foster, S. S. D., and Chilton, P. J. (2003). Groundwater: the processes and global significance of aquifer degradation. Philos. Trans. R. Soc. London B Biol. Sci. 358, 1957-1972. doi: 10.1098/rstb.2003.1380

Galy, V., and Eglinton, T. (2011). Protracted storage of biospheric carbon in the Ganges-Brahmaputra basin. Nat. Geosci. 4, 843-847. doi: 10.1038/ ngeo1293

Galy, V., Peucker-Ehrenbrink, B., and Eglinton, T. (2015). Global carbon export from the terrestrial biosphere controlled by erosion. Nature 521, 204-207. doi: $10.1038 /$ nature 14400

Gattuso, J. P., Frankignoulle, M., and Wollast, R. (1998). Carbon and carbonate metabolism in coastal aquatic ecosystems. Annu. Rev. Ecol. Syst. 29, 405-434 doi: 10.1146/annurev.ecolsys.29.1.405

Gergel, S. E., Turner, M. G., and Kratz, T. K. (1999). Dissolved organic carbon as an indicator of the scale of watershed influence on lakes and rivers. Ecol. Appl. 9, 1377-1390. doi: 10.1890/1051-0761(1999)009[1377:DOCAAI]2.0.CO;2

Germer, S., Neill, C., Krusche, A. V., Gouveia Neto, S. C., and Elsenbeer, H. (2007). Amazonia; nutrient fluxes; rainfall chemistry; sequential sampling; throughfall chemistry; tropical rain forest. Biogeochemistry 86, 155-174. doi: 10.1007/s10533-007-9152-9 
Ghiorse, W. C., and Wilson, J. T. (1988). Microbial ecology of the terrestrial subsurface. Adv. Appl. Microbiol. 33, 107-172. doi: 10.1016/S0065-2164(08)70206-5

Gibbes, B., Robinson, C., Li, L., Lockington, D., and Li, H. (2008). Tidally driven pore water exchange within offshore intertidal sandbanks: part II numerical simulations. Estuar. Coast. Shelf Sci. 80, 472-482. doi: 10.1016/j.ecss.2008.08.0213

Gibert, J., Stanford, J. A., Dole Olivier, M.-J., and Ward, J. V. (1994). "Basic attributes of groundwater ecosystems and prospects for research," in Groundwater Ecology, eds J. Gibert, D. L. Danielopol, and J. A. Stanford (San Diego, CA: Academic Press), 7-40.

Gillooly, J. F., Brown, J. H., West, G. B., Savage, V. M., and Charnov, E. L. (2001). Effects of size and temperature on metabolic rate. Science 293, 2248-2251. doi: $10.1126 /$ science.1061967

Gillooly, J. F., Charnov, E. L., West, G. B., Savage, V. M., and Brown, J. H. (2002). Effects of size and temperature on developmental time. Nature 417, 70-73. doi: $10.1038 / 417070 a$

Goñi, M. A., Ruttenberg, K. C., and Eglinton, T. I. (1997). Sources and contribution of terrigenous organic carbon to surface sediments in the Gulf of Mexico. Nature 389, 275-278.

Goñi, M. A., Ruttenberg, K. C., and Eglinton, T. I. (1998). A reassessment of the sources and importance of land-derived organic matter in surface sediments from the Gulf of Mexico. Geochim. Cosmochim. Acta 62, 3055-3075.

Gonsior, M., Peake, B. M., Cooper, W. T., Podgorski, D., D’Andrilli, J., and Cooper, W. J. (2009). Photochemically induced changes in dissolved organic matter identified by ultrahigh resolution Fourier transform ion cyclotron resonance mass spectrometry. Environ. Sci. Technol. 43, 698-703. doi: 10.1021/es8022804

Gontikaki, E., Thornton, B., Huvenne, V. A., and Witte, U. (2013). Negative priming effect on organic matter mineralisation in NE Atlantic slope sediments. PLoS ONE 8:e67722. doi: 10.1371/journal.pone.0067722

Greenfield, S. M. (1957). Rain scavenging of radioactive particulate matter from the atmosphere. J. Meteorol. 14, 115-125.

Gromaire-Mertz, M. C., Garnaud, S., Gonzalez, A., and Chebbo, G. (1999). Characterisation of urban runoff pollution in Paris. Water Sci. Technol. 39, 1-8. doi: 10.1016/S0273-1223(99)00002-5

Grøn, C., Tørsløv, J., Albrechtsen, H. J., and Jensen, H. M. (1992). Biodegradability of dissolved organic carbon in groundwater from an unconfined aquifer. Sci. Total Environ. 117, 241-251. doi: 10.1016/0048-9697(92)90091-6

Guenet, B., Danger, M., Harrault, L., Allard, B., Jauset-Alcala, M., Bardoux, G., et al. (2014). Fast mineralization of land-born C in inland waters: first experimental evidences of aquatic priming effect. Hydrobiologia.721, 35-44. doi: 10.1007/s10750-013-1635-1

Guerin, F., Abril, G., Richard, S., Burban, B., Reynouard, C., Seyler, P., et al. (2006). Methane and carbon dioxide emissions from tropical reservoirs: significance of downstream rivers. Geophys. Res. Lett. 33, 25-30. doi: 10.1029/2006GL027929

Guo, L., Semiletov, I., Gustafsson, Ö., Ingri, J., Andersson, P., Dudarev, O., et al. (2004). Characterization of Siberian Arctic coastal sediments: implications for terrestrial organic carbon export. Global Biogeochem. Cycles 18, GB1036. doi: 10.1029/2003GB002087

Guo, X., Dai, M., Zhai, W., Cai, W.-J., and Chen, B. (2009). CO $\mathrm{CO}_{2}$ flux and seasonal variability in a large subtropical estuarine system, the Pearl River Estuary, China. J. Geophys. Res. Biogeosci. 114, G03013. doi: 10.1029/2008JG000905

Hallet, B., Hunter, L., and Bogen, J. (1996). Rates of erosion and sediment evacuation by glaciers: a review of field data and their implications. Global Planet Change 12, 213-235. doi: 10.1016/0921-8181(95)00021-6

Hamilton, S. K., Sippel, S. J., and Melack, J. M. (1995). Oxygen depletion and carbon dioxide and methane production in waters of the Pantanal wetland of Brazil, Biogeochemistry 30, 115-141. doi: 10.1007/BF00002727

Hansell, D. A. (2013). Recalcitrant dissolved organic carbon fractions. Annu. Rev. Mar. Sci. 5, 421-445. doi: 10.1146/annurev-marine-120710-100757

Hansell, D. A., Kadko, D., and Bates, N. R. (2004). Degradation of terrigenous dissolved organic carbon in the western Arctic Ocean. Science 304, 858-861. doi: 10.1126/science.1096175

Hedges, J. I. (1992). Global biogeochemical cycles: progress and problems. Mar. Chem. 39, 67-93. doi: 10.1016/0304-4203(92)90096-s

Hedges, J. I., Clark, W. A., Quay, P. D., Richey, J. E., Devol, A. H., and Santos, U. D. M. (1986). Compositions and fluxes of particulate organic material in the Amazon River. Limnol. Oceanogr. 31, 717-738. doi: 10.4319/lo.1986.31.4.0717
Hedges, J. I., and Keil, R. G. (1995). Sedimentary organic-matter preservationAn assessment and speculative synthesis. Mar. Chem. 49, 81-115. doi: 10.1016/0304-4203(95)00008-F

Hedges, J. I., Mayorga, E., Tsamakis, E., McClain, M. E., Aufdenkampe, A., Quay, P., et al. (2000). Organic matter in Bolivian tributaries of the Amazon River: a comparison to the lower mainstream. Limnol. Oceanogr. 45, 1449-1466. doi: 10.4319/lo.2000.45.7.1449

Hedges, J. I., and Keil, R. G. (1995). Sedimentary organic matter preservation: an assessment and speculative synthesis. Mar. Chem. 49, 81-115. doi: 10.1016/0304-4203(95)00008-F

Heffernan, J. B., Soranno, P. A., Angilletta, M. J., Buckley, L. B., Gruner, D. S., Keitt, T. H., et al. (2014). Macrosystems ecology: understanding ecological patterns and processes at continental scales. Front. Ecol. Environ. 12, 5-14. doi: $10.1890 / 130017$

Hernes, P. J., and Benner, R. (2003). Photochemical and microbial degradation of dissolved lignin phenols: implications for the fate of terrigenous dissolved organic matter in marine environments. J. Geophys. Res. 108, 3291. doi: $10.1029 / 2002$ jc001421

Hernes, P. J., Robinson, A. C., and Aufdenkampe, A. K. (2007). Fractionation of lignin during leaching and sorption and implications for organic matter "freshness". Geophys. Res. Lett. 34:L1740. doi: 10.1029/2007GL0 31017

Hernes, P. J., Spencer, R. G., Dyda, R., O'Green, A., and Dahlgren, R. (2017). The genesis and exodus of vascular plant DOM from an oak woodland landscape. Front. Mar. Sci. doi: 10.3389/feart.2017.00009

Hertkorn, N., Benner, R., Frommberger, M., Schmitt-Kopplin, P., Witt, M., Kaiser, K., et al. (2006). Characterization of a major refractory component of marine dissolved organic matter. Geochim. Cosmochim. Acta 70, 2990-3010. doi: 10.1016/j.gca.2006.03.021

Hessen, D. O., Carroll, J., Kjeldstad, B., Korosov, A. A., Pettersson, L. H., Pozdnyakov, D., et al. (2010). Input of organic carbon as determinant of nutrient fluxes, light climate and productivity in the $\mathrm{Ob}$ and Yenisey estuaries. Estuar. Coast. Shelf Sci. 88, 53-62. doi: 10.1016/j.ecss.2010.03.006

Hill, A. R., Kemp, W. A., Buttle, J. M., and Goodyear, D. (1999). Nitrogen chemistry of subsurface storm runoff on forested Canadian Shield hillslopes. Water Resour. Res. 35, 811-821. doi: 10.1029/1998WR900083

Hinojosa, J. L., Moy, C. M., Stirling, C. H., Wilson, G. S., and Eglinton, T. I. (2014). Carbon cycling and burial in New Zealand's fjords. Geochem. Geophys. Geosyst. 15, 4047-4063. doi: 10.1002/2014gc005433

Hinton, M. J., Schiff, S. L., and English, M. C. (1998). Sources and flowpaths of dissolved organic carbon during storms in two forested watersheds of the Precambrian Shield. Biogeochemistry 41, 175-197. doi: 10.1023/A:1005903428956

Holmes, R. M., McClelland, J. W., Raymond, P. A., Frazer, B. B., Peterson, B. J., and Stieglitz, M. (2008). Lability of DOC transported by Alaskan rivers to the Arctic Ocean. Geophys. Res. Lett. 35:L03402. doi: 10.1029/2007GL0 32837

Hood, E., Fellman, J., Spencer, R. G., Hernes, P. J., Edwards, R., D’Amore, D., et al. (2009). Glaciers as a source of ancient and labile organic matter to the marine environment. Nature 462, 1044-1047. doi: 10.1038/nature08580

Hood, E., and Scott, D. (2008). Riverine organic matter and nutrients in southeast Alaska affected by glacial coverage. Nat. Geosci. 1, 583-587. doi: $10.1038 /$ ngeo 280

Horton, R. E. (1933). The role of infiltration in the hydrologic cycle. Trans. Am. Geophys. Union 14, 446-460. doi: 10.1029/TR014i001p00446

Huettel, M., Berg, P., and Kostka, J. E. (2014). Benthic exchange and biogeochemical cycling in permeable sediments. Ann. Rev. Mar. Sci. 6, 23-51. doi: 10.1146/annurev-marine-051413-012706

Huettel, M., and Rusch, A. (2000). Transport and degradation of phytoplankton in permeable sediment. Limnol. Oceanogr. 45, 534-549. doi: $10.4319 /$ lo.2000.45.3.0534

Ibánhez, J. S. P., Diverrès, D., Araujo, M., and Lefèvre, N. (2015). Seasonal and interannual variability of sea-air $\mathrm{CO} 2$ fluxes in the tropical Atlantic affected by the Amazon River plume. Global Biogeochem. Cycles 28, 1-16. doi: 10.1002/2015GB005110

Ivanov, V. V., Shapiro, G. I., Huthnance, J. M., Aleynik, D. L., and Golovin, P. N. (2004). Cascades of dense water around the world ocean. Prog. Oceanogr. 60, 47-98. doi: 10.1016/j.pocean.2003.12.002 
Jacinthe, P. A., Filippelli, G. M., Tedesco, L. P., and Raftis, R. (2012). Carbon storage and greenhouse gases emission from a fluvial reservoir in an agricultural landscape. Catena 94, 53-63. doi: 10.1016/j.catena.2011.03.012

Jiang, L.-Q., Cai, W.-J., and Wang, Y. (2008). A comparative study of carbon dioxide degassing in river- and marine-dominated estuaries. Limnol. Oceanogr. 53, 2603-2615. doi: 10.4319/lo.2008.53.6.2603

Jobbágy, E. G., and Jackson, R. B. (2000). The vertical distribution of soil organic carbon and its relation to climate and vegetation. Ecol. Appl. 10, 423-436. doi: 10.1890/1051-0761(2000)010[0423:TVDOSO]2.0.CO;2

Johnson, K. S., Paull, C. K., Barry, J. P., and Chavez, F. P. (2001). A decadal record of underflows from a coastal river into the deep sea. Geology. 29, 1019-1022. doi: 10.1130/0091-7613(2001)029<1019:ADROUF>2.0.CO;2

Johnson, M. S., Lehmann, J., Riha, S. J., Krusche, A. V., Richey, J. E., Ometto, J. P. H., et al. (2008). $\mathrm{CO}_{2}$ efflux from Amazonian headwater streams represents a significant fate for deep soil respiration. Geophys. Res. Lett. 35:L17401. doi: 10.1029/2008GL034619

Jones, J. B., and Holmes, R. M. (1996). Surface-subsurface interactions in stream ecosystems. Trends Ecol. Evol. 11, 239-242. doi: 10.1016/0169-5347(96)10013-6

Jones, J. B., and Mulholland, P. J. (1998). Methane input and evasion in a hardwood forest stream: effects of subsurface flow from shallow and deep pathways. Limnol. Oceanogr. 43, 1243-1250. doi: 10.4319/lo.1998.43.6.1243

Joshi, I., and D'Sa, E. J. (2015). Seasonal variation of colored dissolved organic matter in barataria bay, louisiana, using combined landsat and field data. Remote Sens. 7, 12478-12502. doi: 10.3390/rs70912478

Judd, K. E., Crump, B. C., and Kling, G. W. (2007). Bacterial responses in activity and community composition to photo-oxidation of dissolved organic matter from soil and surface waters. Aquat. Sci. 69, 96-107. doi: 10.1007/s00027-006-0908-4

Junk, W. J., Bayley, P. B., and Sparks, R. E. (1989). The flood pulse concept in river-floodplain systems. Can. Special Public. Fish. Aquat. Sci. 106, 10-127.

Junk, W. J., and Howard-Williams, C. (1984). "Ecology of aquatic macrophytes in Amazonia," in The Amazon, Limnology and Landscape Ecology of a Mighty Tropical River and its Basin, ed H. Sioli (Dordrecht: Junk). 269-293.

Kaiser, K., Guggenberger, G., and Haumaier, L. (2004). Changes in dissolved ligninderived phenols, neutral sugars, uronic acids, and amino sugars with depth in forested Haplic Arenosols and Rendzic Leptosols. Biogeochemistry 70, 135-151. doi: 10.1023/B:BIOG.0000049340.77963.18

Kalbitz, K., Solinger, S., Park, J. H., Michalzik, B., and Matzner, E. (2000). Controls on the dynamics of dissolved organic matter in soils: a review. Soil Sci. 165, 277-304. doi: 10.1097/00010694-200004000-00001

Kankaala, P., Huotari, J., Peltomaa, E., Saloranta, T., and Ojala, A. (2006). Methanotrophic activity in relation to methane efflux and total heterotrophic bacterial production in a stratified, humic, boreal lake. Limnol. Oceanogr. 51, 1195-1204. doi: 10.4319/lo.2006.51.2.1195

Karlsson, G., Grimvall, A., and Löwgren, M. (1988). River basin perspective on long-term changes in the transport of nitrogen and phosphorus. Water Res. 22, 139-149. doi: 10.1016/0043-1354(88)90072-3

Keil, R. G., and Mayer, L. M. (2014). "Mineral matrices and organic matter," in Treatise on Geochemistry, Vol. 12, 2nd Edn., eds H. Holland and K. Turekian (Amsterdam: Elsevier), 337-359.

Keil, R. G., Mayer, L. M., Quay, P. D., Richey, J. E., and Hedges, J. I. (1997). Loss of organic matter from riverine particles in deltas. Geochim. Cosmochim. Acta 61, 1507-1511. doi: 10.1016/S0016-7037(97)00044-6

Kellerman, A. M., Kothawala, D. N., Dittmar, T., and Tranvik, L. J. (2015). Persistence of dissolved organic matter in lakes related to its molecular characteristics. Nat. Geosci. 8, 454-457. doi: 10.1038/ngeo2440

Kemenes, A., Forsberg, B. R., and Melack, J. M. (2007). Methane release below a tropical hydroelectric dam. Geophys. Res. Lett. 34, L12809. doi: $10.1029 / 2007 \mathrm{gl} 029479$

Kennedy, V. C. (1971). "Silica variation in stream water with time and discharge," in Nonequilibrium systems in natural water chemistry, Vol. 106, ed J. D. Hem (Washington, DC: American Chemical Society Advances in Chemistry), 95-130.

Kerminen, V. M., Virkkula, A., Hillamo, R., Wexler, A. S., and Kulmala, M. (2000). Secondary organics and atmospheric cloud condensation nuclei production. J. Geophys. Res. Atmosph. 105, 9255-9264. doi: 10.1029/1999JD901203

Kineke, G. C., Woolfe, K. J., Kuehl, S. A., Milliman, J. D., Dellapenna, T. M., and Purdon, R. G. (2000). Sediment export from the Sepik River, Papua
New Guinea: evidence for a divergent sediment plume. Cont. Shelf Res. 20, 2239-2266. doi: 10.1016/S0278-4343(00)00069-8

Kirschbaum, M. U. (1995). The temperature dependence of soil organic matter decomposition, and the effect of global warming on soil organic C storage. Soil Biol. Biochem. 27, 753-760. doi: 10.1016/0038-0717(94)00242-S

Kirschke, S., Bousquet, P., Ciais, P., Saunois, M., Canadell, J. G., Dlugokencky, E. J., et al. (2013). Three decades of global methane sources and sinks. Nat. Geosci. 6, 813-823. doi: 10.1038/ngeo1955

Kitidis, V., Stubbins, A. P., Uher, G., Goddard, R. C. U., Law, C. S., and Woodward, E. M. S. (2006). Variability of chromophoric organic matter in surface waters of the Atlantic Ocean. Deep Sea Res. Part II Top. Stud. Oceanogr. 53, 1666-1684. doi: 10.1016/j.dsr2.2006.05.009

Komada, T., Druffel, E. R. M., and Trumbone, S. E. (2004). Oceanic export of relict carbon by small mountainous rivers. Geophys. Res. Lett. 31:L07504. doi: 10.1029/2004GL019512

Kristensen, E., Bouillon, S., Dittmar, T., and Marchand, C. (2008). Organic carbon dynamics in mangrove ecosystems: a review. Aquat. Bot. 89, 201-219. doi: 10.1016/j.aquabot.2007.12.005

Kuivila, K. M., Murray, J. W., Devol, A. H., Lidstrom, M. E., and Reimers, C. E. (1988). Methane cycling in the sediments of Lake Washington. Limnol. Oceanogr. 33, 571-581. doi: 10.4319/lo.1988.33.4.0571

Kundzewicz, Z. W., and Döll, P. (2009). Will groundwater ease freshwater stress under climate change? Hydrol. Sci. J. 54, 665-675. doi: 10.1623/hysj.54.4.665

Kundzewicz, Z. W., Mata, L. J., Arnell, N. W., Döll, P., Jimenez, B., Miller, K., et al. (2008). The implications of projected climate change for freshwater resources and their management. Hydrol. Sci. J. 53, 3-10. doi: 10.1623/hysj.53.1.3

Kuzyakov, Y., Friedel, J. K., and Stahr, K. (2000). Review of mechanisms and quantification of priming effects. Soil Biol. Biochem. 32, 1485-1498. doi: 10.1016/S0038-0717(00)00084-5

Lauerwald, R., Laruelle, G. G., Hartmann, J., Ciais, P., and Regnier, P. A. (2015). Spatial patterns in $\mathrm{CO}_{2}$ evasion from the global river network. Global Biogeochem. Cycles 29, 534-554. doi: 10.1002/2014GB004941

Lechtenfeld, O. J., Hertkorn, N., Shen, Y., Witt, M., and Benner, R. (2015). Marine sequestration of carbon in bacterial metabolites. Nat. Commun. 6, 6711. doi: $10.1038 /$ ncomms7711

Lehmann, J., and Kleber, M. (2015). The contentious nature of soil organic matter. Nature 528, 60-68. doi: 10.1038/nature16069

Leithold, E., Blair, N. E., and Perkey, D. W. (2006). Geomorphologic controls on the age of particulate organic carbon from small mountainous and upland rivers. Global Biogeochem. Cycles 20:GB3022. doi: 10.1029/2005GB002677

Levia, D. F., and Frost, E. E. (2003). A review and evaluation of stemflow literature in the hydrologic and biogeochemical cycles of forested and agricultural ecosystems. J. Hydrol. 274, 1-29. doi: 10.1016/S0022-1694(02)00399-2

Le Quéré, C., Moriarty, R., Andrew, R. M., Peters, G. P., Ciais, P., Friedlingstein, P., et al. (2015). Global carbon budget 2014. Earth Syst. Sci. Data 7, 47-85. doi: 10.5194/essd-7-47-2015

Letscher, R., Hansell, D. A., and Kadko, D. (2011). Rapid removal of terrigenous dissolved organic carbon over the Eurasian shelves of the Arctic Ocean. Mar. Chem. 123, 78-87. doi: 10.1016/j.marchem.2010.10.002

Li, H. J., Yan, J. X., Yue, X. F., and Wang, M. B. (2008). Significance of soil temperature and moisture for soil respiration in a Chinese mountain area. Agric. Forest Meteorol. 148, 490-503. doi: 10.1016/j.agrformet.2007.10.009

Liikanen, A., Huttunen, J. T., Valli, K., and Martikainen, P. J. (2002). Methane cycling in the sediment and water column of mid-boreal hyper-eutrophic Lake Kevaton. Finland Arch. Hydrobiol. 154, 585-603. doi: 10.1127/archiv-hydrobiol/154/2002/585

Linsley, J.r., R. K., and Kohler, M. A., Paulhus, J.L.H. (1975). Hydrology for Engineers. New York, NY: McGraw-Hill Book Co., Inc.

Löhnis, F. (1926). Nitrogen availability of green manures. Soil Sci. 22.4, 253-290. doi: 10.1097/00010694-192610000-00001

Lohrenz, S. E., Fahnenstiel, G. L., Redalje, D. G., Lang, G. A., Dagg, M. J., Whitledge, T. E., et al. (1999). Nutrients, irradiance, and mixing as factors regulating primary production in coastal waters impacted by the Mississippi River plume. Cont. Shelf Res. 19, 1113-1141. doi: 10.1016/S0278-4343(99)00012-6

López-Urrutia, Á., San Martin, E., Harris, R. P., and Irigoien, X. (2006). Scaling the metabolic balance of the oceans. Proc. Natl. Acad. Sci. U.S.A. 103, 8739-8744. doi: $10.1073 /$ pnas. 0601137103 
Lotze, H. K. (2010). "Historical reconstruction of human-induced changes in U.S. estuaries," in Oceanography and Marine Biology: An Annual Review, Vol. 48, eds R. N. Gibson, R. J. A. Atkinson and J. D. M. Gordon (Boca Raton, FL: CRC), 267-338.

Lotze, H. K., Lenihan, H. S., Bourque, B. J., Bradbury, R. H., Cooke, R. G., Kay, M. C., et al. (2006). Depletion, degradation, and recovery potential of estuaries and coastal seas. Science 312, 1806-1809. doi: 10.1126/science.1128035

Lubchenco, J., and Petes, L. E. (2010). The interconnected biosphere: science at the ocean's tipping points. Oceanography 23, 115-29. doi: 10.5670/oceanog.2010.55

Mackenzie, F. T., and Lerman, A. (2006). Carbon in the Geobiosphere: Earth's Outer Shell. Berlin: Springer Science \& Business Media.

Mackenzie, F. T., Lerman, A., and Andersson, A. J. (2004). Past and present of sediment and carbon biogeochemical cycling models. Biogeosci. Discuss. 1, 27-85. doi: 10.5194/bgd-1-27-2004

Maeck, A., DelSontro, T., McGinnis, D. F., Fischer, H., Flury, S., Schmidt, M., et al. (2013). Sediment trapping by dams creates methane emission hot spots. Environ. Sci. Technol. 47, 8130-8137. doi: 10.1021/es4003907

Mann, P. J., Eglinton, T. I., McIntyre, C. P., Zimov, N., Davydova, A., Vonk, J. E., et al. (2015). Utilization of ancient permafrost carbon in headwaters of Arctic fluvial networks. Nat. Commun. 6, 7856. doi: 10.1038/ncomms8856

Mann, P. J., Spencer, R. G., Dinga, B. J., Poulsen, J. R., Hernes, P. J., Fiske, G., et al. (2014). The biogeochemistry of carbon across a gradient of streams and rivers within the Congo Basin. J. Geophy. Res. Biogeosc. 119, 687-702. doi: $10.1002 / 2013 j g 002442$

Markewitz, D., Davidson, E., Moutinho, P., and Nepstad, D. (2004). Nutrient loss and redistribution after forest clearing on highly weathered soil in Amazonia. Ecol. Appl. 14, 177-199. doi: 10.1890/01-6016

Martens, D., Reedy, T., and Lewis, D. (2004). Soil organic carbon content and composition of 130-year crop, pasture and forest land-use managements. Global Change Biol. 10, 65-78. doi: 10.1046/j.1529-8817.2003.00722.x

Martin, E. E., Ingalls, A. E., Richey, J. E., Keil, R. G., Santos, G. M., Truxal, L. T., et al. (2013). Age of riverine carbon suggests rapid export of terrestrial primary production in tropics. Geophys. Res. Lett. 40, 5687-5691. doi: 10.1002/2013GL057450

Matthews, E. (1997). Global litter production, pools, and turnover times: estimates from measurement data and regression models. J. Geophys. Res. 102, 18771-18800. doi: 10.1029/97JD02956

Mayorga, E., Aufdenkampe, A. K., Masiello, C. A., Krusche, A. V., Hedges, J. I., Quay, P. D., et al. (2005). Young organic matter as a source of carbon dioxide outgassing from Amazonian rivers. Nature 436, 538-541. doi: $10.1038 /$ nature 03880

McCallister, S. L., Bauer, J. E., Cherrier, J. E., and Ducklow, H. W. (2004). Assessing sources and ages of organic matter supporting river and estuarine bacterial production: a multiple-isotope $(\triangle 14 \mathrm{C}, \delta 13 \mathrm{C}$, and $\delta 15 \mathrm{~N})$ approach. Limnol. Oceanogr. 49, 1687-1702. doi: 10.4319/lo.2004.49.5.1687

McCluney, K. E., Poff, N. L., Palmer, M. A., Thorp, J. H., Poole, G. C., Williams, B. S., et al. (2014). Riverine macrosystems ecology: sensitivity, resistance, and resilience of whole river basins with human alterations. Front. Ecol. Environ. 12, 48-58. doi: 10.1890/120367

McKee, B. (2003). RiOMar: The Transport, Transformation and Fate of Carbon in River-Dominated Ocean Margins. Report of the RiOMarWorkshop, 1-3 November 2001. Tulane University, New Orleans, LA.

McKee, B. A., Aller, R. C., Allison, M. A., Bianchi, T. S., and Kineke, G. C. (2004). Transport and transformation of dissolved and particulate materials on continental margins influenced by major rivers: benthic boundary layer and seabed processes. Cont. Shelf Res. 24, 899-926. doi: 10.1016/j.csr.2004.02.009

Medeiros, P. M., Fernandes, M. F., Dick, R. P., and Simoneit, B. R. T. (2006). Seasonal variations in sugar contents and microbial community in a ryegrass soil. Chemosphere 65, 832-839. doi: 10.1016/j.chemosphere.2006.03.025

Medeiros, P. M., Seidel, M., Dittmar, T., Whitman, W. B., and Moran, M. A. (2015b). Drought-induced variability in dissolved organic matter composition in a marsh-dominated estuary. Geophys. Res. Lett. 42, 6446-6453. doi: 10.1002/2015GL064653

Medeiros, P. M., Seidel, M., Niggemann, J., Spencer, R. G. M., Hernes, P. J., Yager, P. L., et al. (2016). A novel molecular approach for tracing terrigenous dissolved organic matter into the deep ocean. Global Biogeochem. Cycles 30, 689-699. doi: 10.1002/2015GB005320
Medeiros, P. M., Seidel, M., Ward, N. D., Carpenter, E. J., do Rosário Gomes, H., Niggemann, J., et al. (2015a). Fate of Amazon River dissolved organic matter in the Tropical Atlantic Ocean. Global Biogeochem. Cycles 29, 677-690. doi: 10.1002/2015GB005115

Medeiros, P. M., Sikes, E. L., Thomas, B., and Freeman, K. H. (2012). Flow discharge influences on input and transport of particulate and sedimentary organic carbon along a small temperate river. Geochim. Cosmochim. Acta 77, 317-334. doi: 10.1016/j.gca.2011.11.020

Medeiros, P. M., and Simoneit, B. R. T. (2008). Multi-biomarker characterization of sedimentary organic carbon in small rivers draining the northwestern United States. Org. Geochem. 39, 52-74. doi: 10.1016/j.orggeochem.2007.10.001

Melack, J. M., and Forsberg, B. R. (2001). "Biogeochemistry of Amazon floodplain lakes and associated wetlands," in The Biogeochemistry of the Amazon Basin, eds M. E. McClain, R. L. Victoria, J. E. Richey (New York, NY: Oxford University. Press), 235-274.

Mendonça, R., Kosten, S., Sobek, S., Barros, N., Cole, J. J., Tranvik, L., et al. (2012). Hydroelectric carbon sequestration. Nat. Geosci. 5, 838-840. doi: 10.1038/ngeo1653

Mendonça, R., Kosten, S., Sobek, S., Cole, J. J., Bastos, A. C., Albuquerque, A. L., et al. (2014). Carbon sequestration in a large hydroelectric reservoir: an integrative seismic approach. Ecosystems 17, 430-441. doi: 10.1007/s10021-013-9735-3

Meybeck, M. (1982). Carbon, nitrogen, and phosphorus transport by world rivers. Am. J. Sci. 282, 401-450. doi: 10.2475/ajs.282.4.401

Michels, K. H., Suckow, A., Breitzke, M., Kudrass, H. R., and Kottke, B. (2003). Sediment transport in the shelf canyon "Swatch of No Ground"(Bay of Bengal). Deep Sea Res. Part II Top. Stud. Oceanogr. 50, 1003-1022. doi: 10.1016/S0967-0645(02)00617-3

Milliman, J. D., and Syvitski, J. P. M. (1992). Geomorphic/tectonic control of sediment transport to the ocean: the importance of small mountainous rivers. J. Geol. 100, 525-544. doi: 10.1086/629606

Minshall, G. W., Cummins, K. W., Petersen, R. C., Cushing, C. E., Bruns, D. A., Sedell, J. R., et al. (1985). Developments in stream ecosystem theory. Can. J. Fish. Aquat. Sci. 42, 1045-1055. doi: 10.1139/f85-130

Mitsch, W. J., Day, J. W., Zhang, L., and Lane, R. R. (2005). Nitrate-nitrogen retention in wetlands in the Mississippi River Basin. Ecol. Eng. 24, 267-278. doi: 10.1016/j.ecoleng.2005.02.005

Molinas, E., Vinzon, S. B., Vilela, C. D. P. X., and Gallo, M. N. (2014). Structure and position of the bottom salinity front in the Amazon Estuary. Ocean Dyn. 64, 1583-1599. doi: 10.1007/s10236-014-0763-0

Monteith, D. T., Stoddard, J. L., Evans, C. D., de Wit, H. A., Forsius, M., Høgåsen, T., et al. (2007). Dissolved organic carbon trends resulting from changes in atmospheric deposition chemistry. Nature 450, 537-540. doi: $10.1038 /$ nature 06316

Moore, W. S. (2010). The effect of submarine groundwater discharge on the ocean. Annu. Rev. Mar. Sci. 2, 59-88. doi: 10.1146/annurev-marine-120308-081019

Moore, W. S., Beck, M., Riedel, T., Rutgers van der Loeff, M., Dellwig, O., Shaw, T. J., et al. (2011). Radium-based pore water fluxes of silica, alkalinity, manganese, DOC, and uranium: a decade of studies in the German Wadden Sea. Geochim. Cosmochim. Acta 75, 6535-6555. doi: 10.1016/j.gca.2011.08.037

Moore, W. S., Sarmiento, J. L., and Key, R. M. (2008). Submarine groundwater discharge revealed by 228Ra distribution in the upper Atlantic Ocean. Nat. Geosci. 1, 309-311. doi: 10.1038/ngeo183

Mopper, K., Kieber, D. J., and Stubbins, A. (2015). "Marine photochemistry of organic matter: processes and impacts," in Biogeochemistry of Marine Dissolved Organic Matter, Vol. 2, eds D. Hansell and C. Carlson (San Diego, CA: Academic Press), 389-450.

Moran, M. A., Kujawinski, E. B., Stubbins, A., Fatland, R., Aluwihare, L. I., Buchan, A., et al. (2016). Deciphering ocean carbon in a changing world. Proc. Natl. Acad. Sci. U.S.A. 113, 3143-3151. doi: 10.1073/pnas.1514645113

Moran, M. A., Pomeroy, L. R., Sheppard, E. S., Atkinson, L. P., and Hodson, R. E. (1991). Distribution of terrestrially derived dissolved organic matter on the southeastern U.S. continental shelf. Limnol. Oceanogr. 36, 1134-1149. doi: 10.4319/lo.1991.36.6.1134

Moran, M. A., Sheldon, W. M., and Sheldon, J. E. (1999). Biodegradation of riverine dissolved organic carbon in five estuaries of the southeastern United States. Estuaries 22, 55-64. doi: 10.2307/1352927 
Mulholland, P. J., and Elwood, J. W. (1982). The role of lake and reservoir sediments as sinks in the perturbed global carbon cycle. Tellus 34, 490-499. doi: 10.3402/tellusa.v34i5.10834

Mullenbach, B. L., and Nittrouer, C. A. (2006). Decadal record of sediment export to the deep sea via Eel Canyon. Cont. Shelf Res. 26, 2157-2177. doi: 10.1016/j.csr.2006.07.019

Myers-Pigg, A. N., Louchouarn, P., Amon, R. M., Prokushkin, A., Pierce, K., and Rubtsov, A. (2015). Labile pyrogenic dissolved organic carbon in major Siberian Arctic rivers: implications for wildfire-stream metabolic linkages. Geophys. Res. Lett. 42, 377-385. doi: 10.1002/2014GL062762

Myers-Pigg, A. N., Griffin, R. J., Louchouarn, P., Norwood, M. J., Sterne, A., and Karakurt Cevik, B. (2016). Signatures of biomass burning aerosols in the plume of a saltmarsh wildfire in South Texas. Environ. Sci. Technol. 50, 9308-9314. doi: 10.1021/acs.est.6b02132

Nellemann, C., Corcoran, E., Duarte, C. M., Valdés, L., De Young, C., Fonseca, L., et al. (2009). Blue Carbon: the Role of Healthy Oceans in Binding Carbon: a Rapid Response Assessment. Arendal: United Nations Environment Programme, GRID-Arendal.

Neu, V., Ward, N. D., Krusche, A. V., and Neill, C. (2016). Dissolved organic and inorganic carbon flow paths in an Amazonian transitional forest. Front. Mar. Sci. 3:114. doi: 10.3389/fmars.2016.00114

Newbold, J. D., Mulholland, P. J., Elwood, J. W., and O’Neill, R. V. (1982). Organic carbon spiralling in stream ecosystems. Oikos 38, 266-272. doi: $10.2307 / 3544663$

Nuwer, J. M., and Keil, R. G. (2005). Sedimentary organic matter geochemistry of Clayoquot Sound, Vancouver Island, British Columbia. Limnol. Oceanogr. 50, 1119-1128. doi: 10.4319/lo.2005.50.4.1119

O'Connor, M. I., Piehler, M. F., Leech, D. M., Anton, A., and Bruno, J. F. (2009). Warming and resource availability shift food web structure and metabolism. PLoS Biol. 7:e1000178. doi: 10.1371/annotation/73c277f8-421a4843-9171-403be1a014c7

Odum, W. E., Fisher, J. S., and Pickral, J. C. (1979). "Factors controlling the flux of particulate organic carbon from estuarine wetlands," in Ecological Processes in Coastal and Marine Systems, ed R. J. Livingston (New York, NY: Springer). 69-80.

Opsahl, S., and Benner, R. (1997). Distribution and cycling of terrigenous dissolved organic matter in the ocean. Nature 386, 480-482. doi: 10.1038/386480a0

Orth, R. J., and Moore, K. A. (1983). Chesapeake Bay: an unprecedented decline in submerged aquatic vegetation. Science 222, 51-53. doi: $10.1126 /$ science.222.4619.51

Osterholz, H., Niggemann, J., Giebel, H.-A., Simon, M., and Dittmar, T. (2015). Inefficient microbial production of refractory dissolved organic matter in the ocean. Nat. Commun. 6:7422. doi: 10.1038/ncomms8422

Pabich, W. J., Valiela, I., and Hemond, H. F. (2001). Relationship between DOC concentration and vadose zone thickness and depth below water table in groundwater of Cape Cod, USA. Biogeochemistry 55, 247-268. doi: 10.1023/A:1011842918260

Peter, S., Shen, Y., Kaiser, K., Benner, R., and Durisch-Kaiser, E. (2012b). Bioavailability and diagenetic state of dissolved organic matter in riparian groundwater. J. Geophy. Res. Biogeosc. 117:G04006. doi: 10.1029/2012JG002072

Peter, S., Koetzsch, S., Traber, J., Bernasconi, S. M., Wehrli, B., and Durisch-Kaiser, E. (2012a). Intensified organic carbon dynamics in the groundwater of a restored riparian zone, Freshwater Biol. 57, 1603-1616. doi: 10.1111/j.1365-2427.2012.02821.x

Petsch, S., Eglinton, T., and Edwards, K. (2001). 14C-dead living biomass: evidence for microbial assimilation of ancient organic carbon during shale weathering. Science 292, 1127-1131. doi: 10.1126/science.1058332

Philip, G. T., and Townsend, A. R. (2010). Stoichiometric control of organic carbon-nitrate relationships from soils to the sea. Nature 464, 1178-1181. doi: 10.1038/nature08985

Pio, C. A., Alves, C. A., and Duarte, A. C. (2001). Identification, abundance and origin of atmospheric organic particulate matter in a Portuguese rural area. Atmos. Environ. 35, 1365-1375. doi: 10.1016/S1352-2310(00)00391-5

Porcal, P., Dillon, P. J., and Molot, L. A. (2015). Temperature dependence of photodegradation of dissolved organic matter to dissolved inorganic carbon and particulate organic carbon. PLoS ONE 10:e128884. doi: 10.1371/journal.pone.0128884
Puig, P., and Palanques, A. (1998). Temporal variability and composition of settling particle fluxes on the Barcelona continental margin (Northwestern Mediterranean). J. Mar. Res. 56, 639-654. doi: 10.1357/002224098765 213612

Qualls, R. G., and Haines, B. L. (1992). Biodegradability of dissolved organic matter in forest throughfall, soil solution, and stream water. Soil Sci. Soc. Am. J. 56, 578-586. doi: 10.2136/sssaj1992.03615995005600020038x

Rabalais, N. N., Turner, R. E., Diaz, R. J., and Justic, D. (2009). Global change and eutrophication of coastal waters. ICES J. Mar. Sci. 66, 1528-1537. doi: 10.1093/icesjms/fsp047

Rabotyagov, S. S., Campbell, T. D., White, M., Arnold, J. G., Atwood, J., Norfleet, M. L., et al. (2014). Cost-effective targeting of conservation investments to reduce the northern Gulf of Mexico hypoxic zone. Proc. Natl. Acad. Sci. U.S.A. 111, 18530-18535. doi: 10.1073/pnas.1405837111

Raghukumar, C., Vipparty, V., David, J., and Chandramohan, D. (2001). Degradation of crude oil by marine cyanobacteria. Appl. Microbiol. Biotechnol. 57, 433-436. doi: 10.1007/s002530100784

Raich, J. W., and Potter, C. S. (1995). Global patterns of carbon dioxide emissions from soils. Global Biogeochem. Cycles 9, 23-36. doi: 10.1029/94GB 02723

Raich, J. W., and Schlesinger, W. H. (1992). The global carbon dioxide flux in soil respiration and its relationship to vegetation and climate. Tellus 44B, 81-99. doi: 10.3402/tellusb.v44i2.15428

Rasera, F. L. M. D. F., Krusche, A. V., Richey, J. E., Ballester, M. V., and Victória, R. L. (2013). Spatial and temporal variability of $\mathrm{pCO}_{2}$ and $\mathrm{CO}_{2}$ efflux in seven Amazonian Rivers. Biogeochemistry 116, 241-259. doi: 10.1007/s10533-013-9854-0

Raymond, P. A., and Bauer, J. E. (2000). Bacterial consumption of DOC during transport through a temperate estuary. Aquat. Microb. Ecol. 22, 1-12. doi: 10.3354/ame022001

Raymond, P. A., and Bauer, J. E. (2001). Riverine export of aged terrestrial organic matter to the North Atlantic Ocean. Nature 409, 497-500. doi: $10.1038 / 35054034$

Raymond, P. A., Bauer, J. E., Caraco, N. F., Cole, J. J., Longworth, B., and Petsch, S. T. (2004). Controls on the variability of organic matter and dissolved inorganic carbon ages in northeast US rivers. Mar. Chem. 92, 353-366. doi: 10.1016/j.marchem.2004.06.036

Raymond, P. A., Caraco, N. F., and Cole, J. J. (1997). Carbon dioxide concentration and atmospheric flux in the Hudson River. Estuaries 20, 381-390. doi: 10.2307/1352351

Raymond, P. A., Hartmann, J., Lauerwald, R., Sobek, S., McDonald, C., Hoover, M., et al. (2013). Global carbon dioxide emissions from inland waters. Nature 503, 355-359. doi: 10.1038/nature 12760

Raymond, P. A., and Saiers, J. E. (2010). Event controlled DOC export from forested watersheds. Biogeochemistry 100, 197-209. doi: 10.1007/s10533-010-9416-7

Raymond, P. A., Saiers, J. E., and Sobczak, W. V. (2016). Hydrological and biogeochemical controls on watershed dissolved organic matter transport: pulse-shunt concept. Ecology 97, 5-16. doi: 10.1890/14-1684.1

Redalje, D. G., and Fahnenstiel, G. L. (1994). The relationship between primary production and the vertical export of particulate organic matter in a riverimpacted coastal ecosystem. Estuaries 17, 829-838. doi: 10.2307/1352751

Regnier, P., Friedlingstein, P., Ciais, P., Mackenzie, F. T., Gruber, N., Janssens, I. A., et al. (2013). Anthropogenic perturbation of the carbon fluxes from land to ocean. Nat. Geosci. 6, 597-607. doi: 10.1038/ngeo1830

Richey, J. E., Melack, J. M., Aufdenkampe, A. K., Ballester, V. M., and Hess, L. L. (2002). Carbon dioxide evasion from central Amazonian wetlands as a significant source of atmospheric $\mathrm{CO}_{2}$ in the tropics. Nature 416, 617-620. doi: $10.1038 / 416617 \mathrm{a}$

Riipinen, I., Pierce, J. R., Yli-Juuti, T., Nieminen, T., Hakkinen, S., Ehn, M., et al. (2011). Organic condensation: a vital link connecting aerosol formation to cloud condensation nuclei (CCN) concentrations. Atmosph. Chem. Phys. 11, 3865. doi: 10.5194/acp-11-3865-2011

Robador, A., Brüchert, V., Steen, A. D., and Arnosti, C. (2010). Temperature induced decoupling of enzymatic hydrolysis and carbon remineralization in long-term incubations of Arctic and temperate sediments. Geochim. Cosmochim. Acta 74, 2316-2326. doi: 10.1016/j.gca.2010.01.022 
Rocha, C. (2008). Sandy sediments as active biogeochemical reactors: compound cycling in the fast lane. Aquat. Microb. Ecol. 53, 119-127. doi: 10.1002/2014GB004941

Rodríguez-Zuniga, U. F., Milori, D. M. B. P., Da Silva, W. T. L., Martin-Neto, L., Oliveira, L. C., and Rocha, J. C. (2008). Changes in optical properties caused by UV-irradiation of aquatic humic substances from the Amazon River basin: seasonal variability evaluation. Environ. Sci. Technol. 42, 1948-1953. doi: $10.1021 /$ es702156n

Røy, H., Lee, J. S., Jansen, S., and de Beer, D. (2008). Tide-driven deep pore-water flow in intertidal sand flats. Limnol. Oceanogr. 53, 1521-1530. doi: $10.4319 /$ lo.2008.53.4.1521

Rusch, A., and Huettel, M. (2000). Advective particle transport into permeable sediments-evidence from experiments in an intertidal sandflat. Limnol. Oceanogr. 45, 525-533. doi: 10.4319/lo.2000.45.3.0525

Sampere, T. P., Bianchi, T. S., Allison, M. A., and McKee, B. A. (2011). Burial and degradation of organic carbon in Louisiana shelf/slope sediments. Estuar. Coast. Shelf Sci. 95, 232-244. doi: 10.1016/j.ecss.2011. 09.003

Sanderman, J., Lohse, K. A., Baldock, J. A., and Amundson, R. (2009). Linking soils and streams: sources and chemistry of dissolved organic matter in a small coastal watershed. Water Resour. Res. 45:W03418. doi: 10.1029/2008WR 006977

Šantl-Temkiv, T., Finster, K., Dittmar, T., Hansen, B. M., Thyrhaug, R., Nielsen, N. W., et al. (2013). Hailstones: a window into the microbial and chemical inventory of a storm cloud. PLoS ONE 8:e53550. doi: 10.1371/journal.pone.0053550

Santos, I. R., Burnett, W. C., Dittmar, T., Suryaputra, I. G. N. A., and Chanton, J. (2009). Tidal pumping drives nutrient and dissolved organic matter dynamics in a Gulf of Mexico subterranean estuary. Geochim. Cosmochim. Acta 73, 1325-1339. doi: 10.1016/j.gca.2008.11.029

Satinsky, B. M., Fortunato, C. S., Doherty, M., Smith, C. B., Sharma, S., Richey, J. E., et al. (2015). Metagenomic and metatranscriptomic inventories of the Amazon River, May 2011. Microbiome 3, 39. doi: 10.1186/s40168-015-0099-0

Sawakuchi, H. O., Bastviken, D., Sawakuchi, A. O., Ward, N. D., Borges, C., Tsai, S. M., et al. (2016). Oxidative mitigation of methane evasion in large Amazonian rivers. Global Chang Biol. 22, 1075-1085. doi: 10.1111/gcb.13169

Schiff, S., Aravena, R., Mewhinney, E., Elgood, R., Warner, B., Dillon, P., et al. (1998). Precambrian shield wetlands: hydrologic control of the sources and export of dissolved organic matter. Clim. Change 40, 167-188. doi: 10.1023/A:1005496331593

Schlesinger, W. H., and Andrews, J. A. (2000). Soil respiration and the global carbon cycle. Biogeochemistry 48, 7-20. doi: 10.1023/A:1006247623877

Schmidt, M. W., Torn, M. S., Abiven, S., Dittmar, T., Guggenberger, G., Janssens, I. A., et al. (2011). Persistence of soil organic matter as an ecosystem property. Nature 478, 49-56. doi: 10.1038/nature10386

Schramm, H. L., Cox, M. S., Tietjen, T. E., and Ezell, A. W. (2009). Nutrient dynamics in the lower Mississippi River floodplain: comparing present and historic hydrologic conditions. Wetlands 29, 476-487. doi: 10.1672/08-62.1

Sedell, J. R., Richey, J. E., and Swanson, F. J. (1989). "The river continuum concept: a basis for the expected ecosystem behavior of very large rivers," in Proceedings of the International Large River Symposium. Canadian Special Publication of Fisheries and Aquatic Sciences (Ontario), 106, 49-55.

Seeboonruang, U. (2012). A statistical assessment of the impact of land uses on surface water quality indexes. J. Environ. Manage. 101, 134-142. doi: 10.1016/j.jenvman.2011.10.019

Seidel, M., Beck, M., Riedel, T., Waska, H., Suryaputra, I. G. N. A., Schnetger, B., et al. (2014). Biogeochemistry of dissolved organic matter in an anoxic intertidal creek bank. Geochim. Cosmochim. Acta 140, 418-434. doi: 10.1016/j.gca.2014.05.038

Seidel, M., Beck, M., Riedel, T., Waska, H., Suryaputra, I. G. N. A., Schnetger, B., et al. (2015b). Benthic-pelagic coupling of nutrients and dissolved organic matter composition in an intertidal sandy beach. Mar. Chem. 176, 150-163. doi: 10.1016/j.marchem.2015.08.011

Seidel, M., Yager, P. L., Ward, N. D., Carpenter, E. J., Gomes, H. R., Krusche, A. V., et al. (2015a). Molecular level transformations of dissolved organic matter in the river to ocean continuum of the Amazon. Mar. Chem. 177, 218-231. doi: 10.1016/j.marchem.2015.06.019
Shanmugam, G., Moiola, R. J., and Damuth, J. E. (1985). "Eustatic control of submarine fan development," in Submarine Fans and Related Turbidite Systems, eds A.H. Bouma, W.R. Normak and N. E. Barnes (New York, NY: Springer), 23-28.

Shapiro, G. I., Huthnance, J. M., and Ivanov, V. V. (2003). Dense water cascading off the continental shelf. J. Geophys. Res. 108:3390. doi: 10.1029/2002JC001610

Shen, Y., Chapelle, F. H., Strom, E. W., and Benner, R. (2015). Origins and bioavailability of dissolved organic matter in groundwater. Biogeochemistry 122, 61-78. doi: 10.1007/s10533-014-0029-4

Sholkovitz, E. R. (1978). The flocculation of dissolved $\mathrm{Fe}, \mathrm{Mn}, \mathrm{Al}, \mathrm{Cu}, \mathrm{Ni}$, Co and Cd during estuarine mixing, Earth Planet. Sci. Lett. 41, 77-86. doi: 10.1016/0012-821X(78)90043-2

Showers, W. J., and Angle, D. G. (1986). Stable isotopic characterization of organic carbon accumulation on the Amazon continental shelf. Cont. Shelf Res. 6, 227-244. doi: 10.1016/0278-4343(86)90062-2

Shuster, W. D., Bonta, J., Thurston, H., Warnemuende, E., and Smith, D. R. (2005). Impacts of impervious surface on watershed hydrology: a review. Urban Water J. 2, 263-275. doi: 10.1080/15730620500386529

Silvertown, J. (2009). A new dawn for citizen science. Trends Ecol. Evol. 24, 467-471. doi: 10.1016/j.tree.2009.03.017

Simoneit, B. R., and Elias, V. O. (2000). Organic tracers from biomass burning in atmospheric particulate matter over the ocean. Mar. Chem. 69, 301-312. doi: 10.1016/S0304-4203(00)00008-6

Singh, A., Jakubowski, A. R., Chidister, I., and Townsend, P. A. (2013). A MODIS approach to predicting stream water quality in Wisconsin. Remote Sens. Environ. 128, 74-86. doi: 10.1016/j.rse.2012.10.001

Sleighter, R. L., and Hatcher, P. G. (2008). Molecular characterization of dissolved organic matter (DOM) along a river to ocean transect of the lower Chesapeake Bay by ultrahigh resolution electrospray ionization Fourier transform ion cyclotron resonance mass spectrometry. Mar. Chem. 110, 140-152. doi: 10.1016/j.marchem.2008.04.008

Slomp, C. P., and Van Cappellen, P. (2004). Nutrient inputs to the coastal ocean through submarine groundwater discharge: controls and potential impact. J. Hydrol. 295, 64-86. doi: 10.1016/j.jhydrol.2004.02.018

Smith, R. W., Bianchi, T. S., Allison, M., Savage, C., and Galy, V. (2015). High rates of organic carbon burial in fjord sediments globally. Nat. Geosci. 8, 450-453. doi: $10.1038 /$ ngeo 2421

Smith, S. V., and Hollibaugh, J. T. (1993). Coastal metabolism and the oceanic organic-carbon balance. Rev. Geophys. 31, 75-89. doi: 10.1029/92rg 02584

Smittenberg, R. H., Hopmans, E. C., Schouten, S., Hayes, J. M., Eglinton, T. I., and Sin-ninghe Damste, J. S. (2004). Compound-specific radiocarbon dating of the varved Holocene sedimentary record of Saanich Inlet, Canada. Paleoceanography 19:PA2012. doi: 10.1029/2003PA000927

Snyder, D. C., Rutter, A. P., Collins, R., Worley, C., and Schauer, J. J. (2009). Insights into the origin of water soluble organic carbon in atmospheric fine particulate matter. Aerosol Sci. Technol. 43, 1099-1107. doi: 10.1080/02786820903188701

Spencer, R. G., Mann, P. J., Dittmar, T., Eglinton, T. I., McIntyre, C., Holmes, R. M., et al. (2015). Detecting the signature of permafrost thaw in Arctic rivers. Geophys. Res. Lett. 42, 2830-2835. doi: 10.1002/2015GL0 63498

Spencer, R. G. M., Stubbins, A., Hernes, P. J., Baker, A., Mopper, K., Aufdenkampe, A. K., et al. (2009). Photochemical degradation of dissolved organic matter and dissolved lignin phenols from the Congo River. J. Geophys. Res. 114:G03010. doi: 10.1029/2009jg000968

Spitzy, A., and Leenheer, J. (1991). "Dissolved organic carbon in rivers," in Biogeochemistry of Major World Rivers, eds E. T. Degens, S. Kempe and J. E. Richey (Chichester: Wiley \& Sons, SCOPE), 43, 213-232.

St Louis, V. L., Kelly, C. A., Duchemin, É., Rudd, J. W. M., and Rosenberg, D. M. (2000). Resevior surfaces as sources of greenhouse gases to the atmosphere: A global estimate. Bioscience 50, 766-775. doi: 10.1641/00063568(2000)050[0766:RSASOG]2.0.CO;2

Stanley, E. H., Casson, N. J., Christel, S. T., Crawford, J. T., Loken, L. C., and Oliver, S. K. (2016). The ecology of methane in streams and rivers: patterns, controls, and global significance. Ecol. Monogr. 86, 146-171. doi: 10.1890/ $15-1027$ 
Steen, A. D., Quigley, L. N., and Buchan, A. (2015). Evidence for the priming effect in a planktonic estuarine microbial community. Front. Mar. Sci. 3:6. doi: $10.3389 /$ fmars.2016.00006

Stow, D. A., Howell, D. G., and Nelson, C. H. (1985). "Sedimentary, tectonic, and sea-level controls," in Submarine Fans and Related Turbidite Systems, eds A. H. Bouma, W. R. Normak and N. E. Barnes (New York, NY: Springer), 15-22.

Striegl, R. G., Aiken, G. R., Dornblaser, M. M., Raymond, P. A., and Wickland, K. P. (2005). A decrease in discharge-normalized DOC export by the Yukon River during summer through autumn. Geophys. Res. Lett. 32:L21413. doi: 10.1029/2005GL024413

Stubbins, A., Hood, E., Raymond, P. A., Aiken, G. R., Sleighter, R. L., Hernes, P. J., et al. (2012a). Anthropogenic aerosols as a source of ancient dissolved organic matter in glaciers. Nat. Geosci. 5, 198-201. doi: 10.1038/ngeo1403

Stubbins, A., Niggemann, J., and Dittmar, T. (2012b). Photo-lability of deep ocean dissolved black carbon. Biogeosciences 9, 1661-1670. doi: 10.5194/bg-9-1661-2012

Stubbins, A., Spencer, R. G., Chen, H., Hatcher, P. G., Mopper, K., Hernes, P. J., et al. (2010). Illuminated darkness: molecular signatures of Congo River dissolved organic matter and its photochemical alteration as revealed by ultrahigh precision mass spectrometry. Limnol. Oceanogr. 55, 1467-1477. doi: 10.4319/lo.2010.55.4.1467

Subramaniam, A., Yager, P. L., Carpenter, E. J., Mahaffey, C., Björkman, K., Cooley, S., et al. (2008). Amazon River enhances diazotrophy and carbon sequestration in the tropical North Atlantic Ocean. Proc. Natl. Acad. Sci. U.S.A. 105, 10460-10465. doi: 10.1073/pnas.0710279105

Sundquist, E. T. (1993). The global carbon dioxide budget. Science 259, 934-934. doi: $10.1126 /$ science.259.5097.934

Syvitski, J., Burrell, D., and Skei, J. (1987). Fjords: Processes and Products. New York, NY: Springer-Verlag.

Takahashi, T., Sutherland, S. C., Wanninkhof, R., Sweeney, C., Feely, R. A., Chipman, D. W., et al. (2009). Climatological mean and decadal change in surface ocean $p \mathrm{CO}_{2}$, and net sea-air $\mathrm{CO}_{2}$ flux over the global oceans. Part II Top. Stud. Oceanogr. 56, 554-77. doi: 10.1016/j.dsr2.2008. 12.009

Tank, J. L., Rosi-Marshall, E. J., Griffiths, N. A., Entrekin, S. A., and Stephen, M. L. (2010). A review of allochthonous organic matter dynamics and metabolism in streams. J. North Am. Benthol. Soc. 29, 118-146. doi: 10.1899/08-170.1

Tehrani, N. C., D'Sa, E. J., Osburn, C. L., Bianchi, T. S., and Schaeffer, B. A. (2013). Chromophoric dissolved organic matter and dissolved organic carbon from sea-viewing wide field-of-view sensor (SeaWiFS), Moderate Resolution Imaging Spectroradiometer (MODIS) and MERIS Sensors: case study for the Northern Gulf of Mexico. Remote Sens. 5, 1439-1464. doi: 10.3390/rs5031439

Thorp, J. H., Thoms, M. C., and Delong, M. D. (2006). The riverine ecosystem synthesis: biocomplexity in river networks across space and time. River Res. Appl. 22, 123-147. doi: 10.1002/rra.901

Tierney, J. E., and Tingley, M. P. (2014). A Bayesian, spatially-varying calibration model for the TEX 86 proxy. Geochim. Cosmochim. Acta 127, 83-106. doi: 10.1016/j.gca.2013.11.026

Tockner, K., Pennetzdorfer, D., Reiner, N., Schiemer, F., and Ward, J. V. (1999). Hydrological connectivity, and the exchange of organic matter and nutrients in a dynamic river-floodplain system (Danube, Austria). Freshw. Biol. 41, 521-535. doi: 10.1046/j.1365-2427.1999.00399.x

Torn, M. S., Trumbore, S. E., Chadwick, O. A., Vitousek, P. M., and Hendricks, D. M. (1997). Mineral control of soil organic carbon storage and turnover. Nature 389, 170-173. doi: 10.1038/38260

Toth, J. (1963). A theoretical analysis of groundwater flow in small drainage basins. J. Geophys. Res. 68, 4795-4812. doi: 10.1029/JZ068i016p04795

Tranvik, L. J., and Bertilsson, S. (2001). Contrasting effects of solar UV radiation on dissolved organic sources for bacterial growth. Ecol. Lett. 4, 458-463. doi: 10.1046/j.1461-0248.2001.00245.x

Tranvik, L. J., Downing, J. A., Cotner, J. B., Loiselle, S. A., Striegl, R. G., Ballatore, T. J., et al. (2009). Lakes and reservoirs as regulators of carbon cycling and climate. Limnol. Oceanogr. 54, 2298-2314. doi: 10.4319/lo.2009.54.6_part_2.2298

Twilley, R. R. (1985). The exchange of organic carbon in basin mangrove forests in a southwest Florida estuary. Estuar. Coast. Shelf Sci. 20, 543-557. doi: 10.1016/0272-7714(85)90106-4

Utsumi, M., Nojiri, Y., Nakamura, T., Nozawa, T., Otsuki, A., Takamura, N., et al. (1998). Dynamics of dissolved methane and methane oxidation in dimictic Lake Nojiri during winter, Limnol. Oceanogr. 43, 10-17. doi: 10.4319/lo.1998.43.1.0010

Vannote, R. L., Minshall, G. W., Cummins, K. W., Sedell, J. R., and Cushing, C. E. (1980). The river continuum concept. Can. J. Fish. Aquat. Sci. 37, 130-137. doi: 10.1139/f80-017

van Verseveld, W. J., McDonnell, J. J., and Lajtha, K. (2009). The role of hillslope hydrology in controlling nutrient loss. J. Hydrol. 367, 177-187. doi: 10.1016/j.jhydrol.2008.11.002

Vieublé Gonod, L., Jones, D. L., and Chenu, C. (2006). Sorption regulates the fate of the amino acids lysine and leucine in soil aggregates. Eur. J. Soil Sci. 57, 320-329. doi: 10.1111/j.1365-2389.2005.00744.x

Vitousek, P., Mooney, H., Lubchenco, J., and Melillo, J. (1997). Human domination of Earth's ecosystems. Science 277, 494-499. doi: 10.1126/science.277.5325.494

Vodacek, A., Hoge, F. E., Swift, R. N., Yungel, J. K., Peltzer, E. T., and Blough, N. V. (1995). The use of in situ and airborne fluorescence measurements to determine UV absorption coefficients and DOC concentrations in surface waters. Limnol. Oceanogr. 40, 411-415. doi: 10.4319/lo.1995.40.2.0411

Walinsky, S., Prahl, F., Mix, A., Finney, B., Jaeger, J., and Rosen, G. (2009). Distribution and composition of organic matter in surface sediments of coastal Southeast Alaska. Cont. Shelf Res. 29, 1565-1579. doi: 10.1016/j.csr.2009.04.006

Walsh, J. J. (1988). On the Nature of Continental Shelves. San Diego, CA: Academic.

Ward, J. V., and Stanford, J. A. (1995). The serial discontinuity concept: extending the model to floodplain rivers. Regul. Rivers 10, 159-168. doi: 10.1002/rrr.3450100211

Ward, N. D., Bianchi, T. S., Sawakuchi, H. O., Gagne-Maynard, W., Cunha, A. C., Brito, D. C., et al. (2016). The reactivity of plant-derived organic matter and the potential importance of priming effects in the lower Amazon River. J. Geophys. Res. Biogeosci. 121, 1522-1539. doi: 10.1002/2016jg003342

Ward, N. D., Keil, R. G., Medeiros, P. M., Brito, D. C., Cunha, A. C., Dittmar, T., et al. (2013). Degradation of terrestrially derived macromolecules in the Amazon River. Nat. Geosci. 6, 530-533. doi: 10.1038/ngeo1817

Ward, N. D., Krusche, A. V., Sawakuchi, H. O., Brito, D. C., Cunha, A. C., Moura, J. M. S., et al. (2015). The compositional evolution of dissolved and particulate organic matter along the lower Amazon River-Óbidos to the ocean. Mar. Chem. 177, 244-256. doi: 10.1016/j.marchem.2015.06.013

Ward, N. D., Richey, J. E., and Keil, R. G. (2012). Temporal variation in river nutrient and dissolved lignin phenol concentrations and the impact of storm events on nutrient loading to Hood Canal, Washington, USA. Biogeochemistry 111, 629-645. doi: 10.1007/s10533-012-9700-9

Waterloo, M. J., Oliveira, S. M., Drucker, D. P., Nobre, A. D., Cuartas, L. A., Hodnett, M. G., et al. (2006). Export of organic carbon in run-off from an amazonian rainforest blackwater catchment. Hydrol. Process. 20, 2581-2259. doi: 10.1002/hyp. 6217

Waterson, E. J., and Canuel, E. A. (2008). Sources of sedimentary organic matter in the Mississippi River and adjacent Gulf of Mexico as revealed by lipid biomarker and $\delta 13$ C TOC analyses. Org. Geochem. 39, 422-439. doi: 10.1016/j.orggeochem.2008.01.011

Webb, R. S., and Webb, T. (1988). Rates of sediment accumulation in pollen cores from small lakes and mires of eastern North America. Q. Res. 30, 284-297. doi: 10.1016/0033-5894(88)90004-X

Wehrli, B. (2013). Biogeochemistry: conduits of the carbon cycle. Nature 503, 346-347. doi: 10.1038/503346a

Weston, N. B., and Joye, S. B. (2005). Temperature-driven decoupling of key phases of organic matter degradation in marine sediments. Proc. Natl. Acad. Sci. U.S.A. 102, 17036-17040. doi: 10.1073/pnas.0508798102

Wetzel, R. G. (2001). Limnology-Lake and River Ecosystems, 3rd Edn. San Diego, CA: Academic

Wetzel, R. G., Hatcher, P. G., and Bianchi, T. S. (1995). Natural photolysis by ultraviolet irradiance of recalcitrant dissolved organic matter to simple substrates for rapid bacterial metabolism. Limnol. Oceanogr. 40, 1369-1380.

Whitehead, J. A. (1987). Dense water off continents. Nature 327. doi: $10.1038 / 327656 \mathrm{a} 0$

Whitehead, P. G., Wilby, R. L., Battarbee, R. W., Kernan, M., and Wade, A. J. (2009). A review of the potential impacts of climate change on surface water quality. Hydrol. Sci. J. 54, 101-112. doi: 10.1623/hysj.54.1.101

Wilkinson, B. H., and McElroy, B. J. (2007). The impact of humans on continental erosion and sedimentation. Geol. Soc. Am. Bull. 119, 140-156. doi: 10.1130/B25899.1 
Wollast, R. (1998). "Evaluation and comparison of the global carbon cycle in the coastal zone and in the open ocean," in The Sea, Vol. 10, eds K. H. Brink and A. R. Robinson (New York, NY: Wiley), 213-252.

Woodwell, G. M., Rich, P. H., and Hall, C. A. S. (1973). "Carbon in estuaries," in Carbon and the Biosphere, eds G. M. Woodwell and E.V. Pecan (Springfield: U.S. Atomic Commision), 221-240.

Wysocki, L. A., Bianchi, T. S., Powell, R. T., and Reuss, N. (2006). Spatial variability in the coupling of organic carbon, nutrients, and phytoplankton pigments in surface waters and sediments of the Mississippi River plume. Estuar. Coast. Shelf Sci. 69, 47-63. doi: 10.1016/j.ecss.2006.03.022

Zhai, W., Dai, M., and Guo, X. (2007). Carbonate system and $\mathrm{CO}_{2}$ degassing fluxes in the inner estuary of Changjiang (Yangtze) River, China. Mar. Chem. 107, 342-356. doi: 10.1016/j.marchem.2007.02.011

Zimmerman, A. R., and Canuel, E. A. (2002). Sediment geochemical records of eutrophication in the mesohaline Chesapeake Bay. Limnol. Oceanogr. 47, 1084-1093. doi: 10.4319/lo.2002.47.4.1084
Zonneveld, K. A. F., Versteegh, G. J. M., Kasten, S., Eglinton, T. I., Emeis, K. C., Huguet, C., et al. (2010). Selective preservation of organic matter in marine environments; processes and impact on the sedimentary record. Biogeosciences 7, 483-511. doi: 10.5194/bg-7-483-2010

Conflict of Interest Statement: The authors declare that the research was conducted in the absence of any commercial or financial relationships that could be construed as a potential conflict of interest.

Copyright (๑ 2017 Ward, Bianchi, Medeiros, Seidel, Richey, Keil and Sawakuchi. This is an open-access article distributed under the terms of the Creative Commons Attribution License (CC BY). The use, distribution or reproduction in other forums is permitted, provided the original author(s) or licensor are credited and that the original publication in this journal is cited, in accordance with accepted academic practice. No use, distribution or reproduction is permitted which does not comply with these terms. 